Historic, Archive Document

Do not assume content reflects current scientific knowledge, policies, or practices. 



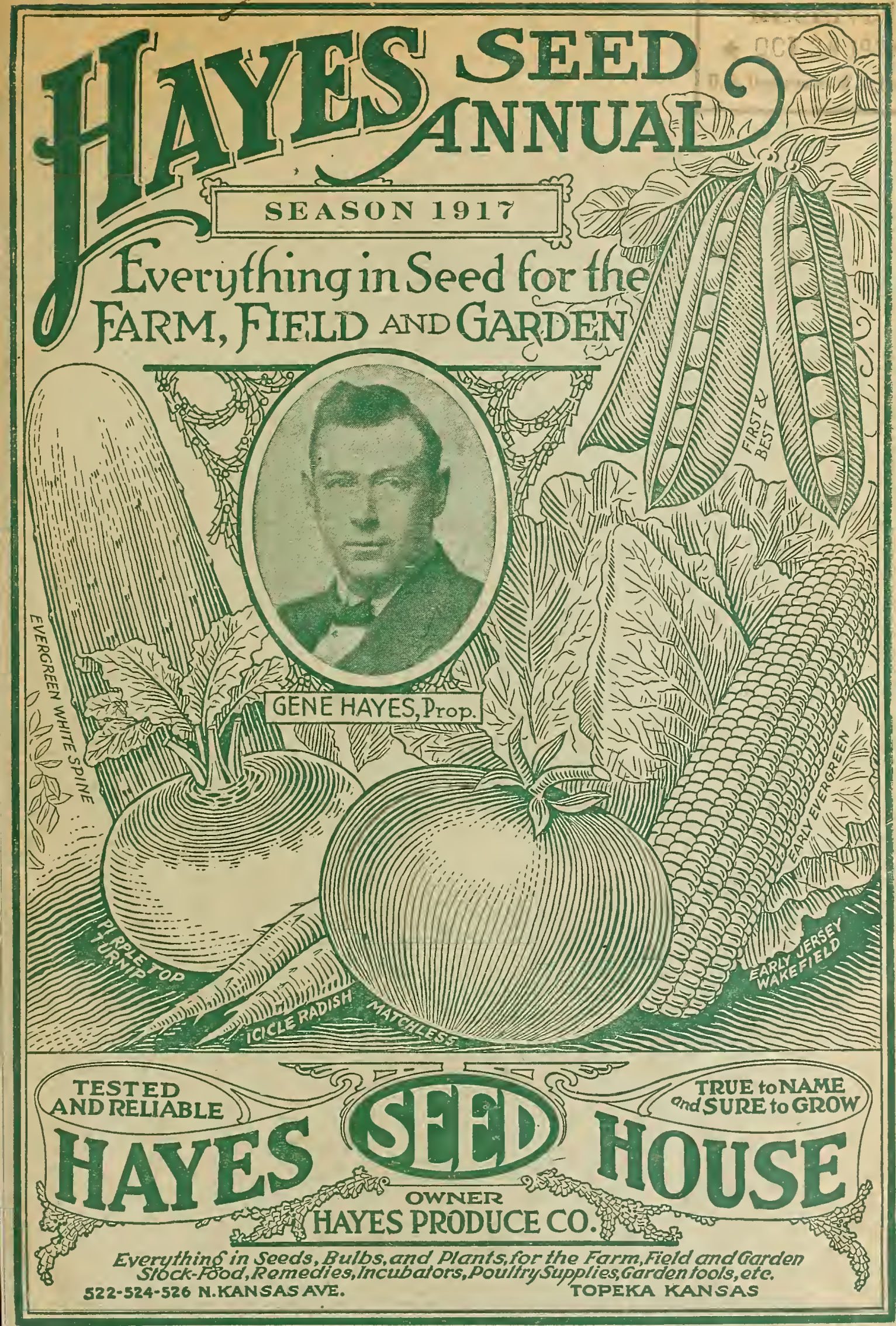

SEND US A TRIAL ORDER TODAY 


\section{Market Gardener's Price List}

We desire to offer to the MARKET GARIDNERS and SEED BTYERS our SEED AN. $N L^{\circ}-1 L$. The seeds herein quoted embrace all the best varieties, and is issued to meet the needs of the PLANTERS in every market gardening section. East, Nest, North and South our position as MARKET GARDENERS SEEDSMAN is beeoming larger earh succeeding season, and now embraees more than 25,000 Planters through the country.

Our reputation has been built up by furnishing seeds of the best quality as to purity and germination, and we shall always endeavor to furnish THE BEST SEEDS that can be procured, and make prices as reasonable as possible.

PRICEs
On some lines are going to be high,
such as Garden Beans, Spinach, Seed
Corn and Onion Sets.
Prices on Field and Grass Seeds
are very reasonable, quality is very
fine.

We are in a position to furnish good seeds at as low figures as any reliable house. We can and will meet all prices made by any one offering goods of equal value with ours, but we have no ambition to compete with those offering inferior stocks.

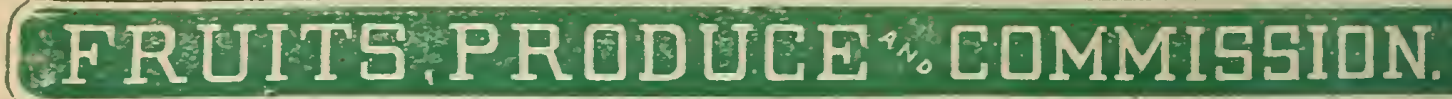

\section{In This Department}

We handle all kinds of Early Fruits and Vegetables, such as Berries, Peaches, Pears, Apples, etc.; Tomatoes, Radishes, Lettuce, Green Beans, Cabbage, Potatoes, Onions, etc. WE ARE THE LARGEST DEALERS IV TITERMELONS in the Central United States. Let us hear from rou when you have anything to offer or want to buy.

We buy all kinds of Seeds and Grain, send us liberal samples for test and grade, of what you have, to offer.

\section{Reference:}

\section{Shawnee State Bank}

Bonded under the laws of the State of Kansas.

We carry United States Produce Merchants' License.

\section{FANCY POULTRY}

In this department jou will find listed on pages 32 and 33 more than 50 varities. Look this over.

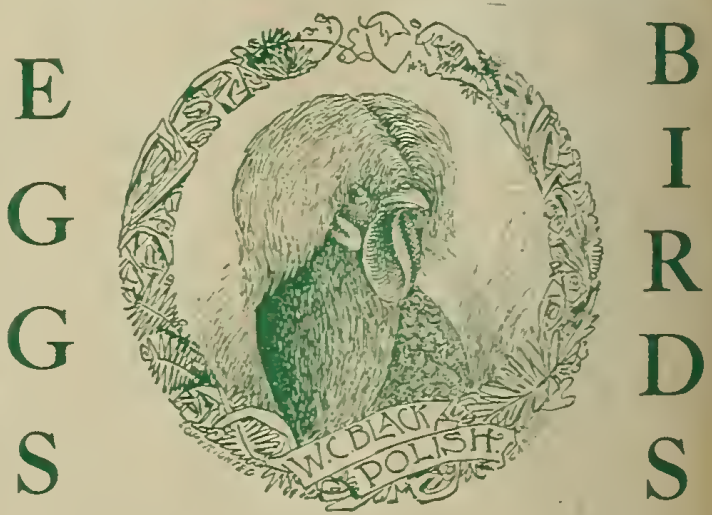

For Sale at Reasonable Prices 


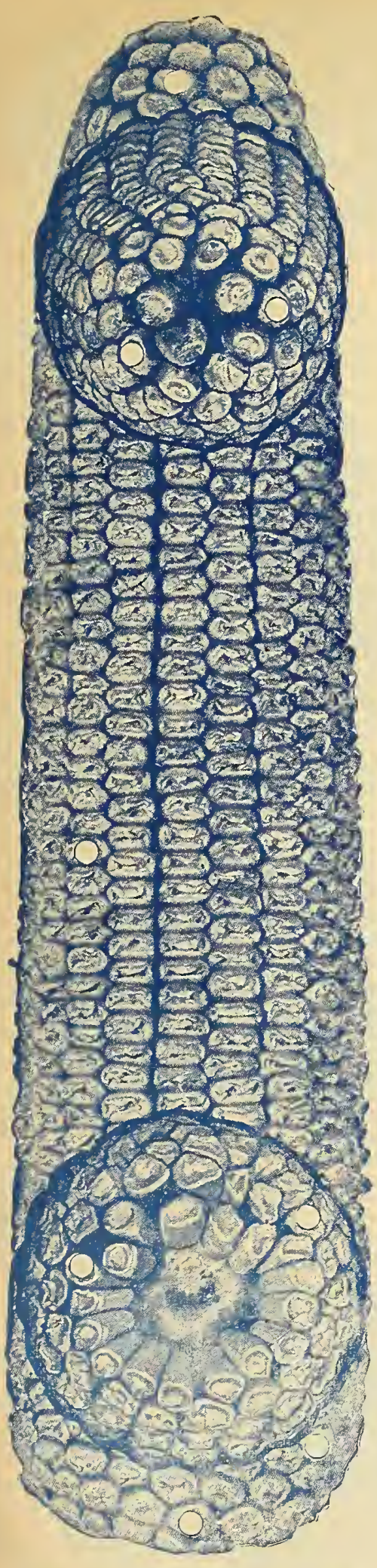

DIAMOND JOE'S BIG WHITE.

\section{SEED CORN}

of the

\author{
BEST QUALITY KANSAS GROWN.
}

At no time in the history of American agriculture has it been so necessary to secure maximum returns from farming as at the present, and there is no erop the farmer raises that will give increased returns in proportion to care in seed selection as CORN.

One grain of corn will produce MORE CORN than a similar quantity of any other cereal will produce of its kind. PLANT GOOD SEED. We have it, at reasonable prices, selected and graded seed, tips and butts off.

We grow and contract for our corn with the best corn growers in this state and they have received First Prize Money at the Kansas State Fair and other Corn Exhibits. Our prices are reasonable and we hope to get your order early. Let us book it NOW and we will ship when you are ready for it.

SPECIAI-If you expect to buy seed corn this year, let us know. We will send you FREF of charge, SAMPLES of any kinds you want, and the corn will be just as the samples are we send you, or you ship it back to us and we will refund your IMONEY. We offer you as follows:

\section{DIAIVIOND JOE'S BIG WHITE (EARLY).}

was brought into our home county (Shawnee), three years ago from Iowa, and it has became thoroughly acclimated with our climatic conditions and our crop this year will average 80 bushels per acre, and everywhere tried and tested, north, south, east and west, it has proven a wonderful success, producing enormous yields and maturing as early as the earliest varieties of big white corn.

DESCRIPTION:--Stalks are large, strong and robust, growing to a height of 8 to 12 feet, dependent upon the land; a great drouth resister; broad blades and many of them; ears 8 to 12 inches long and 7 to 8 inches in circumference; 16 to $20 \mathrm{rows}$, deep grains, solidly set on a medium size cob; cobs white, matures in about 100 days, every stalk producing one to three good ears. It is not only adapted to good, strong ground, but will do better and return larger yields on old, poor, thin or hilly ground than any other variety in existence. In short, it is the embodiment of all the good qualities contained in all the best varieties. It's the sure thing-all we claim for it. Our seed stock of this corn is exceptionally fine this year (extra choice), having been grown from absolutely pure seed stock, and we have made a selection of the most choice ears, and hope to be able to fill every order promptly that comes to us this year. Price per single bushel, $\$ 2.50$. 


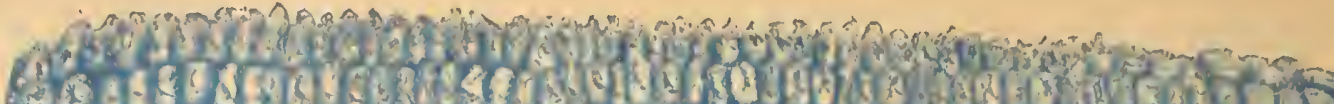 ench secoum (x)

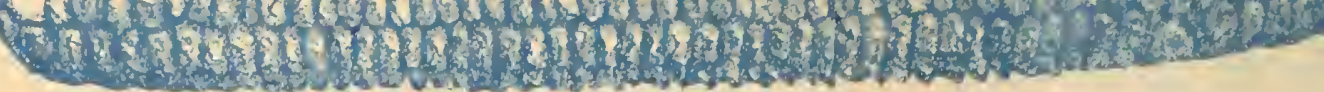

\author{
BOONE COUNTY WHITE
}

DESCRIPTION-Ears well fillcd out at both cnds. cylindrical, 9 to 11 inches 'ong, averaging 20 rows, some 18 and 22. Grain very deep, a little rough. Cobs white, of medium sizc. Boone County is a show corn, and has carried off many premiums offered at corn contests-state and county fairs. Matures in 110 to 120 days. Price, per single bushel, $\$ 2.50$.

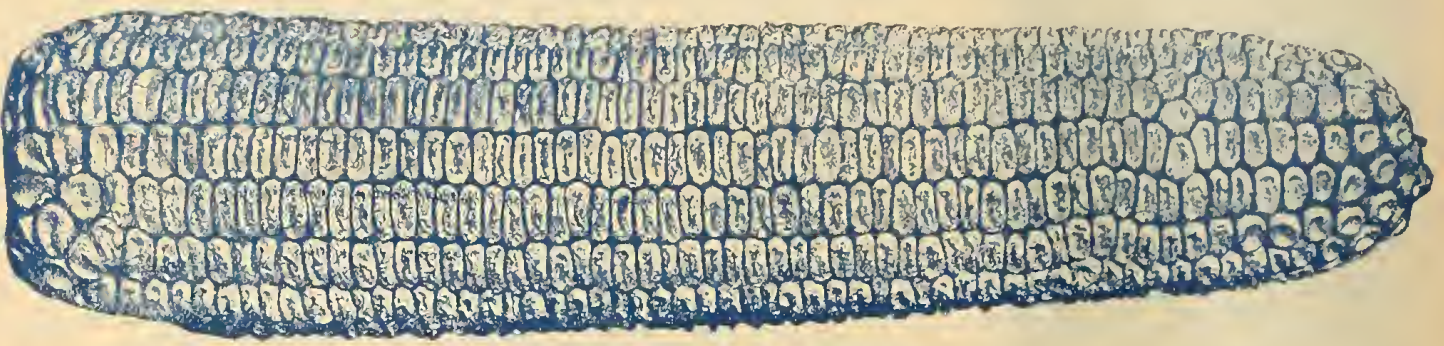

IOWA SILVER MINE.

DESCRIPTION-Silver Mine is deep grained, purc white, rough-topped, with a small white cob. Ears 9 to 12 inches long, 16 to 20 rows of pure white kernels, solidly set on ears well. filled at butt and tip. The small cob dries out rapidly and can be marketed early. This corn is a drouth resister. Frequently bearing two ears weighing 1 to $1 \frac{1 / 2}{2}$ pounds each. Maturcs in 100 days. Price, per single bushel, \$2.50, shelled and graded.

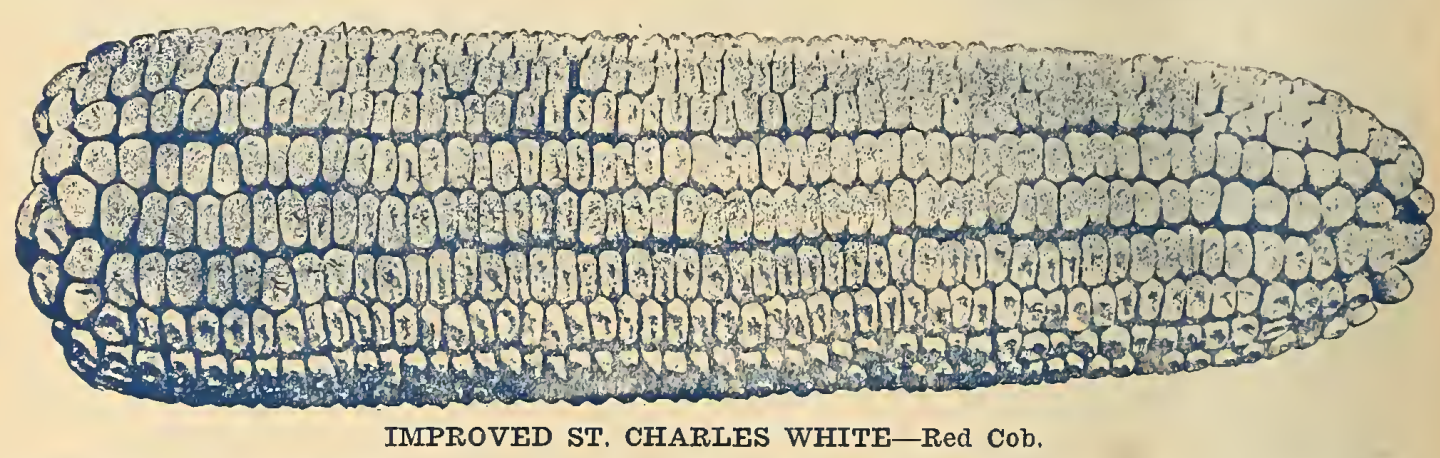

DESCRIPTION-Pure white corn with red cob, ears are large, moderately rough, deep grain. Stalks grow very leafy and heavy, and will produce enormous viclds of corn. Matures in 100 days. Pricc, per single bushel, $\$ 2.50$, shelled and graded.

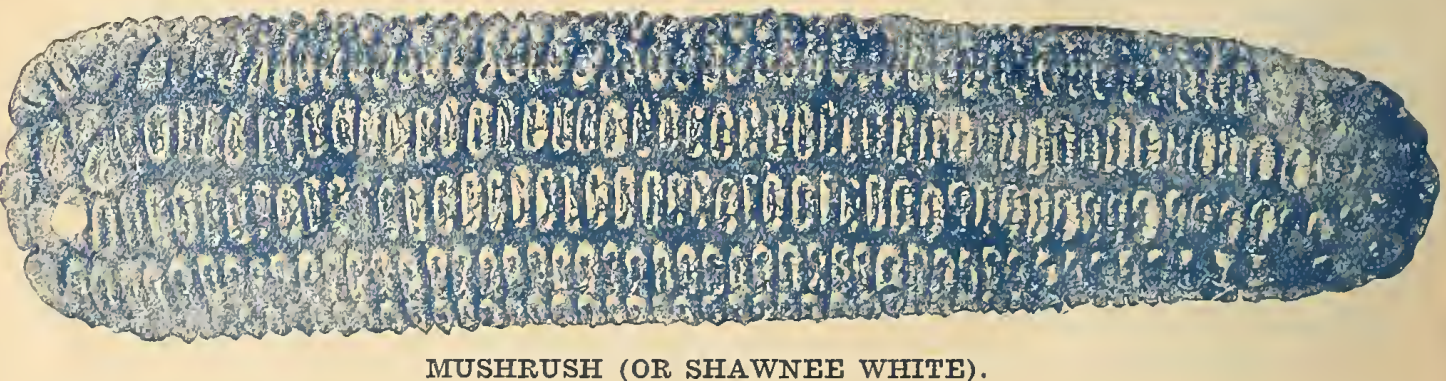

One of the largest eared white corn grown. grains dented, broad and fairly smooth, ears 10 to 14 inches long, matures 110 to 120 days. A drouth resister, well adapted to upland, as well as bottom. Price, per single bush-
el, $\$ 2.50$, shelled and graded. 


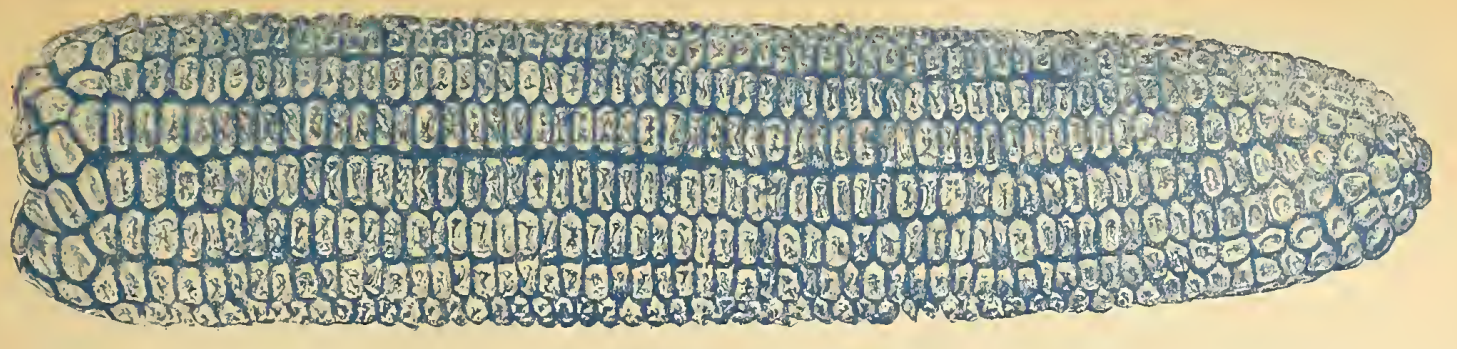

REID'S YEILOW DENT.

DESCRIPTION-Color deep yellow, with lighter cap. Grain very deep, closely packed; butts and tips almost entirely covered over. Slightly rough, with grains dented on top. Leaves and stalls of Reid's Yellow Dent make the finest ensilage and fodder. Matures in about 90 days. Price, per single bushel, $\$ 2.50$, shelled and graded.

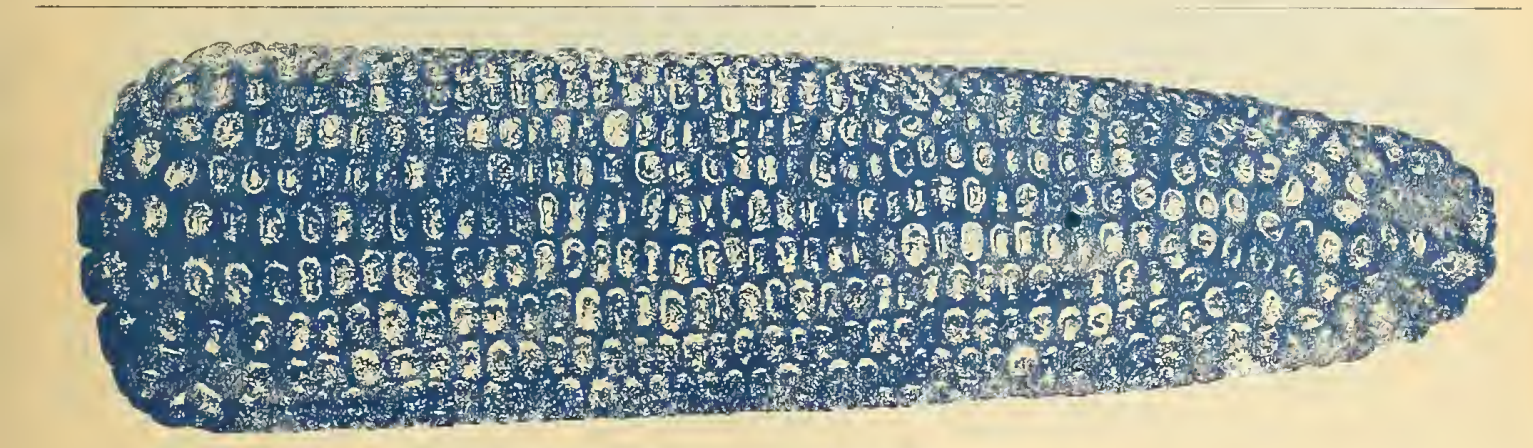

IMPROVED LEAMING.

A corn of very rich, deep-golden color; slightly tapering ear, well filled at the butt and tip. The ears range from 8 to 12 inches long and from 7 to 8 inches in circumference, weighing from 12 to 17 ounces each. Each ear has from 16 to 24 rows of kernels, which are broad, deep and thick. set on a red cob of medium size. Matures in about 90 days. Price, per single bushel, $\$ 2.50$, shelled and graded.

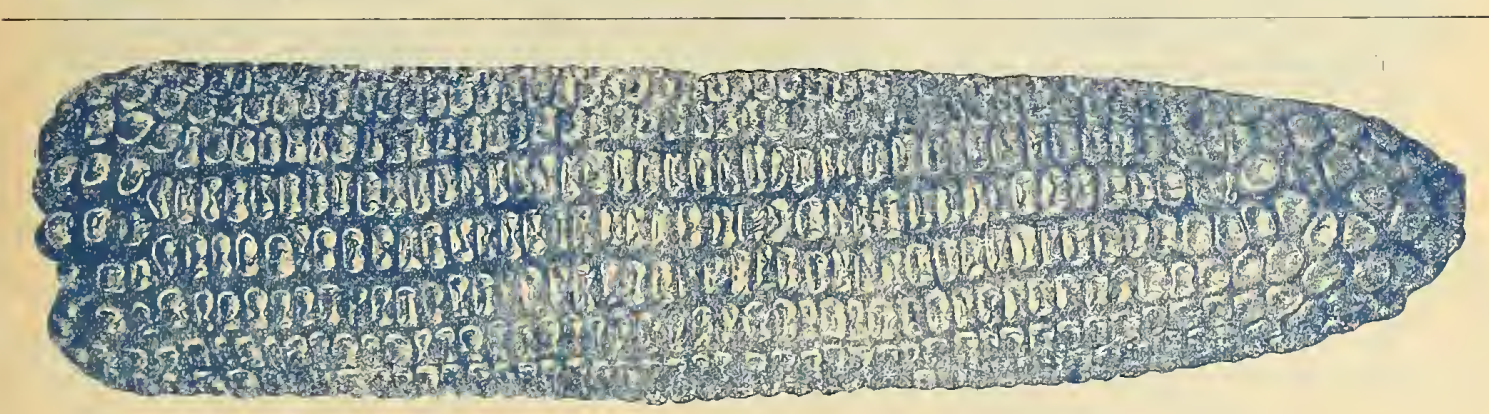

\section{HILDRETH YELLOW DENT.}

This corn is a very large growing variety. The ear is large and well rounded at butt and tip. The kernels are inclined to be small, but are very deep. Indentation medium rough; color deep golden yellow. Matures in 100 days. Price, per single bushel, \$2.50, shelled and graded.

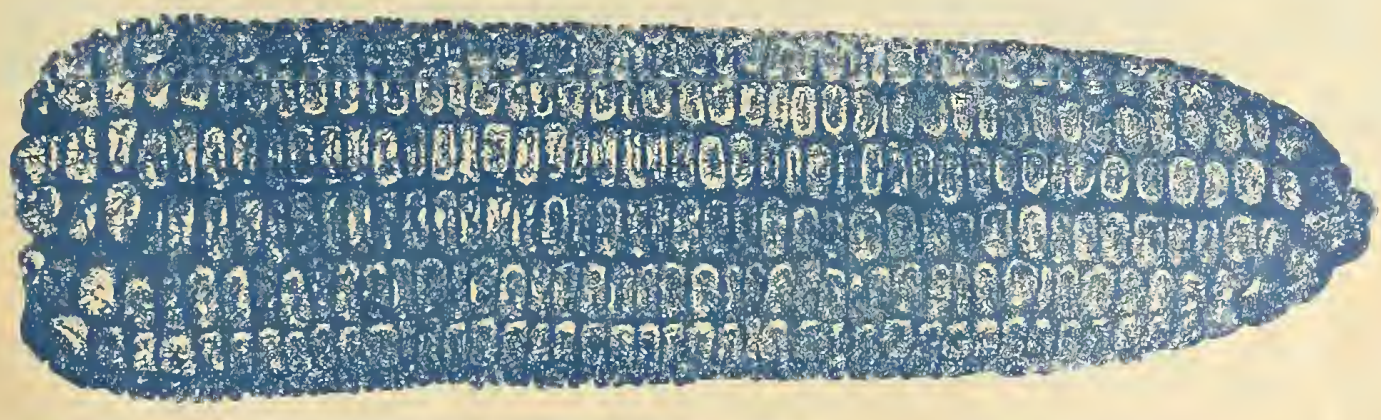

IOWA GOLD MINE.

A handsome early corn, ripening a sew days after our improved Leaming; ears are of good size, even and uniform in shape: cob smal wilh very deep grains of bright golden color. Matures in 100 days. Price. per single bushel, $\$ 2.50$, shelled and graded. 


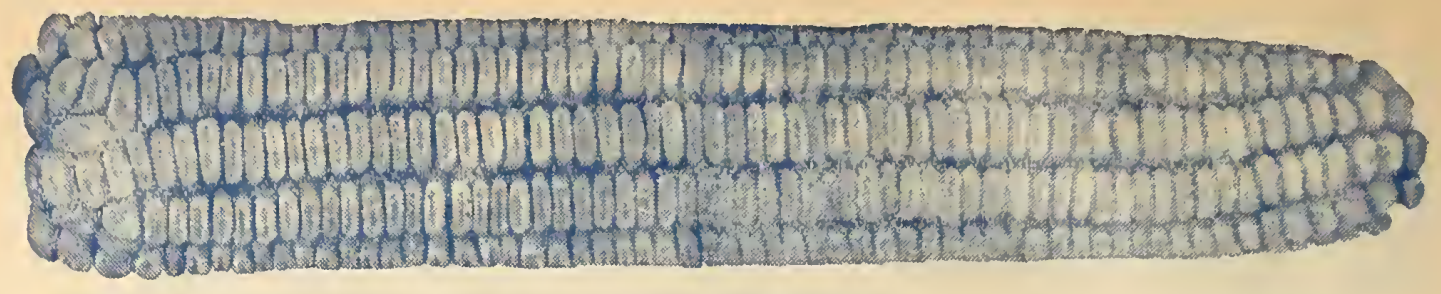

GOLDEN BEAUTY.

The ears are of perfect shape, with from ten to fourteen straight rows of bright golden yellow grains, remarkable in size and filled out completely to the extreme end of the cob The richness of color and fine auality of grain make it vastly superior for grinding and feeding. Matures in 100 days. Price, per single bushel, $\$ 2.50$, shelled and graded.

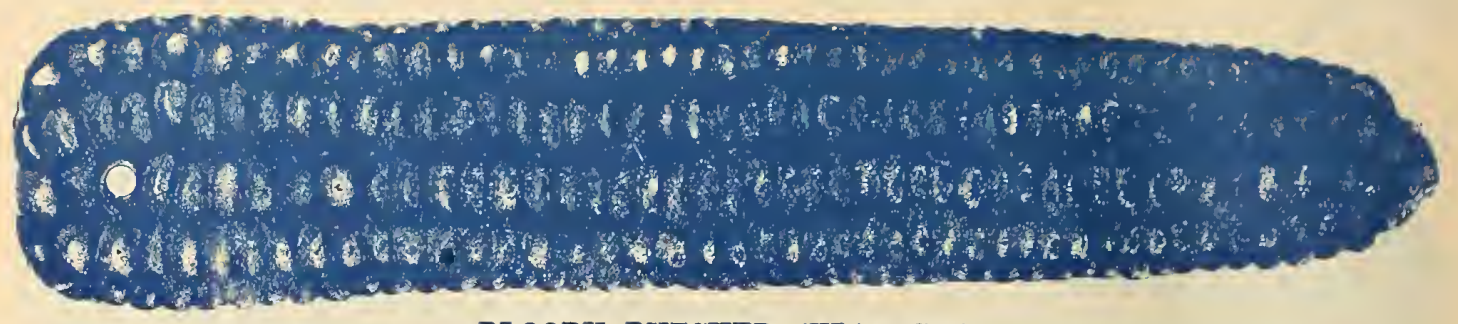

BLOODY BUTCHER (White Cap).

This corn is much sought after by the farmer who finds it necessary to replant his corn in June or July. Is a good yielder, making as high as 65 bushels to the acre.

DESCRIPTION-Color deep cherry-red with white cap, generally 14 rows of pure red white cap corn on a small cob. Long, slender ears 10 to 12 inches. Stalks medium height, fairly heavy, grains always dented and sometimes rough. Matures in about 80 days. Price, per single bushel, $\$ 2.50$, shelled and graded.

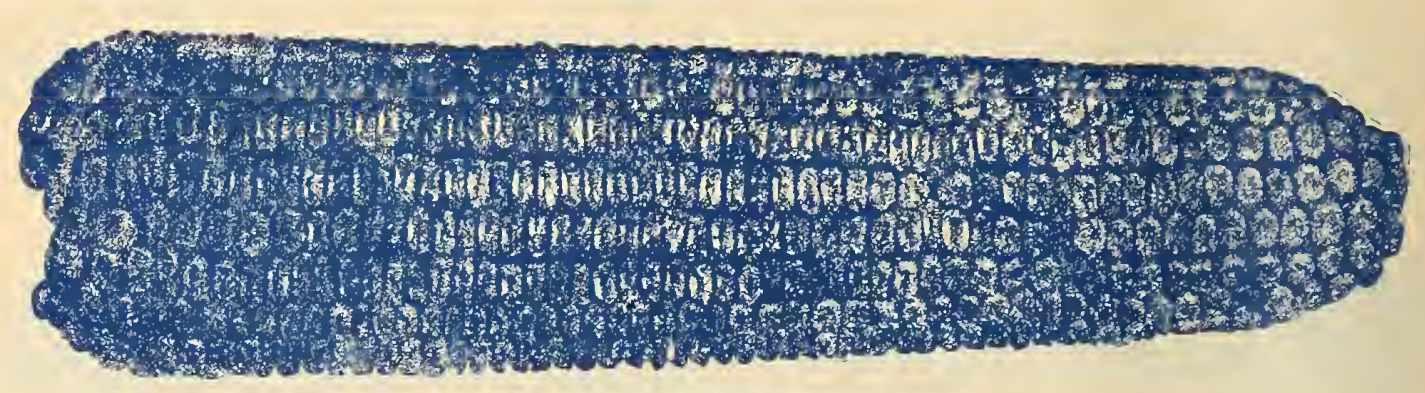

CALICO OR STRAWBERRY CORN.

old Fashloned Red, White and Yellow.

DESCRIPTION-This peculiarly colored corn is obtained by breeding together strong, vigorous red, white and yellow types of rich feeding stock, producing a kernel showing stripes of the three colors. Ears large, deep grain and small cob, 9 to 12 inches in length, and 7 to 8 inches in circumference. Matures in about 90 days. Price, per single bushel, $\$ 2.50$, shelled and graded.

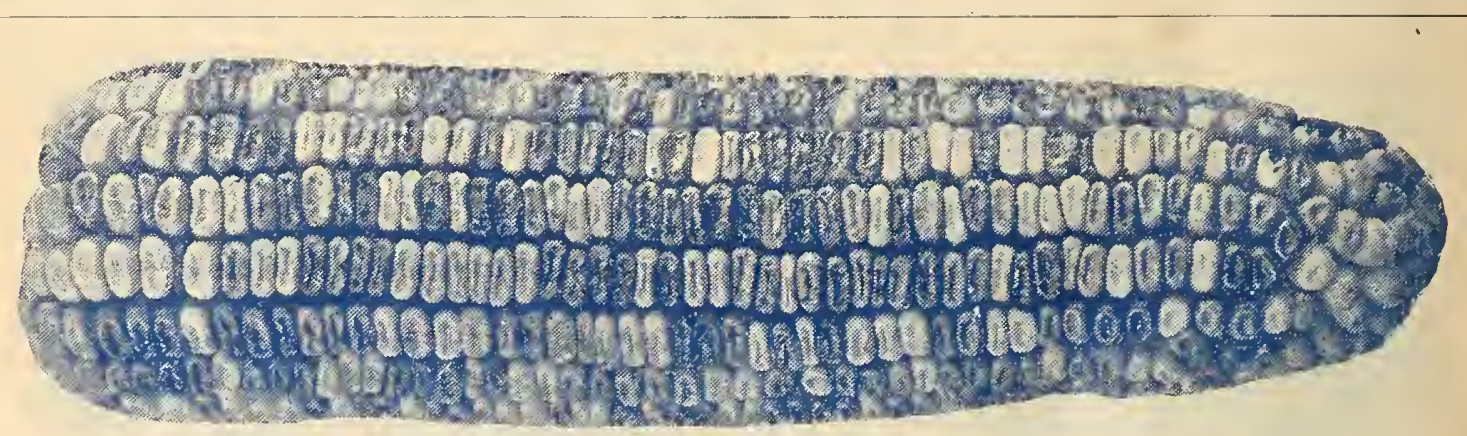

IMPROVED INDIAN SQUAW CORN.

Holds more records for wonderful performances uncer difficult conditions than any corn ever grown.

It has an extremely early variety, maturing in 85 days. Perhaps the most wonderful quality of this corn is its power to resist drouth, and it does equally as well in wet seasons. Fars large, 10 to 12 inches and two on every stalk. The kernels are of different colors. Bie pins and red and white, giving the ears a curious graded

\section{We Have the Best Seed Corn Grown}




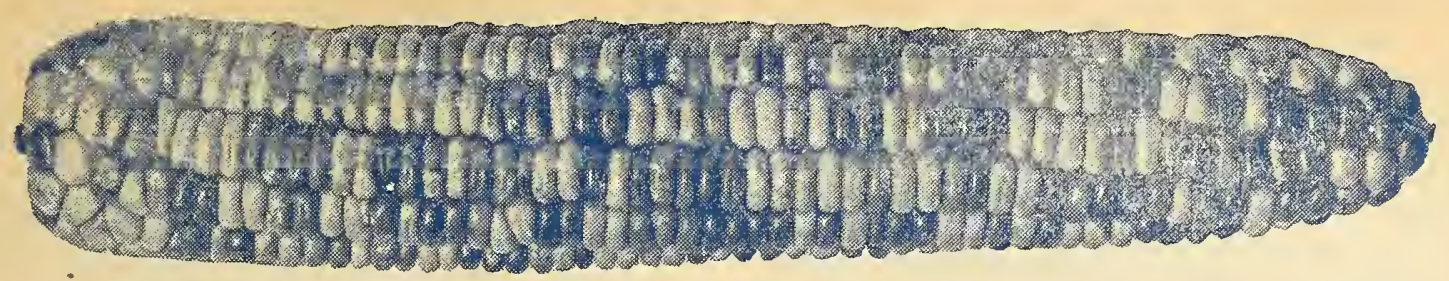

SEMI-FLINT SQUAW CORN.

Maturity 70 to 75 days. This is one of the very earliest field corns now grown and will outyield any of its kind, ears 12 to 16 inches long, 2 to 4 ears on a stalk. Grain medium deep and broad, fine for table use as well as feeding, and no better ensilage corn than it is. Price, per single bushel, $\$ 2.50$, shelled and graded.

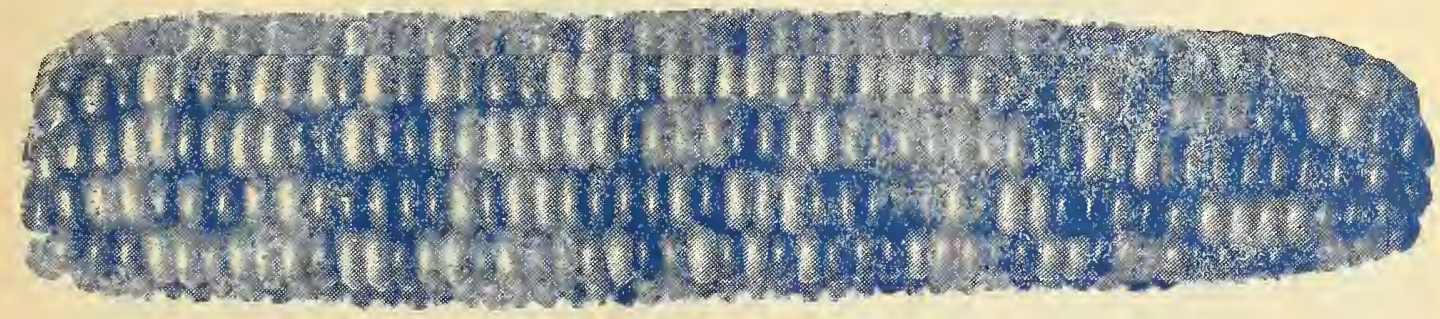

SQUAW CORN.

This is the old fashioned Flint Corn that is known by every one the country over as Squaw Corn. Matures in 75 days, has two to four large ears to the stalk, kernels blue and white, especially recommended where an early corn is needed for early stock feeding and for ensilage purposes. It can't be beat. Give this corn a trial and you will always have corn. Price, per single bushel, $\$ 2.50$, shelled and graded.

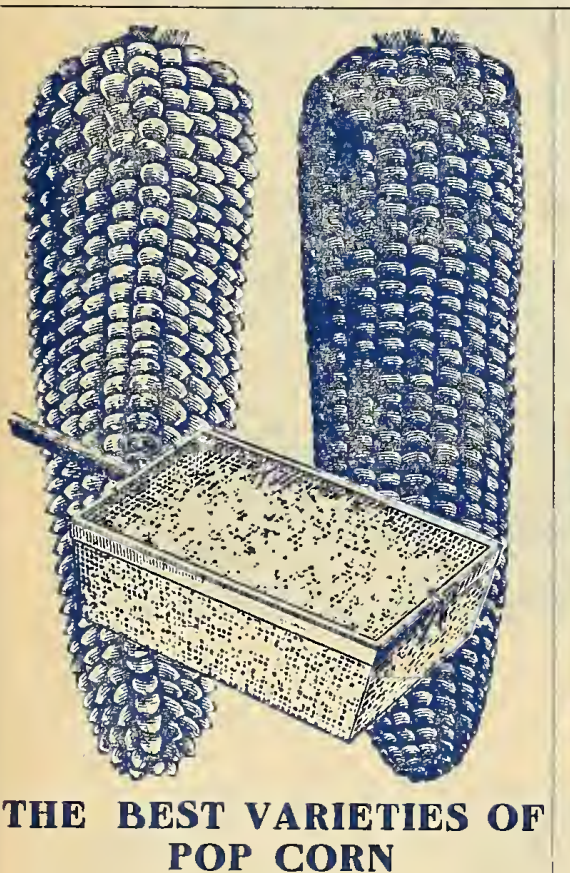

RICE.

A very productive variety. Ears short. kernels long and pointed. A splendid popping sort, and the most salable among the retail dealers. Price, per pound, selected, $10 \mathrm{c}$; 3 for $25 \mathrm{c}$; postpaid. WHITE PEARL.

Smooth, small grain ears 6 or 9 inches long, seven-eighths to one and oneeighth inches in diameter. Price. per lb., $10 \mathrm{c}$; 3 for $25 \mathrm{c}$; postpaid.

\section{GOLDEN QUEEN.}

Ears of large size, and the kernels pop to over an inch in diameter. One of the best and most prolific varieties grown. Price, per lb., 10c; 3 for $25 \mathrm{c}$; postpaid.

NOTE-We will contract for all the Pop Corn you have or will make contract for growing. Write us.

\section{TOWNSENDS}

\section{Day Yellow Dent Corn}

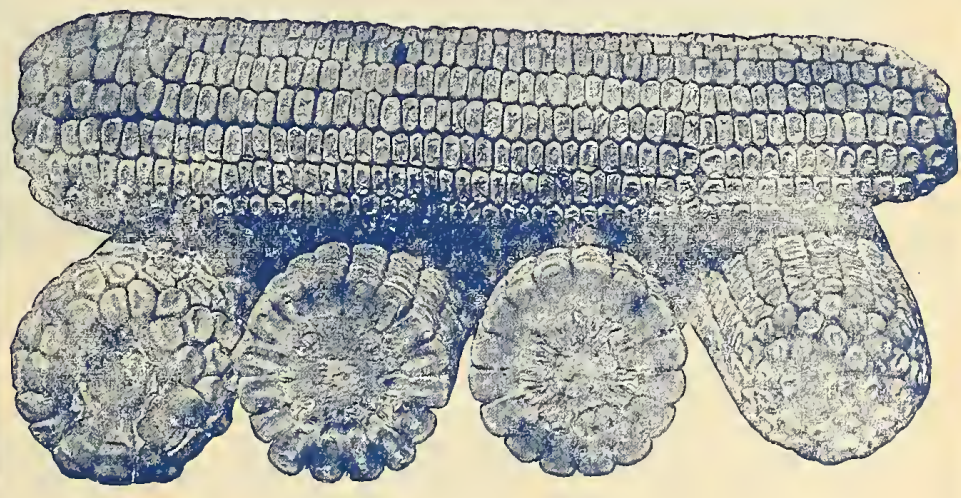

This grand NEW variety of EXTRA EARLY YELLOW DENT CORN was first introduced in this locality (Shawnee Co., Kansas) by Mr. A. Townsend, one of our leading farmers and stockmen. and is fast becoming a favorite corn where early feed is required. The ears are of handsome appearance, bearing 12 to 14 rows of bright, rich yellow, smooth wedge-shaped kernels, packed closely on a small red cob, from butt to tip. The ears average 8 inches in length and are borne usually two on a stalk. Townsend's Extra Early Yellow Dent is without an equal in the fields of early corn. Price, $1 / 4$ bushel, 75 cents; 1/2 bushel, $\$ 1.50$; per bushel, $\$ 2.50$. 


\section{Northern Grown Seed Potatoes}

On account of the scarcity of NORTHERN GROWN SELD POTATOES, we arc unable to quote you prices, but we will have all kinds to offer for the planting sea son, and we ask that you write us for PRICES soon as you are ready to plant. We can save you money on them and will give you prompt shipment.

WE WIII HAVE THE FOLTOWING VARIETIES AT LOWEST PRICES.

\section{Genuine Red River Ohio}

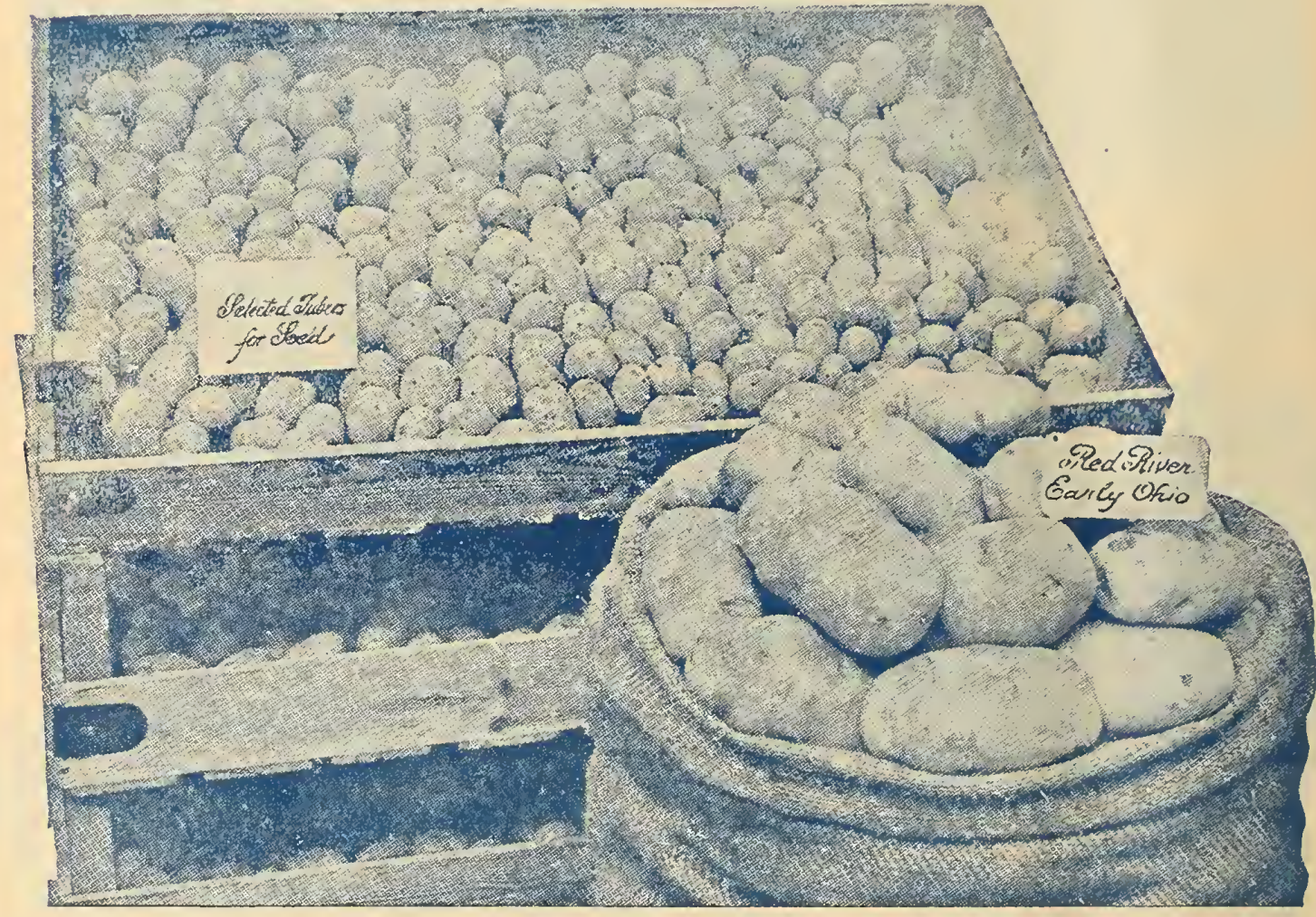

\section{Early Six Weeks}

This remarkably early Potato is especially valuable to the market gardener, and for those with a small garden who grow for extra early Potatoes only. It is ready for use ten days ahead of the Early Ohio; of excellent quality; abundant bearers and a good keeper. In shape it is identical with the Early Ohio; color much lighter; skin very smooth with few very shallow eyes. This should be planted largely and you will be well repaid with results. South Dakota sand land. Per bushel,

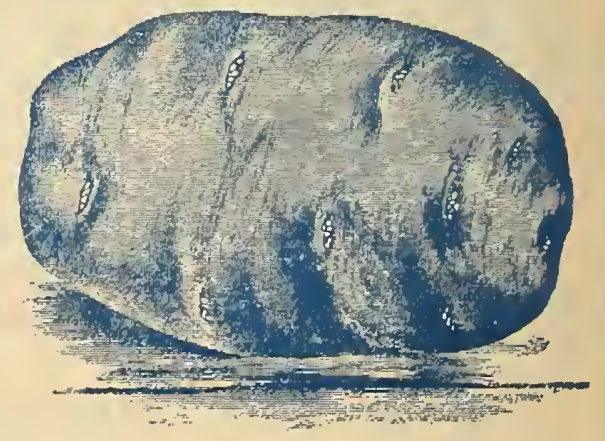




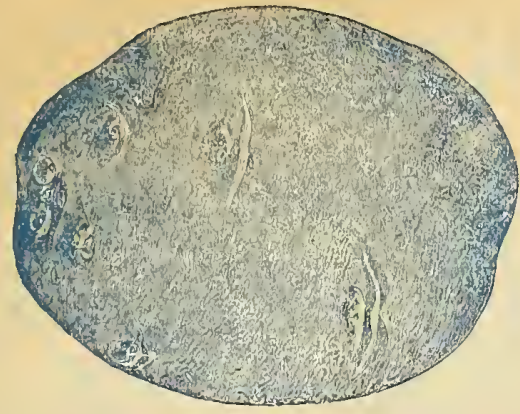

IRISH COBBLER.

Price, per bushel

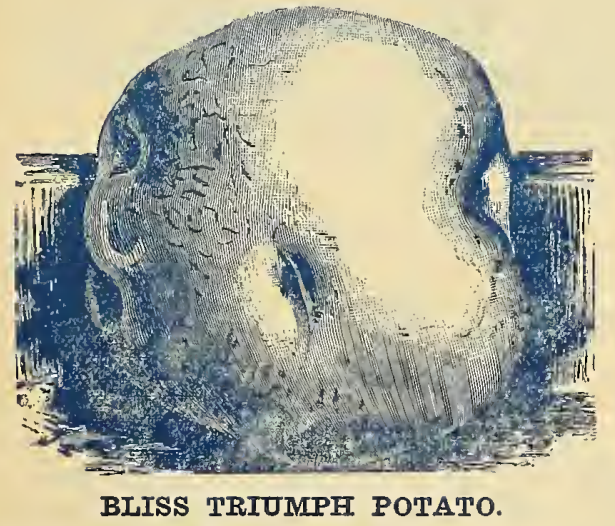

Price, per bushel

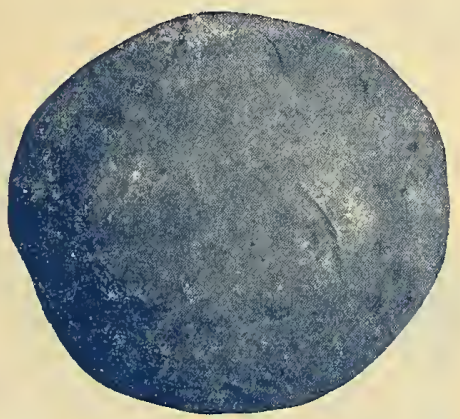

RURAL NEW YORKER No. 2.

Price, per bushel

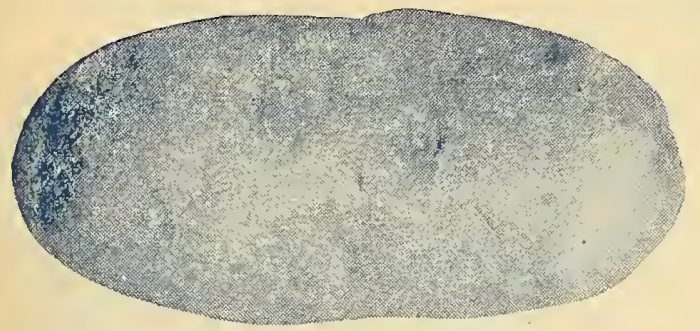

BURBANK.

Price, per bushel

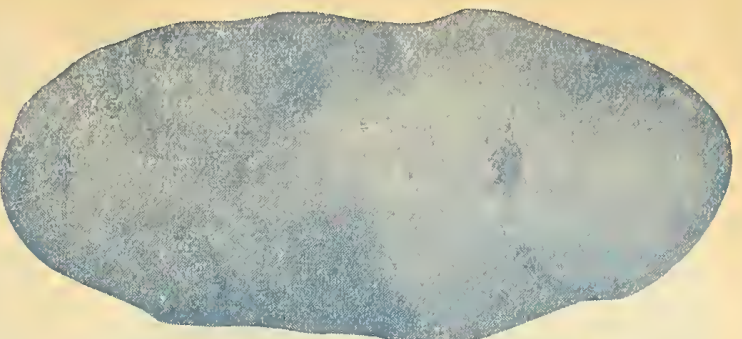

RUSSET, OR NETTED BURBANK.

Price, per bushel

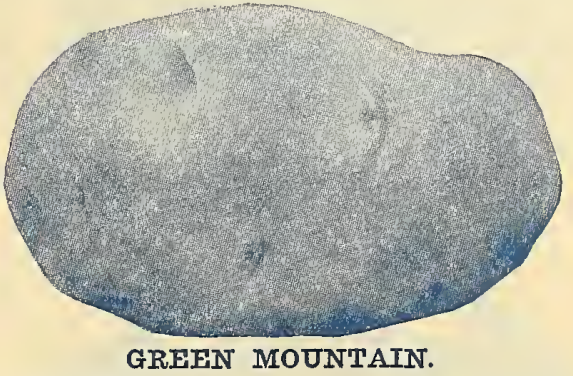

Price, per bushel $\ldots \ldots, \ldots, \ldots \ldots, \ldots \ldots \ldots \ldots$.

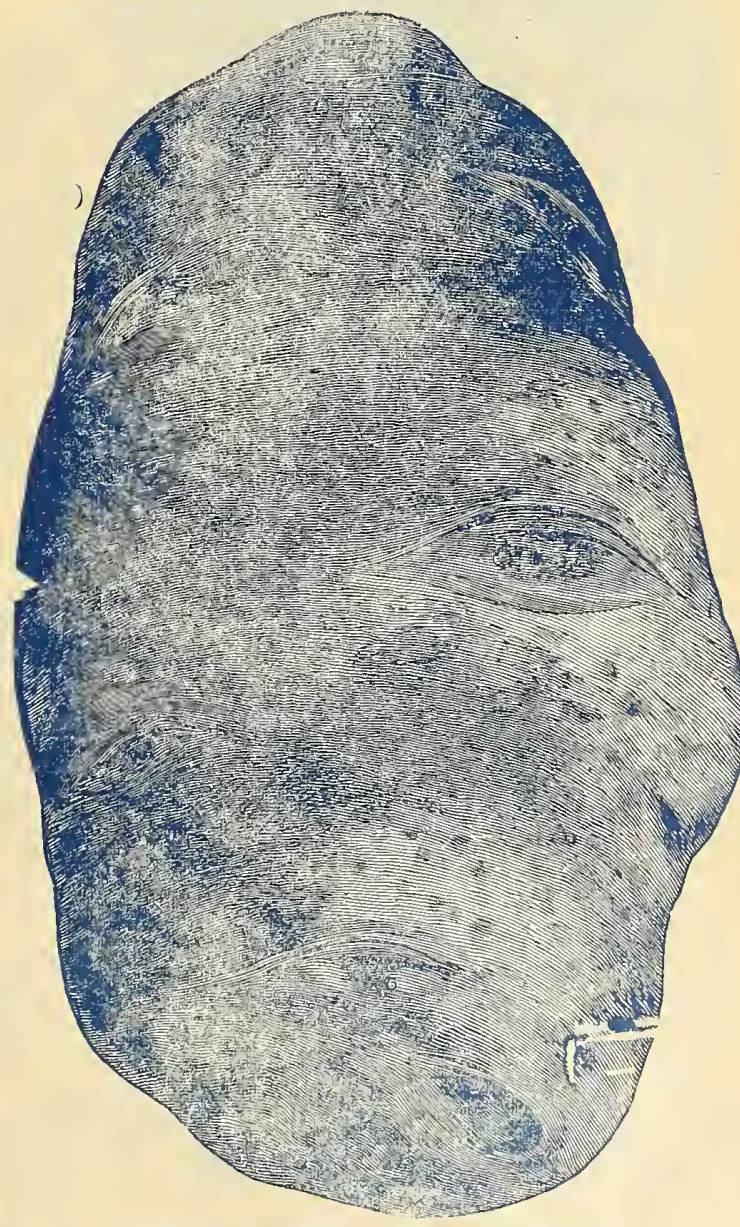

EARLY ROSE (Red RIVer Grown).

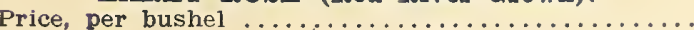




\section{SWEET POTATOES}

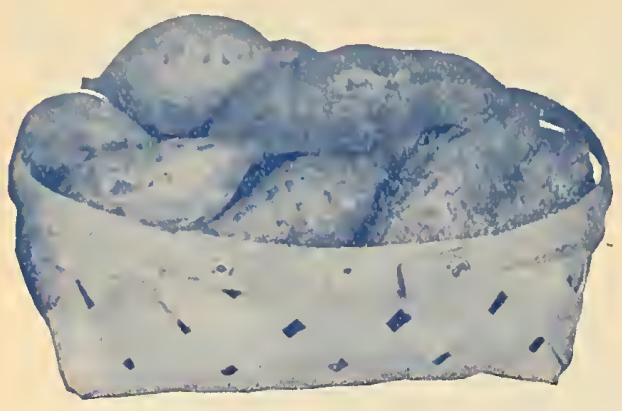

SOUTHERN QUEEN.

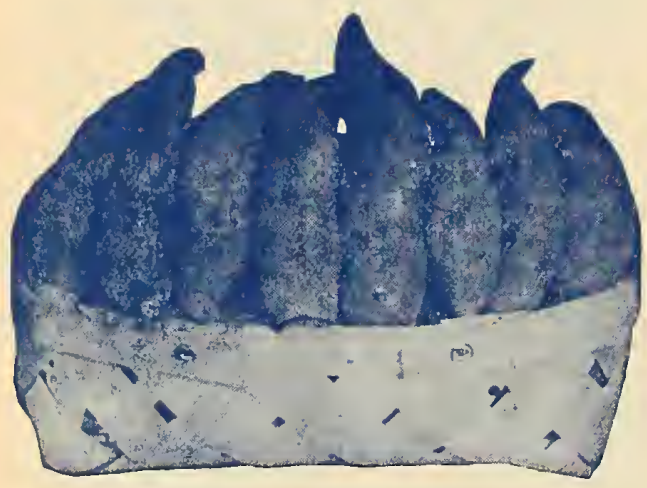

BLACK SPANISH.

VINELESS.

A good keeper and drouth resister; a good yielder and hardly any vines. Per bushel, $\$ 2.00$.

\section{PRIDE OF KANSAS.}

A large, yellow potato and good yielder. Per bushel, 50 pounds, $\$ 1.75$.

WHITE BRAZILIAN.

A large, white, late potato. Per bushel, 50 pounds, $\$ 1.75$.

\section{FARLY GOLDEN.}

A large, yellow potato, a good yielder. Per bushel, $\$ 2.00$.

\section{EARLY RED BERMUDA.}

Large red potato, good yielder. Per bushel, \$1.75. SOUTHERN QUEEN.

Medium early, large white potato. Per bushel, $\$ 1.50$. DOOLY YAM.

This is the old time yellow yam, a well known variety. Skin rich yellow color, flesh deep yellow, cooks soft and very sweet, excellent flavor, round leaf. sometimes called pumpkin yam by some. Price, per bushel, $\$ 1.75$.

\section{SPECIAI.}

We have contracted for a car of genuine (New Jersey State) Jersey Chunks. This is the famous Yellow Jersey Potato that is in such demand through the Eastern and Western market. They come in bushel hamper and 3-bushel barrel. You should have some of this stock. Prices are reasonable.

Genuine Yellow Jersey, per hamper..........\$1.75 Genuine Yellow Jersey, per 3 -bu. barrei.........\$\$5.50 special prices on quantities.
We make a specialty of these potatoes, and we have now a good supply of Yellow Jersey and Yellow Nansemond, also Red Bermuda and Southern Queen. On the odd varieties, such as Black Spanish, Early Golden, Pride of Kansas, White Brazilian, Vineless, Red Jersey, Red Nansemond and Southern Yams, our supply is limited and you should get your orders in early so that we may know what you will want, and we will book same and ship as soon as it is time to put them out.

Buyers will please note that owing to the tenderness of Sweet Potatoes we do not guarantee the safe arrival of Sweet Potato Plants or seeds; however, we use all precautions necessary in packing and time of shipping.

\section{Common Varieties.}

FANCY YELLOW, JERSEY, KAW VALLEY. Per bushel crate, $\$ 1.25$.

FANCY YELLOW, NANSEMOND, KAW VALLEY. Per bushel crate, $\$ 1.25$.

RED NANSEMOND, KAW VALLEY.

Per bushel crate, $\$ 1.75$.

\section{RED JERSEY, KAW VALLEY.}

Per bushel crate, $\$ 1.75$.

\section{Varieties.}

\section{SOUTHERN YAM.}

We have the genuine. This potato is yellow in color and when cut, the meat is salmon color and very fine, a heavy yielder. Per bushel, $\$ 2.00$.

\section{BLACK SPANISH.}

Long, dark purple potato, white meated, good keeper, matures late. Per bushel, \$2.00.

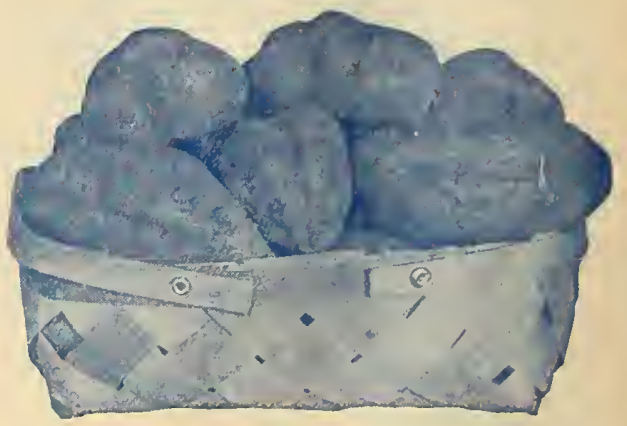

YELLOW NANSMOND.

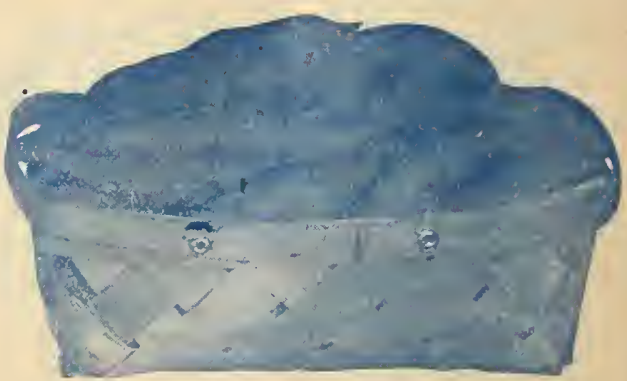

EARIY RED BERMUDA. 


\section{SWEET POTATOES}

TWO NEW VARIETIES THAT ARE NOW COMMANDING ATTENTION.

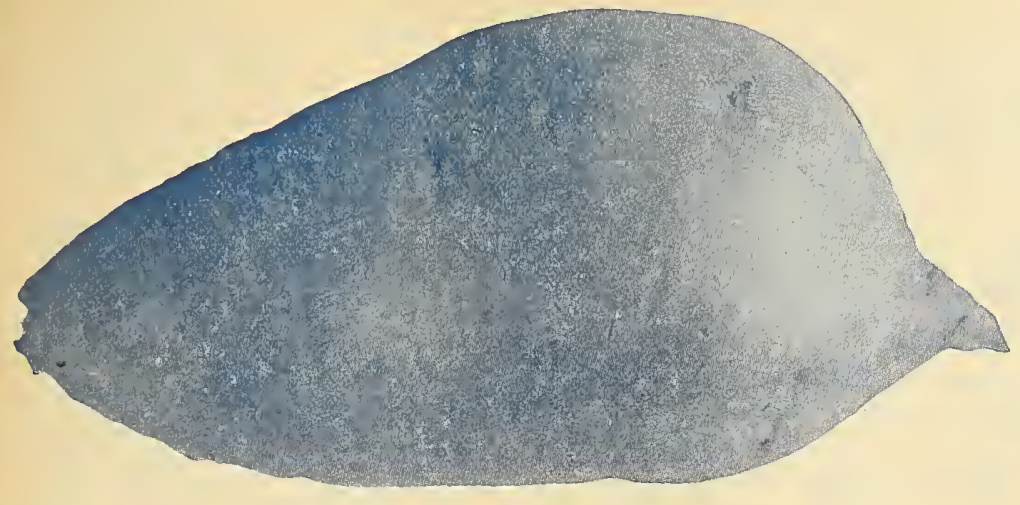

\section{The Nancy Hall}

This Potato was first introduced by us to our Northern Growers two years ago, and is now rapidly taking the lead over all other varieties. The Potato in color is a very pale pink (flesh color). The meat is a rich. sweet, golden yellow when cooked, and is one of the best keepers now grown. Price per bu., $\$ 2.00$.

\section{Porto Rica}

This Potato was brought to this country from SOUTH AMERICA two years ago, and planted in FLORIDA, where they call it the KEY WEST. We will introduce this GRAND NEW SWEET POTATO for the FIRST TIME to our Northern planters this coming season. The color of this Potato is PINK, with a rich golden yellow meat, free from strings, and very sweet; syrup fairly runs out of this Potato while baking. Price, per bu., $\$ 2.50$.

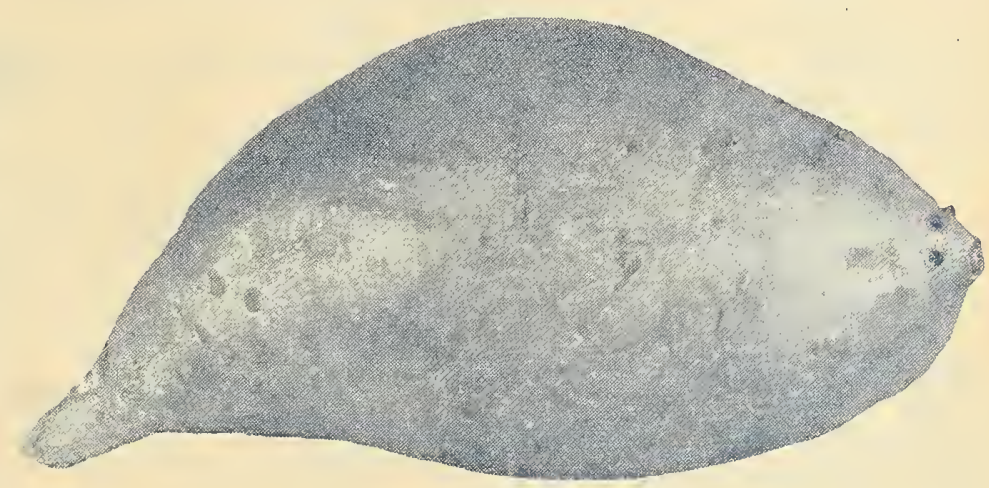

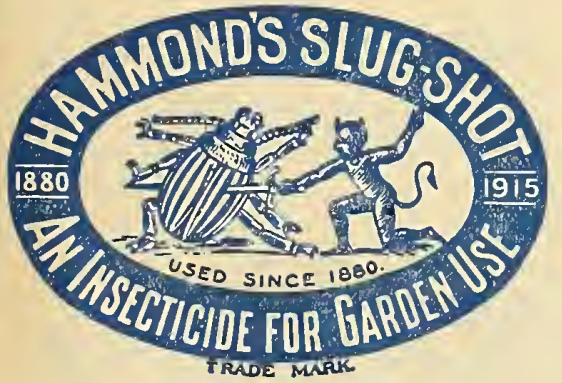

SLUG SHOT.

It is cheap and very effective. Destroys potato bugs, beetles, green and black fly, melon, squash and cucumber bugs, etc. $1 \mathrm{lb}$. carton, $15 \mathrm{c} ; 1 \mathrm{lb}$. canister with shaker top, 25c; 5 lb pkg., 50c. Postage extra.
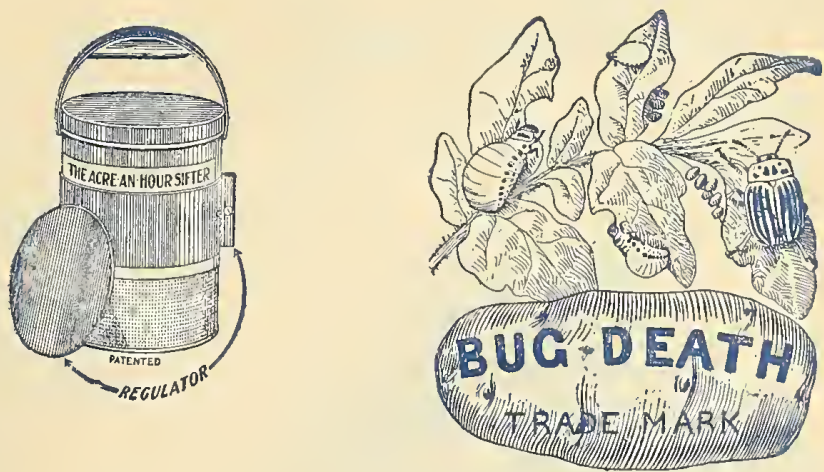

BUG DEATH.

Kills all bugs and worms that chew the leaves and foliage. Contains no Paris green nor arsenic. May be used dry or in solution with any sprayer on th market. Lb., $15 \mathrm{c}$; 3 lbs., $35 \mathrm{c}$; 5 lbs., $50 \mathrm{c}$; $121 / 21 \mathrm{bs}$., $\$ 1.00$. Dicky Duster, 25c; an Acre-an-Hour Sifter. $75 \mathrm{c}$, are especially adapted to applying Bug Death.

\section{Send 20c for $1 \mathrm{lb}$ of our New Large Ear SWEET CORN. Back Page.}




\section{PLANTS}

NOTE-All our plants will be packed in sea moss this season, which will insure more safe delivery and less express charges.

Plants herein quoted are shipped from our own beds at Topeka, Kansas. We pay postage on lots of 100. Add $10 \mathrm{c}$ per 100 plants for additional lots by parcel post. Express is the best way on large lots, however, we will ship them any way you desire that they will come through safely and at the least expense.

\section{SWEET POTATO}

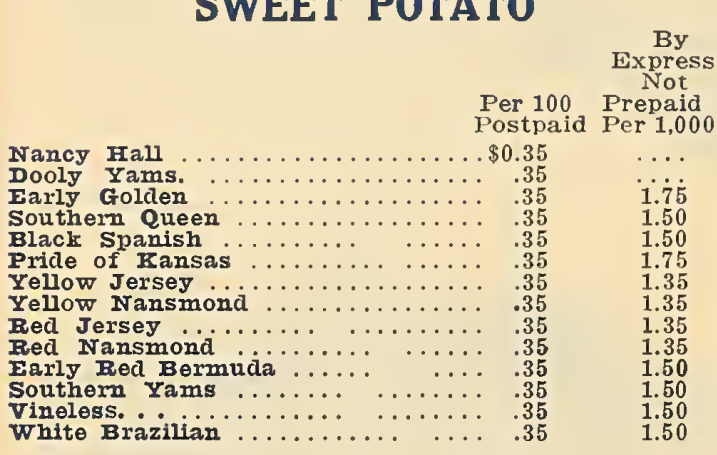

\section{CABBAGE PLANTS}

If in the market for frost-proof cabbage plants, write us for delivered prices.

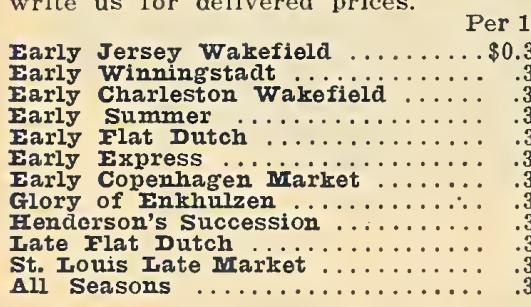

Per 100 Per 1,000

\section{PEPPER PLANTS}

Ruby King

Iong Red

Perfection Gian

$\$ 1.75$

1.75

1.75

1.75

1.75

2.00

2.00

1.75

1.75

1.75
1.75

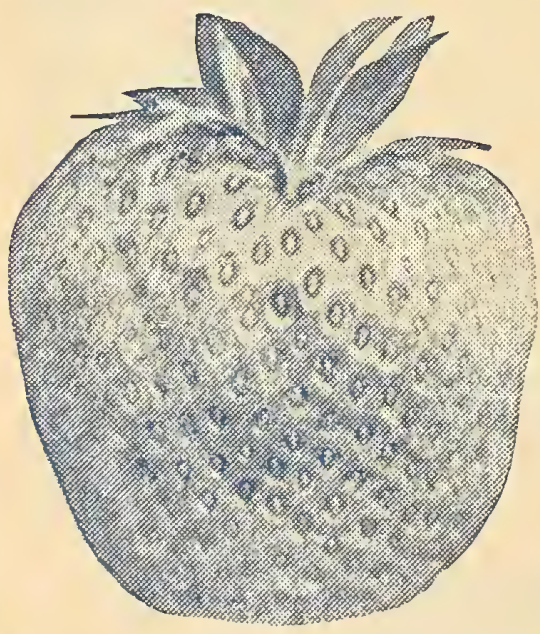

EGG PLANTS

Early New York $\ldots \ldots \ldots \ldots \ldots \$ 0.50$

$\$ 4.00$

Black Beauty

4.00

\section{TOMATO PLANTS}

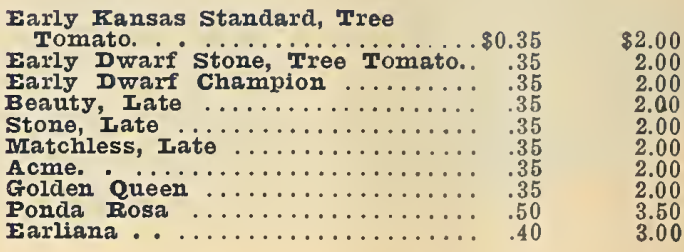

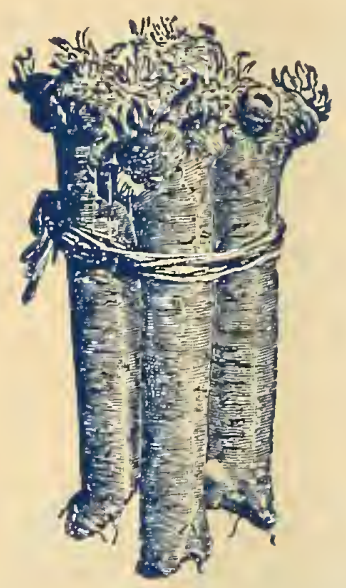

HORSE-RADISH ROOTS.

We have several thousand slips to offer this season. Fine stock, 6 to 10 inches long. Per 1,000 , $\$ 3.00$; per $100,40 \mathrm{c}$; per $10 \mathrm{v}$. by mail or express, prepaid, $75 \mathrm{c}$.

\section{Raspberries}

St. Regis, Large Red, per $1,000, \$ 10.00$.

Cumberland Black Cap, per 1,000, $\$ 10.00$.

\section{Strawberries}

We have some very fine plants in the following varieties:

IARGE TYPE PROGRESSTVE EVERBEARING.

Blooming and bearing till killed by frost. We have the genuine; price per $100, \$ 1.50$; per $500, \$ 5.50$; per 1,000 , $\$ 11.00$.

SEN. DUNIAP, GANDY, AROMA, KIONDIKE, WAREIEID, CRESCENT, MICHARIS, EARIY BRANDWINE.

Price, per $100,65 \mathrm{c}$; per $500, \$ 3.00$; per $1,000, \$ 6.00$. Postpaid and all charges paid by us. 


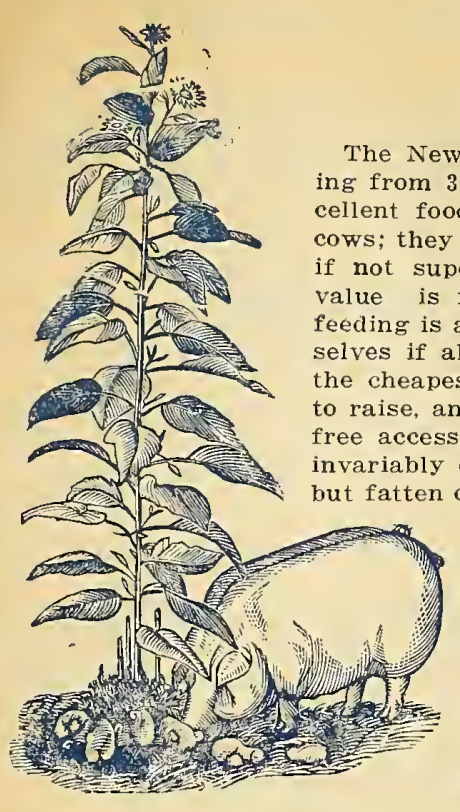

\section{ARTICHOKES}

The New Large Jerusalem Variety, producfrom 300 to 600 bushels per acre. An exfood for hogs, cattle, sheep and milch are for the production of milk equal arior to bran. But their greatest is avoided, as the hogs will help themif allowed to do so. We consider them heapt and healthiest hog food possible raise, and find that where brood sows have ree access to Artichokes they and their pigs invariably do well. Hogs will not only grow, but fatten on them.

Price, $1 / 4$ bushel, $60 \mathrm{c}$ Price, per bushel, 50 pounds, $\$ 2.00$

Two bushels plant an acre.

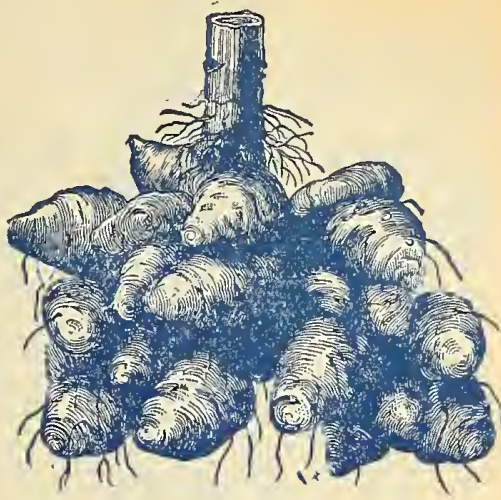

ARTICHOKE JERUSALEM.

\section{ARTICHOKE-IARGE GREEN GLOBE.}

\section{The Standard Variety}

The Globe Artichoke is cultivated for its flower-heads, which are cooked like asparagus. Plants set in any sood soil, with slight covering in winter,

\section{ASPARAGUS}

\section{PALMETTO.}

The earliest, finest and best variety. Strong and vigorous in growth; very rich and tender when cooked. Pkt., 5c; oz., 10c; 1/4 lb., 35c; 1 lb., 65c; postpaid.

\section{CONOVER'S COLOSSAL.}

An extra large quick growing variety; stalk measures over one inch in diameter. Pkt., 5c; oz., 10c; 1/4 lb., 20c; 1 lb., 60c; postpaid.

\section{ASPARAGUS ROOTS.}

Strong roots of the above varieties, $25 \mathrm{c}$ per dozen; $\$ 1.25$ per 100 by mail, postpaid. By express, 1 year old, 250 for $\$ 1.40 ; 500$ for $\$ 2.50 ; 1,000$ for $\$ 4.00 ; 2$ years old, 250 for
$\$ 1.60 ; 500$ for $\$ 2.50 ; 1,000$ for $\$ 4.50$.

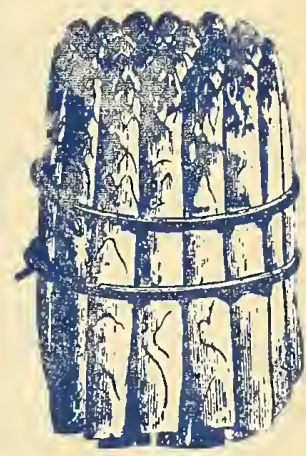

\section{RHUBARB}
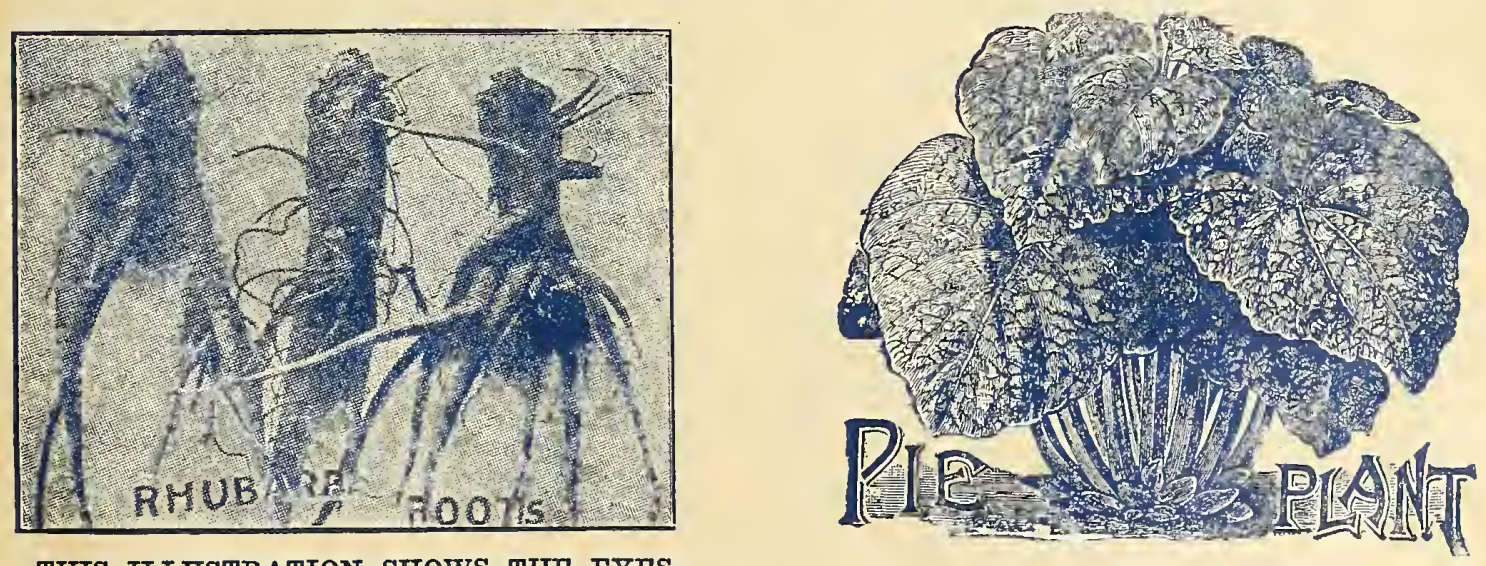

THIS ILLUSTRATION SHOWS THE EYES.

We have a selected lot of large Mammoth Victoria, also Wine Plant. Price, per dozen eyes, postpaid, 50c; per 100 eyes, $\$ 2.50$; per 1,000 eyes, by freight in bbls, $\$ 8.50$. 


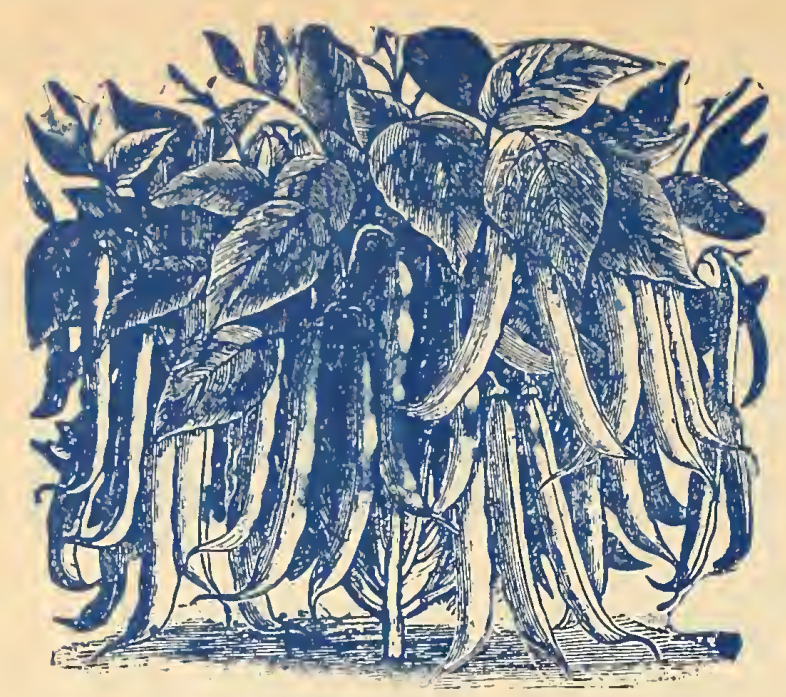

GIANT STRINGLESS GREEN POD

\section{Green Pod Varieties}

\section{BURPEES STRINGLESS GREEN POD.}

The best green podded bean on the market. It is very early, extremely vigorous and produces an abundance of brittle, stringless pods. Pkt., 5c; $1 / 2$ 1b., $15 \mathrm{c}$; 1 lb., $30 \mathrm{c}$, postpaid.

\section{GIANT STRINGLESS GREEN POD.}

The round, meaty pods resemble the early Red Valentine, but this bean matures a week or ten days later. The pods are quite stringless and brittle at all stages and this variety is to be recommended highly. Pkt., 5c; $1 / 2$ 1b., $15 \mathrm{c} ; 1$ lb., 30c, postpaid.

\section{BLACK VALENTINE.}

Long, stright, round, green pods of fair quality while young; enormously productive. Ready in 50 days from sowing for market. Pkt., $5 \mathrm{c} ; 1 / 2 \mathrm{lb}$., $15 \mathrm{c}$; 1 lb., $30 \mathrm{c}$, postpaid.

IMPROVED EXTRA EARLY RED VALENTINE.

An old favorite and has only recently been surpassed by the Stringless Green Pod. Very prolific and the pods are fine and round, and very tender while young. It is as early as the preceding one, but the pods are not quite as long nor as straight. Pkt., 5c; $1 / 2$ lb., $15 \mathrm{c}$; 1 lb., 30c, postpaid.

\section{EARLY YELLOW SIX WEEKS.}

The pods are long and flat and of a bright green color. Plants form erect bushes. Pkt., 5c; $1 / 2 \mathrm{lb}$., $15 \mathrm{c} ; 1$ lb., $30 \mathrm{c}$, postpaid.

\section{EXTRA EARLY REFUGEE OR BROWN SPECKLED VALENTINE.}

This may be called one of the second early sorts. Pods are round, of good flavor, but because of the great vigor of the bush it needs twice the usual room. Pkt., 5c; $1 / 2$ lb., $15 \mathrm{c} ; 1$ lb., $30 \mathrm{c}$, postpaid.

\section{LONGFELLOW.}

A new extra early variety with semi-round, uniformly straight pods; very fleshy, long, brittle and without strings when broken; flavor delicious; very prolific; plants very strong and compact in
growth. Plkt., 5c; $1 / 2$ lb., $15 \mathrm{c} ; 1$ lb., $30 \mathrm{c}$, jostpaid.

\section{ROUND YELLOW SIX WEEKS.}

A pale green bean of excellent flavor. Round pod. Very prolific. Pkt., 5c; $1 / 2$ lb., $15 \mathrm{c}$; 1 ib., $30 \mathrm{c}$, postpaid.

\section{BEANS}

NOTICE-Seed Beans, never was no scarce as they are at this time, and prices are very $\mathrm{high}$. We will flll all orders as long as our supply lasts, and we urge our customers to order at once. We sell all our seeds by weight. A pound of beans is a little more than a pint.

\section{Special}

\section{HAYES IMPROVED NEW WHITE NAVY.}

A very fine bunch bean, and one that can be used as a snap bean, or left to ripen and used as a soup bean. Give this bean a trial. No better bean grown. Pkt., 5c; $1 / 2$ lb., 20c; 1b., 30c, postpaid.

\section{IMPROVED GOLDEN WAX (Rust Proof.)}

The standard wax beans for years. The pods are large, slightly flattened, brittle, quite stringless when young, and of golden wax color. I tis very tc.nder, of fine flavor, and is unexcelled as a shell bean for winder use. The bushes are of compact growth and very prolific. Pkt., $5 \mathrm{c} ; 1 / 2$ lb., $20 \mathrm{c} ; 1$ lb., $35 \mathrm{c}$, postpaid.

\section{DWARF GERMAN BLACK WAX.}

Sometimes called Butter Beans. One of the earliest varieties, producing fine, round meat pods of good quality. Pkt., 5c; $1 / 2$ lb., 20c; 1 lb. $35 \mathrm{c}$, postpaid.

WARDWELL'S KIDNEY WAX.

Highly recommended for private planters and market gardeners. The pods are flat, straight, and are produced in large quantities. Pkt., 5c; $1 / 2$ 1b., $25 \mathrm{c} ; 1$ lb., $35 \mathrm{c}$, postpaid.

\section{PENCII POD BLACK WAX.}

Plant grows about 15 inches high, very productive, with straight pods 6 to 7 inches long, light golden yellow color, round, meaty and deeply saddlebacked; flesh brittle, solid and stringless; flavor fine. Pkt., 5c; $1 / 2$ lb., $20 \mathrm{c}$; $1 \mathrm{~b} ., 35 \mathrm{c}$.

CURRIE'S RUST PROOF BLACK WAX.

As near rust proof as a good bean can be. Very vigorous and hardy and productive. Pkt., $5 \mathrm{c} ; 1 / 2$ lb., 20c; 1 lb., $35 \mathrm{c}$, postpaid.

\section{DAVIS' WHITE WAX.}

This bean does not discolor, and is therefore excellent for canning. It is immensely productive and a very good shipper. The pods are straight and 5 to 6 inches in length. The dry bean is white and very desirable for winter use. Pkt., $5 \mathrm{c}$; $1 / 2$ lb.,20c; $1 \mathrm{lb} ., 35 \mathrm{c}$, postpaid.

\section{POLE OR RUNNING VARIETIES}

KENTUCEY WONDER OR OLD HOMESTEAD.

This has been for a long time the most popular bean. It is very vigorous, climbs well, and bears abundance of nearly round pods which are of ten ten inches long. Pkt., 5c; $1 / 2$ lb., $15 \mathrm{c} ; 1$ lb., $25 \mathrm{c}$.

KENTUCKY WONDER YELLOW PODDED.

Same general appearance as the Green Poded Variety. Very productive. Pkt., 5c; 1/2 1b., 15c; 1 lb., $30 \mathrm{c}$.

\section{IAZY WIFE.}

So named because of the easy picking, and a very popular bean in some localities. Pods are broad, thick, very fleshly, entirely stringless and of a rich buttery flavor when cooked. The beans are white and make a good dry bean for winter use. Pkt., 5c; and make a good dry bear.

\section{CUT SHORT OR CORN HILL.}

The old standard for planting among corn. Pods are short, round and tender. Pkt., 5c; $1 / 21 \mathrm{~b} ., 15 \mathrm{c}$; 1 lb., $25 \mathrm{c}$. 


\section{Beans--.Continued}

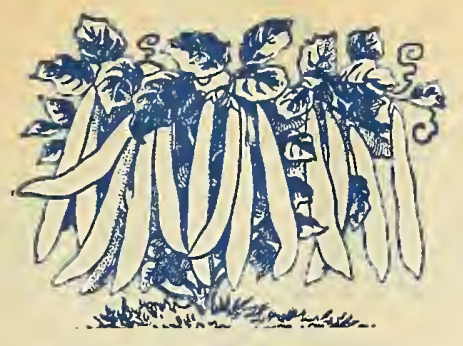

\section{BUSH LIMA BEANS}

BURPEES'S BUSH LIMA.

This is the bush form of the Large White Lima. The bush is about 20 inches high and up to two and a half feet in diameter, bearing from 50 to 100 large pods Plst, $5 \mathrm{c}, 1 / 2 \mathrm{lb}, 15 \mathrm{c} ; 1 \mathrm{~b}, 25 \mathrm{c}$, postpaid

\section{HENDERSON'S BUSH LIMA.}

This bean is about two weeks etarlier than the pole Limas. It needs no stakes and produces an enormous crop of delicious Lima Beans, Pkt. 5c; $1 / 2$ lb., $15 \mathrm{c}, 1$ lb, $25 \mathrm{c}$, postpaid.

\section{POLE LIMA BEANS}

KING OF THE GARDEN LIMA.

This is a decided improvement over the large White, being a strong grower, very productive and bearing large, well filled pods. The beans are usually shelled, of fine quality and excellent flavor. Pkt, 5c, 1/2 1b, 20c, 2 lbs, $35 \mathrm{c}$.

\section{SMALI CAROLINA, OR SIEVA IIMA.}

This is a small type of the pole limas. It matures quickly, produces immense crops, and makes an excellent bean for winter use. Pkt, 5c, 1b, 20c; 2 lbs, 35c, postpaid

\section{TEPARY BEANS.}

From Arizona, drouth resisting. Per 1b., 25c, postpaid

\section{Table Beets}

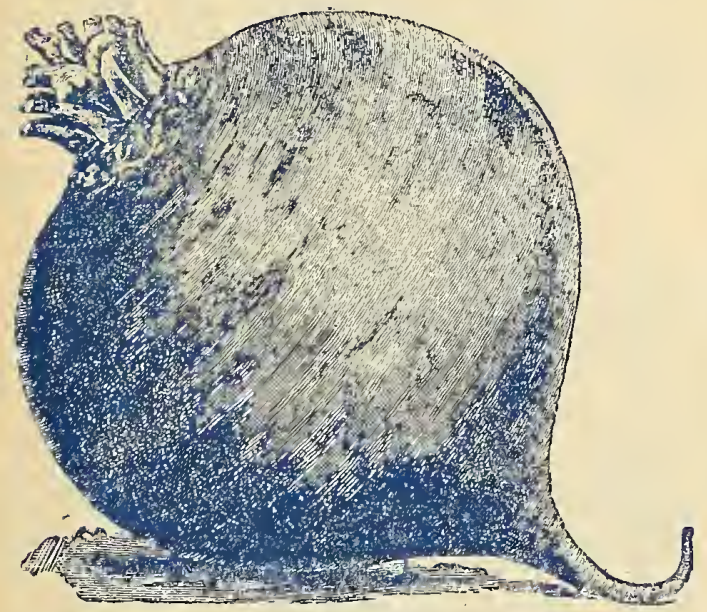

EARLY ECLIPSE.

\section{ECLIPSE.}

This is as early as the Egyptian, but is more desirable owing to its globe shape, smoothness and regularity. It has a small firm top, is very sweet, fine and of dark red color. Pkt., 5c; oz, 10c; $1 / 4$ fine and of dark red color.
$1 \mathrm{~b}, 25 \mathrm{c}, 1 \mathrm{~b}, 75 \mathrm{c}$, postpaid.

\section{Table Beets}

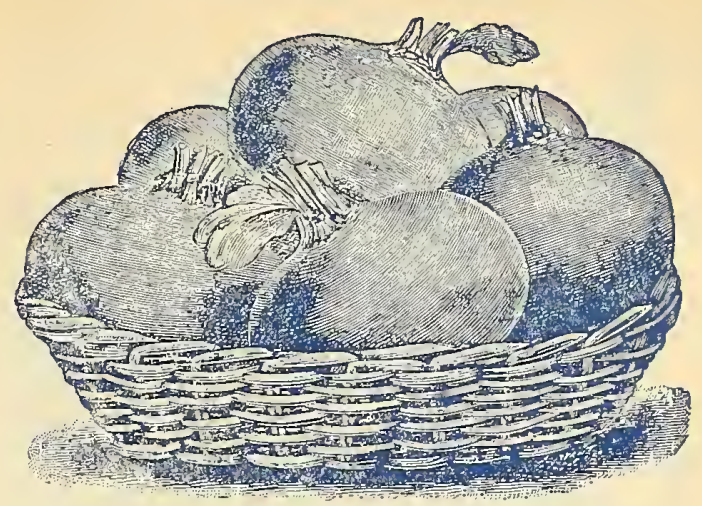

CROSBY'S EARIY EGYPTIAN.

One of the earliest and best on market. It is more globular than the Early Egyptian Especially good for market gardeners. Pkt, 5c; oz, 10c, $1 /$ lb. $25 \mathrm{c}$; 1b. $75 \mathrm{c}$, postpaid.

\section{EARLY BLOOD RED TURNIP.}

This is a turnip beet, and is the old standard among the early varieties. It is of dark red color and is perhaps the most popular of all beets. Pkt. $5 \mathrm{c}$; oz., $10 \mathrm{c}$; $1 / 4$ lb., $25 \mathrm{c}$; 1b., $75 \mathrm{c}$, postpaid.

\section{EXTRA EARLY EGYPTIAN.} An extra early turnip-shaped variety, has small rings of white and red. Pkt, $5 \mathrm{c}, \mathrm{oz}, 10 \mathrm{c}, 1 / 4 \mathrm{~b}$. rings of white and red.
$25 \mathrm{c}$; $1 \mathrm{~b}$., $75 \mathrm{c}$, postpaid.

\section{DETROIT DARK RED.}

A choice strain of dark red turnip beet of globular to oval shape with smooth roots and small tops. Slín is blood red, zoned with light shades, tender and sweet. Fine for market and canning, Pkt. $5 \mathrm{c} ; \mathrm{oz}, 10 \mathrm{c} ; 1 / 4 \mathrm{~b}, 25 \mathrm{c}, 1 \mathrm{~b}, 75 \mathrm{c}$, postpaid.

\section{THE LFNTZ.}

As early as the Egyptian, flesh very tender and sweet at all times. Very productive, a good keeper and will produce crop in six weeks from time of planting. Pkt, $5 \mathrm{c} ; 0 \mathrm{z}, 10 \mathrm{c} ; 1 / 4 \mathrm{db}, 25 \mathrm{c}, 1 \mathrm{~b} ., 75 \mathrm{c}$

\section{FDMOND'S BLOOD TURNIP.}

Handsome round shape, skin very deep, blood red color, flesh very dark and exceedingly sweet and tender, Very regular and of good size. Make excellent bunch beeets. Pkt, $5 \mathrm{c}, \mathrm{oz}, 10 \mathrm{c}, 1 / 4 \mathrm{~b}, 25 \mathrm{c}$; lb. $75 \mathrm{c}$, postpaid.

\section{HALF IONG RED.}

Larger than the turnip beets and makes a heavier yield Pkt., $5 \mathrm{c}$; oz, $10 \mathrm{c}$; $1 / 4 \mathrm{tb}, 25 \mathrm{c}$; $1 \mathrm{~b}, 75 \mathrm{c}$, postpaid

\section{LONG BLOOD RED.}

The old standard variety for table and cattle It is the best drouth resister of all; color deep red, flesh very sweet. Grows entirely under the ground Pkt, 5c; oz, $10 \mathrm{c}$, 1/4 1b, $25 \mathrm{c}, 1 \mathrm{~b}, 75 \mathrm{c}$, postpaid.

\section{SWISS CHARD OR FOLIAGE BEET.}

This is a distinct vegetable from the common beet, much superior for greens, and is ready for use much earlier. When mature, the plant forms broad, flat and beautifully white and wax-like stems. which are very delicious when cooked as beets and asparagus tips, or pickled. We recommend this asparagus tips, or pickled. We recommend this
beet. Pkt, $5 \mathrm{c} ;$ oz, $10 \mathrm{c} ; 1 / 4 \mathrm{~b}, 25 \mathrm{c}, 1 \mathrm{~b}, 75 \mathrm{c}$, postpaid. 


\section{SUGAR BEETS AND STOCK BEETS}

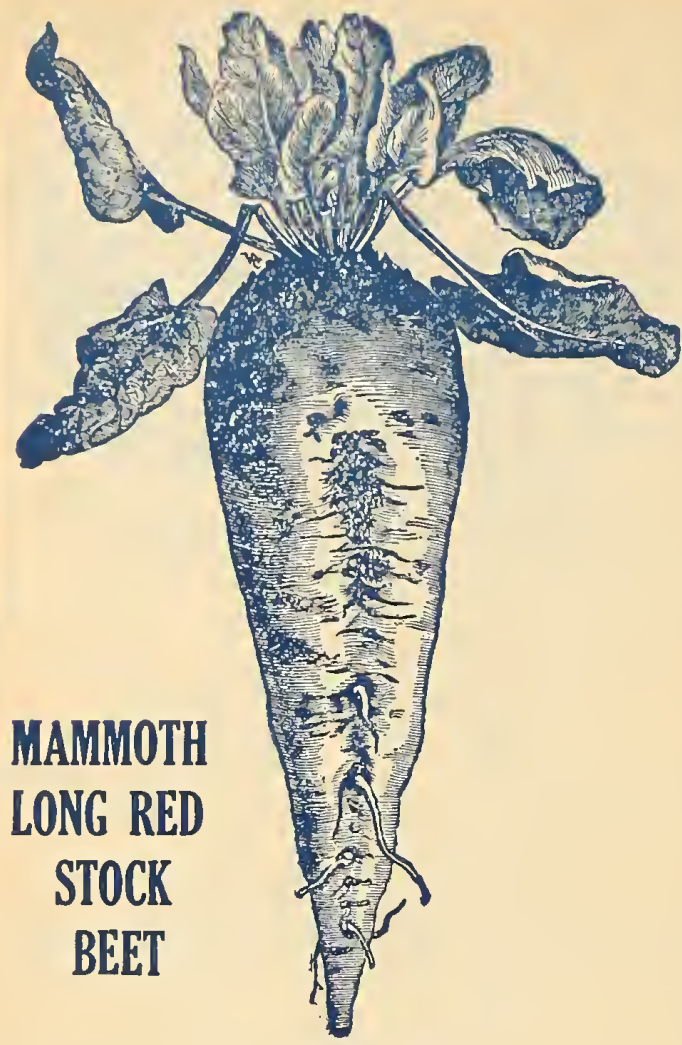

\section{Sugar Beets}

\section{RED TOP SUGAR.}

Fine, sweet flesh and the best for cattle feedIng. Óz., 5c; 1/4 1b., 15c; 1b., 40c, postpe.id.

\section{LANE'S IMPERIAL SUGAR.}

Will yield almost as much as the best Mangel. Oz., 5c; $1 / 4$ lb., $15 \mathrm{c}$; 1b., 40c, postpaid.

\section{Stock Beets}

YELLOW GLOBE MANGEL.

This beet is easily pulled and more delicate than the Long Red. Oz., 5c; 1/4., 1b., 15c; 1b., $40 \mathrm{c}$.

\section{GOLDEN TANKARD.}

This is a yellow beet, the most prolific variety, and very nutritious. It is one of the most profitable var
lb., $40 \mathrm{c}$.

\section{MAMMOTH LONG RED MANGEL.}

These roots attain an enormous size and it is a fine variety for feeding. Oz., $5 \mathrm{c}$; $1 / 4 \mathrm{~b} ., 15 \mathrm{c} ; 1 \mathrm{~b}$. ., $40 \mathrm{c}$.

\section{RED GLOBE MANGEL.}

This variety is especially adapted to shallow soils. It is a large, round beet, red-skinned and white fleshed. It is an excellent keeper. Oz., $5 \mathrm{c} ; 1 / 41 \mathrm{~b}$., $15 \mathrm{c}$; 1b., $40 \mathrm{c}$.

\section{BERCOLE OR KALE.} $50 \mathrm{c}$.

Dwarf German Purple. Oz., 10c; 1/4 1b., 15c; 1b.,

\section{BRUSSELS SPROUTS.}

Oz., 15c; 1/4 1b., 50c; 1b., $\$ 2.00$.

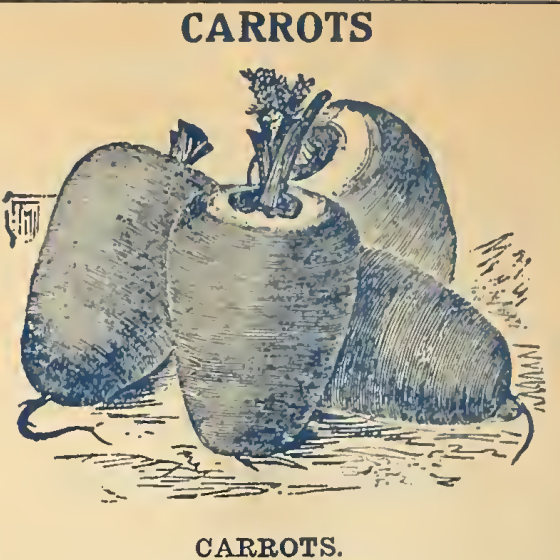

Table Use

EXTRA EARLY SHORT FORCING.

An excellent forcing variety; very tender, small tops, and of fine flavor. I'kt., $5 \mathrm{c}$; 0 z., $10 \mathrm{c}$; $1 / 4 \mathrm{lb}$., $25 \mathrm{c} ; 1 \mathrm{~b} ., 85 \mathrm{c}$.

\section{EARIY SCARLET HORN}

A very early variety. Recommended for the market and home garden. Texture very fine and very delicate in flavor. Pkt., 5c; oz., $10 \mathrm{c}$; $1 / 4$ Ib., 25c; 1b., $85 \mathrm{c}$.

\section{OXHEART OR GUERANDE.}

The French Carrot is one of the most valuable varieties either for family use or for the market. It is an intermediate between the half long and the Horn types attaining a diameter of 3 to 4 inches at the neck. It is very productive, rich orange color and beautiful shape. Pkt., 5c; oz., $10 \mathrm{c}$; $1 / 4$ 1b., 25c; lb., 85c.

\section{CHANTENAY OR MODEL.}

A nice smooth carrot of perfect and uniform shape. A heavy yielder a fine table quality, 5 to 6 inches long and easily dug. The flesh is of a deep yellow color tender and of excellent flavor. Pkt. $5 \mathrm{c}$; Oz., 10c; $1 / 4$ lb., $25 \mathrm{c}$; 1b., $85 \mathrm{c}$ DANVERS HALF LONG.

Admirable in color, fixed in habit, a wonderful producer, the best of all for the stock breeder, and valuable to the market gardener. With this variety the planters secure the largest return to the acre, with the least difficulty of harvesting. Pkt. 5c; oz., 10c; 1/4 1b., 25c: 1b. $85 \mathrm{c}$

\section{HALF LONG SCARLET NANTES.}

Foliage finely cut, dark and of medium height roots slender, smootl, and of a bright orange color, flesh orange becoming yellow towards the center. but with no distinct core. Quality very fine. Pkt., $5 \mathrm{c}$; oz., $10 \mathrm{c}$; $1 / 4 \mathrm{lb} ., 25 \mathrm{c}$; 1b., $85 \mathrm{c}$.

\section{Stock Feeding} IMIPROVED LONG ORANGE.

Pkt., 5c; 0z., 10c; 1/4 1b., 20c; 1b., 60c. LARGE WHITE BELGIAN.

Pkt., 5c; oz., 10c; 1/4 1b., 20c; 1b., 60c. IARGE YELLOW BELGIAN.

Pkt., 5c; oz., 10c; 1/4 1b., 20c; 1b., 60c.

\section{CAULIFLOWER}

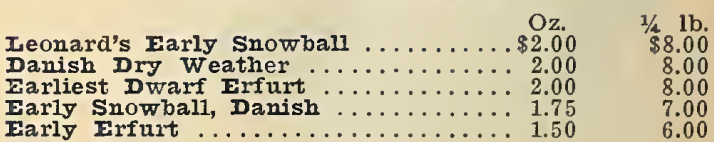

\section{CELERY}

GOLDEN SELF BLANCHING.

Pkt., 5c; oz., $30 \mathrm{c}$; $1 / 4 \mathrm{lb}$., $\$ 1.00 ;$ lb., $\$ 4.00$. GIANT PASCOT.

Pkt., 5c; oz., 15c; 1/4 lb., 50c; lb., $\$ 2.00$. CETERIAC.

Large Turnip Rooted. Oz., 10c; 1/4 1b., 40c; 1 lb., $50 \mathrm{c}$.

\section{CHICORY}

LARGE ROOTED OR COFFEE.

Pkt., 5c; oz., 10c; 1/4 lb., 30c; 1b., $\$ 1.00$ 


\section{CRESS}

FOR SALADS.

Pkt., 5c; oz., 10c; 1/1/1 1b., 20c;

CORN SALAD.

Large leaved. Oz., $5 \mathrm{c} ; 1 / 4 \mathrm{lb}$

\section{COLLARDS}

GEORGIA SOUTHERN OR CREOLE.

\section{CUCUMBERS}

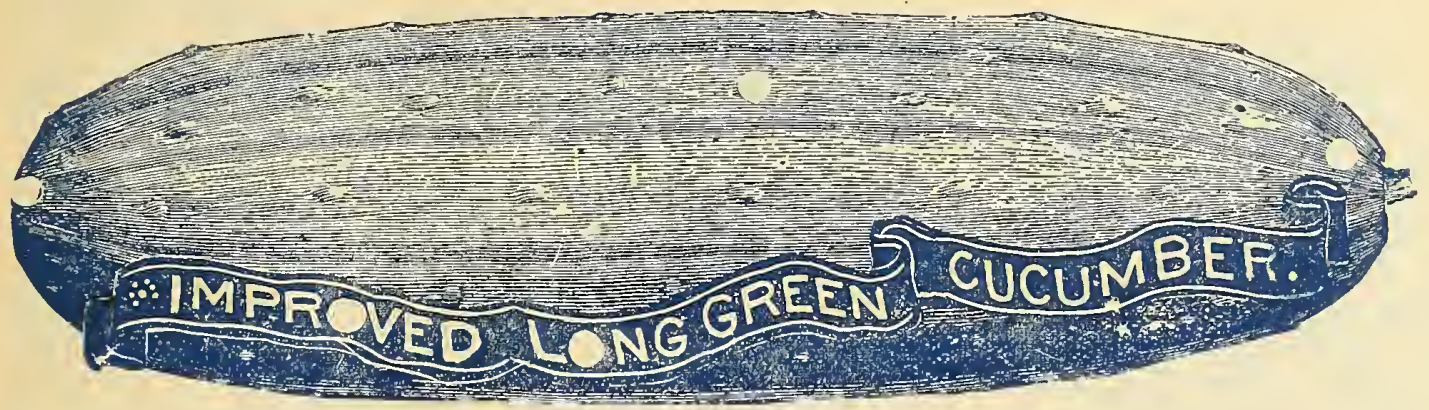

The most popular variety grown. Cucumbers grow from 8 to 12 inches in lengtli. Pkt., 5c; oz., 10c;

COOL AND CRISP.

This new Cucumber is said to be the earliest of all pickling varieties, and is one of the finest for slicing. Pkt., $5 \mathrm{c}$ : oz., $10 \mathrm{c}$ : $1 / 4$ lb., $25 \mathrm{c} ; 1 \mathrm{lb}, 75 \mathrm{c}$.

DAVIIS PERFËCT.

The new dark green market strain of Long White Spine. Pkt., 5c; oz., 10c; 1/4 lb., 25c; 1 lb., $75 \mathrm{c}$ EARLY' CLUSTER.

Fruit small and borne in pairs; light green, a great bearer. Pkt., 5c; oz., 10c; 1/4 lb., 25c; 1 lb.,

\section{EARLY GRAME OR SHORT GREEN.}

A vigorous grower and great producer: medium size, very early and good for pickling or slicing. Pkt., 5c; oz., 10c; $1 / 4$ 1b., $25 \mathrm{c}$; 1 lb.; $75 \mathrm{c}$
FORDHOOK FAMOUS.

One of the best of the long green type. Pkt., 5c; oz., $10 \mathrm{c} ; 1 / 4$ lb., 25c; 1 lb., $75 \mathrm{c}$.

Fruit about 10 inches long, thick and fine flavor. Skin dark green, flesh pure white; can be grown on trellises and fences. Pkt., 5c; oz., $10 \mathrm{c} ; 1 / 41 \mathrm{~b} ., 25 \mathrm{c}$; $1 \mathrm{lb} ., 75 \mathrm{c}$.

\section{KLONDIKE.}

A splendid strain of White spine with dark green skin. Pkt., $5 \mathrm{c}$; oz., $10 \mathrm{c}$; $1 / 4$ 1b., $25 \mathrm{c} ; 1 \mathrm{lb} .75 \mathrm{c}$

\section{IIVINGSTON'S EV̈ERGREEN.}

Early and prolific; remains deep green in all

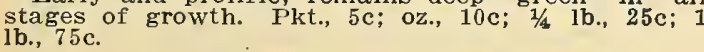

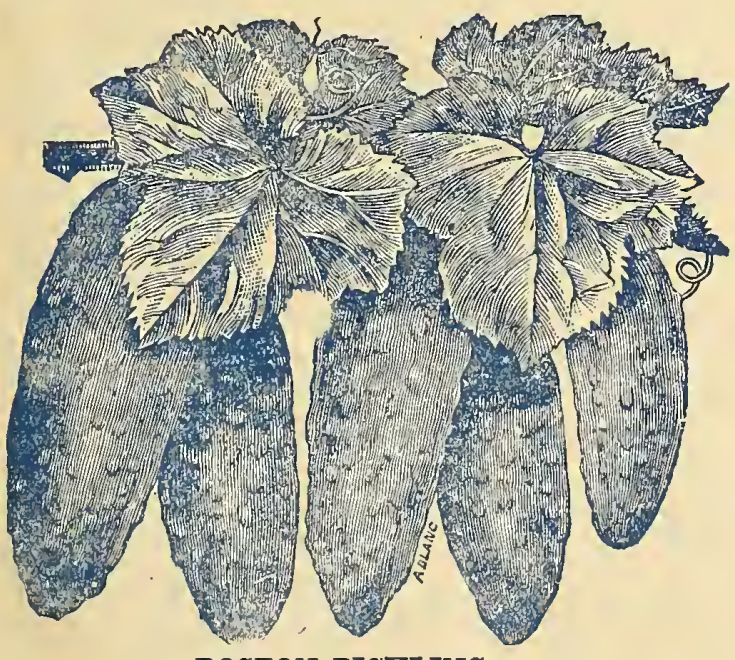

BOSTON PICKIING.

Fruit short, smooth and pointed at each end: bright green, and a great yielder; one of the best for pickling. Pkt., $5 \mathrm{c}$; oz., $10 \mathrm{c}$; $1 / 4 \mathrm{~b}$., $25 \mathrm{c} ; 1 \mathrm{lb}$.. $75 \mathrm{c}$.
THORBURN'S EVERBEARING.

Sets fruit very early and continues to blossom and fruit until killed by frost; good pickler or slicer. Pkt., 5c; 0z., 10c; 1/4 1b., 25c; 1 lb., $75 \mathrm{c}$

\section{WESTERFIELD'S CHICAGO PICKLE.}

The favorite with Chicago pickle maufacturers; fine shape and very productive. Pkt., $5 \mathrm{c}$; oz., $10 \mathrm{c}$ $1 / 41 \mathrm{~b} ., 25 \mathrm{c} ; 1$ lb., $75 \mathrm{c}$.

\section{WEST INDIA GHERKIN.}

This is the only genuine Gherkin. It is small, oval and covered with spines; color light green. Pkt. $5 \mathrm{c}$; oz., $10 \mathrm{c}$; $1 / 4 \mathrm{lb}$., $25 \mathrm{c}$; $1 \mathrm{lb}$., $75 \mathrm{c}$.

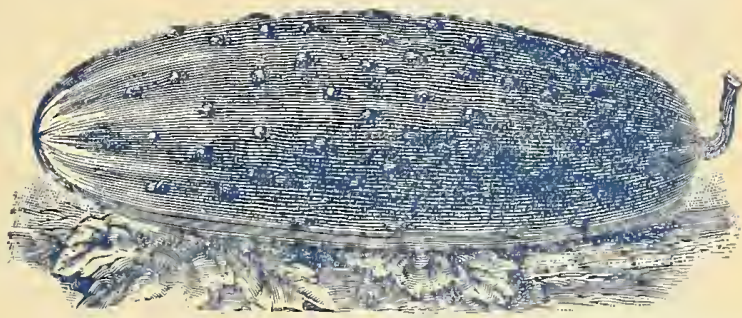

WHITE SPINE, EVERGREEN OR EXTRA LONG

An extra long type of White Spine; fruit handsome and an abundant bearer. Pkt., $5 \mathrm{c}$; oz., $10 \mathrm{c}$

WHITE SPINE, IMPROVED EARLY.

The most popular strain of White Spine, and for general outdoor culture the best. Pkt., $5 \mathrm{c}$; oz., $10 \mathrm{c}$

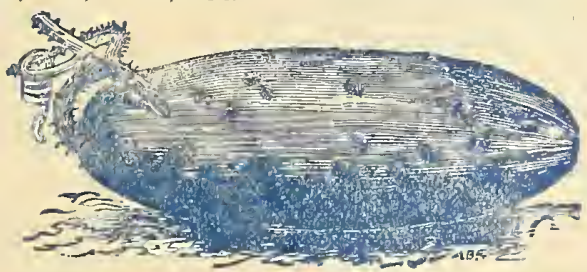

WHITE SPINE, ARLINGTON IMPROVED.

One of the finest for forcing and one of the most perfect in shape, size, color and quality. Pkt., 5c; oz., $10 \mathrm{c}$; $1 / 4 \mathrm{lb}$., $25 \mathrm{c}$; 1 lb., $90 \mathrm{c}$.

Our Cucumber Seed is the Best you can buy, grown in Michigan without irrigation. 


\section{Sweet Corn of Superiority}

\section{Quality Tested and True to Name. Our Sweet Corn is Grown in Kansas and Central Illinois. We Are Offering Exceptionally Fancy Seed This Season. Send in Your Order at Once.}

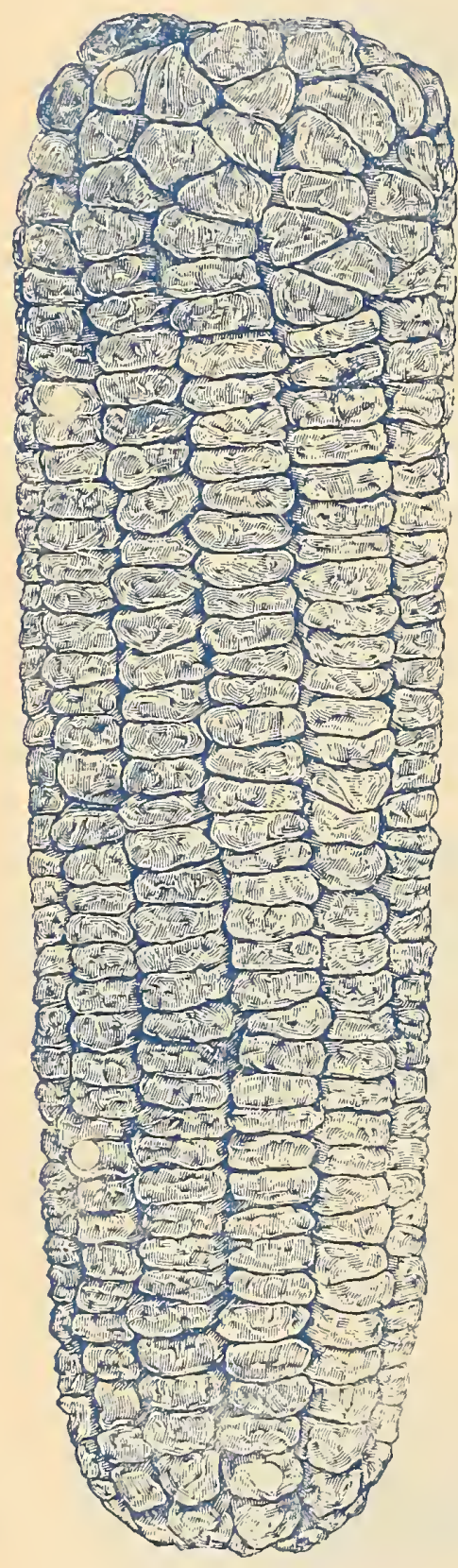

\section{EXTRA EARLY EVERGREEN.}

This undoubtedly is the swcetest and most dclicious corn it is possible to secure. market trade. Ears large and filled with the sweetest and most de-
licious corn you have cver tasted. Pkt., 5c; lb., 25c, postpaid.

\section{EARLY MAMMOTH.} $20 \mathrm{c}$

The largest eared early sweet corn ever produced. Pkt., 5c; lb.,

\section{PEEP-O'DAY.}

The earliest of all. This is a variety that is of the greatest value to all who desire the Very Earliest variety and one that can be depended upon to yield a profitable crop. Pkt., 5c; lb., $25 \mathrm{c}$.

\section{EARLY CORY.}

A popular extra early variety. Pkt., $5 \mathrm{c}$; lb., $25 \mathrm{c}$. GOLDEN BANTAM.

It is an attractive yelliw color; very early and exceedingly sweet. Pkt., 5c; 1b., $25 \mathrm{c}$.

\section{EARLY ADAMS.}

Exceedingly early, but is not a swet corn. Pkt., 5c; 1b., 20c.; 2 lbs., $35 \mathrm{c}$.

\section{PERRY'S HYBRID.}

This is a gardener's favorite. Pkt., 5c; 1b., $25 \mathrm{c}$. EARLY MTNNESOTA.

One of the very earliest varieties. Pkt., $5 \mathrm{c} ; 1 \mathrm{~b} ., 25 \mathrm{c}$. CROSBY'S EARLY.

Another extra early variety. Pkt., $5 \mathrm{c} ; 1 \mathrm{~b} ., 25 \mathrm{c}$. COUNTRY GENTLEMAN.

Has been called Quaker Sweet, Shoe Peg, etc.; it is well known and needs no description. Pkt., $5 \mathrm{c} ; 1 \mathrm{~b}, 25 \mathrm{c}$ BURPEE'S FIRST OF AIL.

Pkt., 5c; lb., 25c.

\section{BURLINGTON HYBRID.}

Pkt., 5c; 1b., 20c; 2 lbs., $35 \mathrm{c}$.

Pkt., 5c; 1b., 25c. WHITE MEXICAN.

Pkt., $5 \mathrm{c} ; 1 \mathrm{~b} ., 25 \mathrm{c}$.

\section{BLACK MEXICAN.}

\section{ZIGZAG EVERGREEN.}

This fine new strain possesses the distinct characteristics which have made Stowell's Evergreen so deservedly the favorite for main crop, but produces ears fit to use from one week to ten days earlier. Plt., $5 \mathrm{c} ; \mathrm{lb}, 25 \mathrm{c}$.

\section{STOWELL'S EVERGREEN.}

This standard main crop variety excels all other late sorts in sweetness and productiveness. It is more popular than any other for canning, for marketing and for the home garden. Pkt., $5 \mathrm{c}$; 1b., $25 \mathrm{c}$. KENDALL'S EARLY GIANT.

A valuable early sweet corn. The ears grow to a tremendous size, measuring eight to ten inches long, and having ten to eighteen rows on each cob, the majority having twelve rows; kernels pure white; sweet, teender. Pkt., 5c; lb., 25c.

\section{CROSBY'S EARLY.}

An early corn of large size and choice quality. It has long been a standard variety. Pkt., 5c; $1 \mathrm{~b}$., $20 \mathrm{c}$

\section{EGYPTIAN OR WASHINGTON MARKET.}

A standard variety, in season between Evergreen and Mammoth Sugar. Very sweet and well adapted for canning. Pkt., 5c; 1b., $25 \mathrm{c}$.

\section{IATE MAMMOTH SUGAR.}

A large late variety having ears of mammoth size, 14 to 20 rows. Quality excellent, not exceeded by any variety. A good canners' variety, being white grained and very uniform. A week later than Stowell's Evergreen. Pkt., 5c; 1b., 25c.

IARGE PKT., 3 OZ., 5c; 1 1b., 25c; 2 lbs., 35c, POSTPAID BY US.

NOTE. On all seeds or merchandise where we quote the prices prepaid by us, if they are included in frelght shipments we wlll allow you to deduct the postage charge from each item. 


\section{CABBAGE SEED OF HIGHEST QUALITY}

Our seeds is both imported and Iong Island (N. Y.), grown, and especially grown for the market gardener and general home use.

\section{1-ST. IOUIS LATE MARKET CABBAGE.}

The seed $I$ offer comes direct from the original introducer of St. Louis and is the True St. Iouis varket seed. The plant is very vigorous and hardy the leaves are large and broad, the stem of moderate length, the head is large, white and solid, and seldom bursts. It is medium late in maturing, and is an excellent shipper. St. Louis shippers use this cabbage largely for shipping South. Pkt., 5c; oz., 15c; 1/4 lb., 50c; $1 / 2$ lb., $\$ 1.00$; lb., $\$ 2.00$, postpaid.

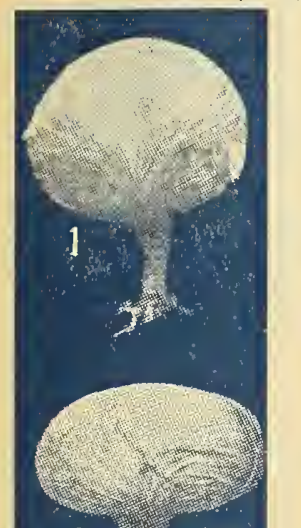

2

5

6

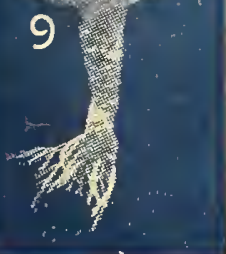

\section{2-SHORT-STEM DRUMEHEAD.}

Heads are of immense size, hard and solid, very uniform. Pkt., 5c; oz., 10c; $1 / 41 \mathrm{~b} ., 50 \mathrm{c}$; $1 \mathrm{~b}$., $\$ 1.50$, postpaid.

\section{EARIY WINNINGSTADT.}

Forms large cone-shaped heads of fine quality. Pkt., 5c; z., $15 \mathrm{c}$; $1 / 4$ lb., $40 \mathrm{c}$; $1 / 2$ lb., $75 \mathrm{c}$; lb., $\$ 1.25$, postpaid.

\section{EARLY JERSEY WAKEFIELD.}

An extra large variety, too well known to need any description. Pkt., 5c; oz., $15 \mathrm{c} ; 1 / 4$ lb., $40 \mathrm{c}$; lb., $\$ 1.50$, postpaid.

\section{EXTRA EARLY EXPRESS.}

One of the earliest on the market. Pkt., 5c; oz., $15 \mathrm{c} ; 1 / 4$ lb., $40 \mathrm{c}$; lb., $\$ 1.25$, postpaid.

\section{3-GIANT FLAT DUTCH.}

An extra large late winter variety, which has no superior and is one of the old standards. Pkt., 5c; oz., 15c; $1 / 41 \mathrm{~b}$., $40 \mathrm{c}$; lb., $\$ 1.50$, postpaid.

\section{4-EARLY FLAT DUTCH.}

The same type as the Giant, but not much earlier and not quite so large. Pkt., $5 \mathrm{c}$; oz., $15 \mathrm{c}$; $1 / 4 \mathrm{lb} ., 40 \mathrm{c}$; lb., $\$ 1.50$ postpaid.

\section{EXTRA EARLY ETAMPES}

One of the earliest cabbages and of conical shape. Pkt., $5 \mathrm{c}$; Oz., $15 \mathrm{c}$; $1 / 4$ lb., $40 \mathrm{c}$; $1 \mathrm{~b} ., \quad \$ 1.50$, postpaid.

\section{DRUMHEAD SAVOY.}

Leaves are crimped and wrinkled in a peculiar manner. Heads are large and solid. Pkt., 5c; oz., $15 \mathrm{c}$; $1 / 2$ lb., $50 \mathrm{c}$ $1 \mathrm{~b} ., \quad \$ 1.90$, postpaid.

\section{5-IMPROVED DANISH BALL-HEAD.}

The famous variety from Denmark. Not so large as Late Flat Dutcl but the best keeper in the world. Pkt., 5c: oz., $20 \mathrm{c} ; 1 / 4$ lb., $60 \mathrm{c}$; lb., $\$ 2.00$, postpaid.

\section{6-SUREHEAD.}

All head and always sure to head. The largest main crop variety of the Flat Dutch type. Pkt., $5 \mathrm{c}$; oz., $15 \mathrm{c}$; 1/4 1b., $40 \mathrm{c}$; Ib., $\$ 1.50$, postpaid.

\section{ALL SEASONS,}

A fine variety for any season, of good shape and size. Pkt., 5c; oz., 15c; 1/4 lb., 40c; $1 \mathrm{~b} .$. ; $\$ 1.50$

\section{7-BURPEE'S ALL HEAD EARLY.}

A week earlier than any of the early summer cabbages: the deep, flat heads are remarkably solid and uniform in color, as well as in shape and size: makes a fine winter color, as well as in shape and size; makes a fine winter

\section{8-HENDERSON'S EARLY SUMIMER.}

Heads large. round and very compact; ten days later than Jersey Wakefield; one of the earliest large heading varieties. Best American. Pkt., 5c; oz., 15c; 1/4 1b., 40c; lb., $\$ 1.50$.

\section{MAMMOTH RED ROCK}

The largest and surest heading red cabbage grown. Pkt. $5 \mathrm{c}$; oz., $20 \mathrm{c} ; 1 / 4$ lb., $50 \mathrm{c}$; $1 \mathrm{~b}$., $\$ 2.00$, postpaid.

\section{CHARLESTON WAKEFIELD.}

Extra early. large cone shaped head. Pkt., 5c; $1 / 4$ lb., $50 \mathrm{c}$; lb., $\$ 1.50$.

\section{HENDERSON'S SUCCESSION.}

The Market Gardener's Favorite. Pkt., 5c; 1/4 1b., 50c; lb., $\$ 1.50$.

\section{9-GLORY OF ENKHUIZEN (Imported).}

This is an excellent mid-summer variety. It comes in about a week earlier than All Seasons, makes a nice large head, has few outer leaves and can be planted close. Our tests show it to be worthy of a place among the new varieties of merit and we can recommend it as a good addition to the list. Pkt., 5c; oz., $20 \mathrm{c}$; $1 / 4$ lb., $75 \mathrm{c}$; 1b., $\$ 2.00$.

\section{0-COPENHAGEN MARKET (Imported)}

A new early variety, popular with market gardeners. It is one of the finest early round-headed cabbage in cultivation. It is desirable on account of the remarkable characteristic of maturing the heads all at the same time, enabling the grower cleaning of the cond about ten the land at the first cutting. The heads average small core. The leaves are light green, rather small, saucershaped and tightly folded, making it possible to set them close together in the field. Pkt., 5c; oz., 20c; $1 / 41 \mathrm{~b} ., 75 \mathrm{c}$; close togeth
lb., $\$ 2.00$.

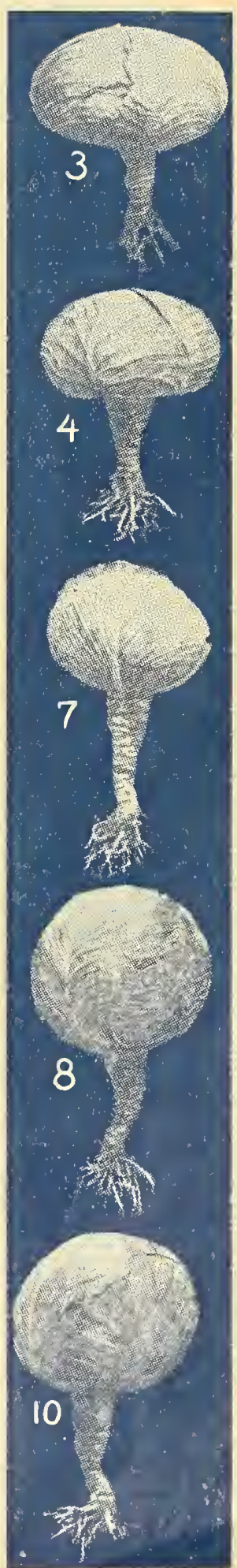


DILL

Tall German. Oz., 10c; 1/4 lb., 15c; 1b., $50 \mathrm{c}$.

EGG PLANT

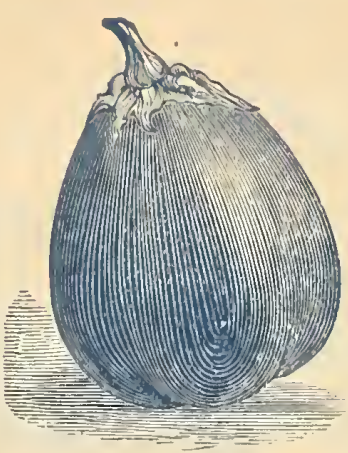

BLACK BEAUTY

I M P R V E D NEW YORK PURPLE SPINELESS.

Ver'y large and smooth. fine dark color. Ours is the spineless plant, most 1) referred by our market gardencrs, both East and West. Pkt., 5c; oz., 25c; $1 / 4$ lb. $80 \mathrm{c} ; 1 \mathrm{~b} ., \$ 3.00$.

\section{BLACK PEKIN}

A fine varicty, bearing large, round, deep, purple fruits, fine graincd, and of superior quality.

Plit., 50c; oz., $25 \mathrm{c} ; 1 / 4 \mathrm{lb}$.

EARLY LONG PURPLE.

Early, hardy and productive; excellent for the table. Plit., 5c; oz., 20c; $1 / 4$ lb., $70 \mathrm{c} ; 1 \mathrm{~b} ., \$ 2.50$.

Green Curled. Pkt., 10c: oz., 25c; 1/4 lb., $\$ 1.00$

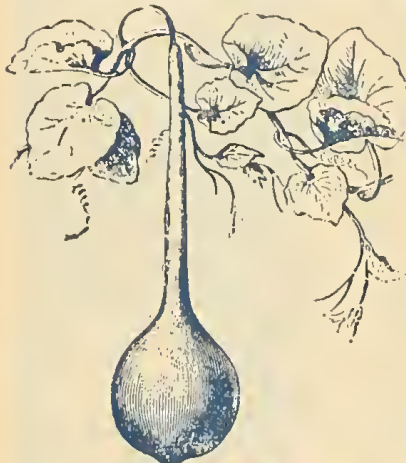

\section{GOURDS}

Pear. Pkt., 5c; oz.,

Dipper. Pkt., 5c; oz., $10 \mathrm{c}$.

Dishrag. Pkt., 5c; oz., $10 \mathrm{c}$.

Sugar Trough. Plst., 5c; oz., $10 \mathrm{c}$.

\section{Hercules Club. Plit.} c; oz., $10 \mathrm{c}$.

Egg. Pkt., 5c; oz.

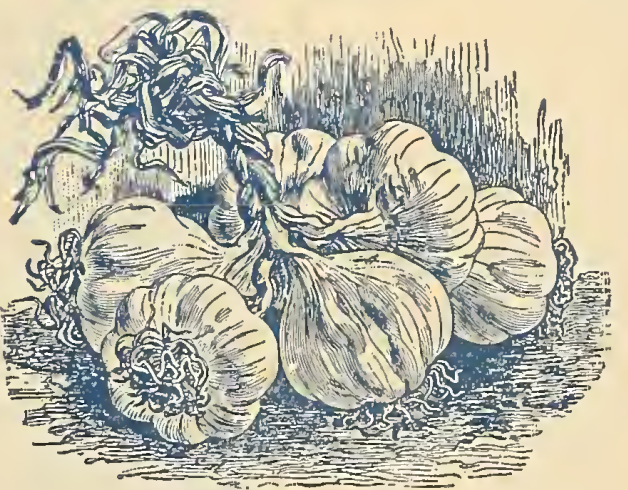

GARLIC

Mexican Top Sets................. lb. $25 \mathrm{c}$

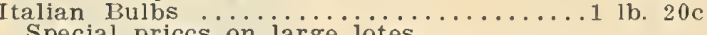

Special prices

KOHL RABI

EXTRA EARLT WHITE VIENNA.

Pkt., $10 \mathrm{c} ;$ oz., $40 \mathrm{c} ; 1 / 4$ lb., $\$ 1.50$.

LEEK

\section{LETTUCE}

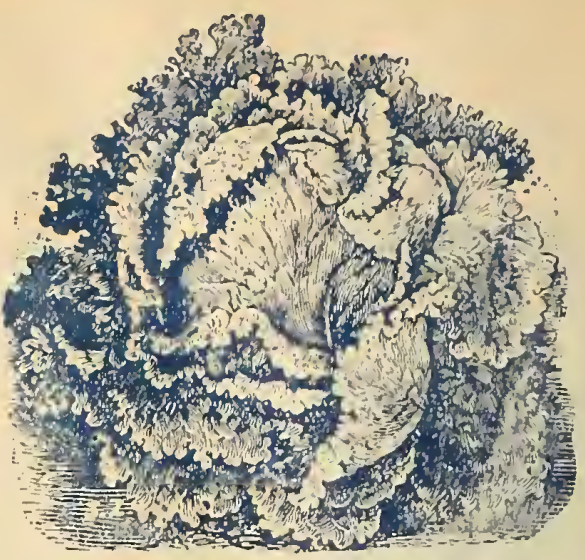

GRAND RAPIDS.

\section{GRAND RAPIDS.}

As a forcing and shipping lettuce this undoubtedly stands at the head; beautiful in appearance. Pkt., 5c: $1 / 4$ lb., 25c; 1b., $75 \mathrm{c}$

\section{HANSON IMPROVED.}

Always sure to make large, handsome heads of excellent quality; outer leaves green with light veins, inner leaves white. Pkt., 5c; 1/4 lb., 25c: lb., $75 \mathrm{c}$.

\section{BIG BOSTON.}

Desirable either for forcing in cold frames or open ground planting; always produces large, solid, salable heads. Pkt., 5c; $1 / 4 \mathrm{lb}, 25 \mathrm{c}$; 1b., $75 \mathrm{c}$.

\section{DENVER MARKET.}

Early, for forcing or open ground; heads large and solid; leaves crisp and tender, blistered like a Savoy Cabbage. most attractive in appearance. Pkt., 5c: $1 / 4$ lb., $25 \mathrm{c} ; 1 \mathrm{~b} ., 75 \mathrm{c}$.

\section{SIMPSON BLACK SEEDED.}

Nearly double the size of Early Curled Simpson: leaves delicate golden yeliow; for forcing or out of doors. Pkt., 5c; $1 / 4$ 1b., 25c; 1b., $75 \mathrm{c}$.

\section{SIMPSON EARLY CURLED.}

White secd. Pkt., 5c; $1 / 2$ lb., 25c; lb., $75 \mathrm{c}$.

ICEBERG.

New. of bcautiful appearance and excellent quality; leaves green, slightly tinged with red at the edge; heads good size. Pkt., 5c; 1/4 lb., 25c; lb., 75c.

\section{MAY KING.}

New. Heads extra large and solid; green outsidc but heart clear yellow; very desirable. Pkt., 5c; 1/4 Jb., $25 \mathrm{c} ; 1 \mathrm{~b} ., 75 \mathrm{c}$.

\section{CRISP AS ICE.}

Outside leaves varigated with dark brown and green. Heart rich creamy yellow. Pkt., 5c; 1/4 lb., $25 \mathrm{c} ; 1 \mathrm{~b} ., 75 \mathrm{c}$.

\section{EARLY NEW YORK.}

An early variety of head lettuce either for forcing or open ground. Large, solid heads, light green color, and is very slow to go to seed. Leaves beautifully marked and blistered, very crisp and tender. Pkt., 5c; oz., 10c; 1/4 1b., 25c; 1b., 75c.

IARGE IONDON. Oz., $10 \mathrm{c}$.

\section{MUSTARD}

\section{GIANT CURLED SOUTHERN.}

Highly esteemed for salads, particularly in the South. The leaves are twicec the size of the ordinary White Mustard; flavor sweet and pungent. Oz., $5 \mathrm{c} ; 1 / 4 \mathrm{lb}$., 15c; lb., 40c.

The leaves are long, ruffled and curled as gracetully as an ostrict plume. Is especially good as a salad and as greens cqual to spinach. The growtl of leaves makes it a very ornamental plant. Oz., $5 \mathrm{c}$ : $1 / 1$. $1 \mathrm{~b} ., 15 \mathrm{c}: 1 \mathrm{~b}, 40 \mathrm{c}$

\section{CHINESE}

$\Lambda$ very hardy variety. Leaves are large, thick and deeply savoyed with broad white mid-rib. Pkt., $5 \mathrm{c}$ $1 / 4$ lb., 15c; $1 \mathrm{~b} ., 40 \mathrm{c}$.

\section{BLACK OR BROWN.}

The common, small seeded variety. More pungent than the white. Oz., 5c; $1 / 4$ lb., $15 \mathrm{c} ; 1 \mathrm{~b} .40 \mathrm{c}$.

\section{WHITE ENGLISH.}

Leaves are light oreen mild and tender when young: seed light yellow. $2 ., 5 \mathrm{c} ; 1 / 4 \mathrm{lb}, 15 \mathrm{c} ; \mathrm{lb}, 40 \mathrm{c}$ 


\section{Musk Melons--_Cantaloupes Grow "Honey Dew" Melons}

THE SWEETEST MELON EVER GROWN.

First introduced in the West in 1915 , and is fast becoming a favorite.

The rind is a dull white when ripe. Part of the melons show like a tendency to net. This appears when the melon is ready to pick.

The size runs six to seven inches in diameter from top to bottom a $\mathrm{nd}$ eight inches in length. The matured melons are practically all the same shape and size.

The flesh is a rich green and very sweet. The melon is the best of all shippers and will keep several weeks so there is practically no in shipping.

I recommend this melon to market growers. The vines are vigorous and set si xto ten melons to the hill and if proper care is taken to ship only ripe melons a fine market can be established. My supply of seed is strictly right and grown from carefully selected stock seeds. Price, per pkt., 5c; oz., $20 \mathrm{c} ; 1 \mathrm{~b} ., \$ 2.50$.

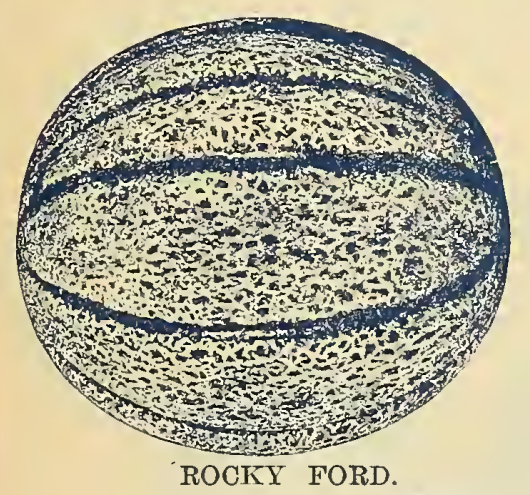

\section{GENUINE ROCKY FORD.}

JENNY LIND.

The earliest of the green fleshed sorts, and one of the sweetest. It is of flattened form, small size. $1 / 4$ oz., $5 \mathrm{c} ;$ oz., $10 \mathrm{c} ; 1 / 4,1 \mathrm{~b} ., 20 \mathrm{c}$ It 1 is $75 \mathrm{c}$.

\section{EMERATD GEM.}

Excellent quality, is of medium size; skin ribbed though perfectly smooth and of deep emerald green color. Flesh salmon color thick, very juicy; flavor sweet and luscious. Melons mature extremely early. $1 / 2$ oz., $5 \mathrm{c}$; oz., $10 \mathrm{c} ; 1 / 4$ 1b., $20 \mathrm{c}$; $1 \mathrm{~b}$., $75 \mathrm{c}$.

\section{HACKFNSACK.}

Green flesh. A large, round variety, flattened at both ends and Green flesh. A large, round variety, flattened
well ribbed. $1 / 2$ oz., 5c; oz., 10c; 1/4 1b., 20c; 1b., $75 \mathrm{c}$.

\section{EXTRA EARLY HACKENSACK.}

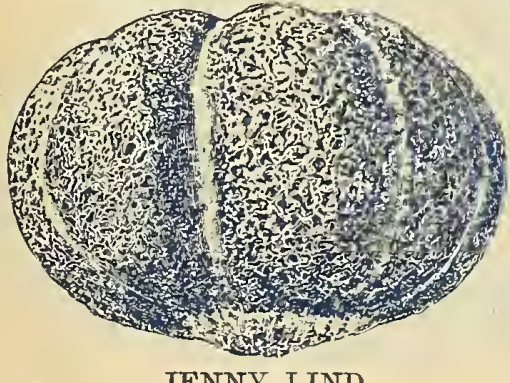

Green flesh. The new form is about ten days earlier than the old Hackensack, of almost equal size. $1 / 2$ oz., $5 \mathrm{c}$; oz., 10c; $1 / 41 \mathrm{~b} ., 20 \mathrm{c}$; lb., $75 \mathrm{c}$.

\section{PAUI ROSE.}

A new sort, possessing several characteristics of the Osage; form slightly oblong, distinctly ribbed, slightly netted; color, when unripe a deep green, turning a golden tini; flesh salmon, and so thisk as to show an unusually small seed cavity: flavor like Osage. Pkt.. c: oz., $10 \mathrm{c}$; $1 / 4$ lb., $20 \mathrm{c}$; $1 \mathrm{~b} ., 75 \mathrm{c}$

\section{TIP TOP.} A new melon of recent introduction and very deserving. All who sweet. Pkt., 5c; oz., 10c; $1 / 4$ 1b., 20c; 1b., $75 \mathrm{c}$. 


\section{OSAGE, OR MILLER'S CREAM}

A remarkably fine variety, and a very profitable sort for market gardeners, as it is fully established as a standard sort and will ever remain so. It is of medium size, oval in form, dark green in color. handsomely netted and slightly ribbed. The flesh is extremely and uniformly thick, of firm texture, rich salmon in color; highly flavored and delicious to the rind. Pkt, 5c: $0 \%, 10 \mathrm{c} ; 3 / \mathrm{b}$ 1b. 20c: 1b), 75c

\section{HOODOO.}

A new melon with many good qualities. Its size is about that of the popular Rocky Ford, which appeals to the shipper, while the delicate flavor of the thick, red flesh should commend it to every private gardener, Pkt., $5 \mathrm{c} ; 0 \mathrm{z}, 10 \mathrm{c} ; 1 / 4 \mathrm{lb}, 20 \mathrm{c} ; \mathrm{lb}, 75 \mathrm{c}$.

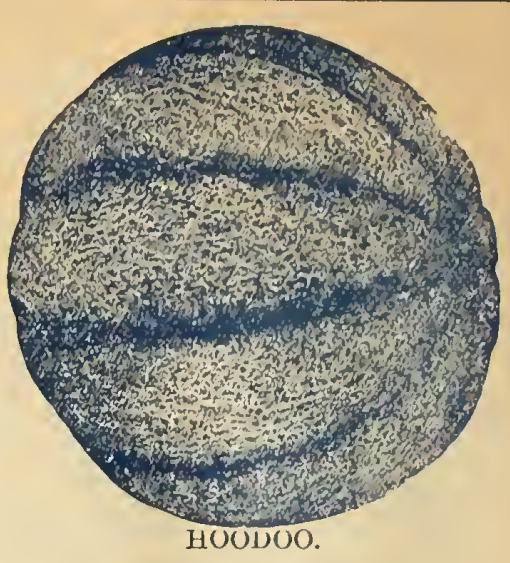

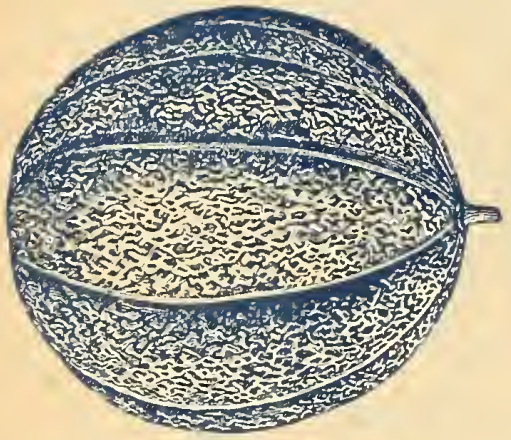

OSAGE-MILLER'S CREAM.

\section{BANANA.}

An entirely distinct variety, bearing long, slender banana-like fruit. Flesh deep salmon color, thick and of good quality, I'kt, 5c, oz., 10c; $1 / 4$ lb, $25 \mathrm{c}$; lb., $80 \mathrm{c}$.

\section{MANGO MELON, OR VINE PEACH.}

About the size of an orange, sometímes called "Orange Melon." Fine for sweet pickles or preserves. Pkt, $5 \mathrm{c}$; oz, $15 \mathrm{c}$.

\section{GARDEN LEMON.}

Similar in size and habit of growth to Mango Melon, but with sharper flavor, Pkt, 5c; oz., $15 \mathrm{c}$.

\section{CASABA, OR LEMON PERSIAN.}

Long, oval shaped, skin very thin and delicate; flesh extremely Long, oval shaped, skin very thin and delicate; flesh
tender, rich and sweet. Pkt, 5c; oz 10c. $1 / 4$ lb., 20c; $1 \mathrm{~b} ., 75 \mathrm{c}$.

\section{Genuine Tom Watson Water Melon}

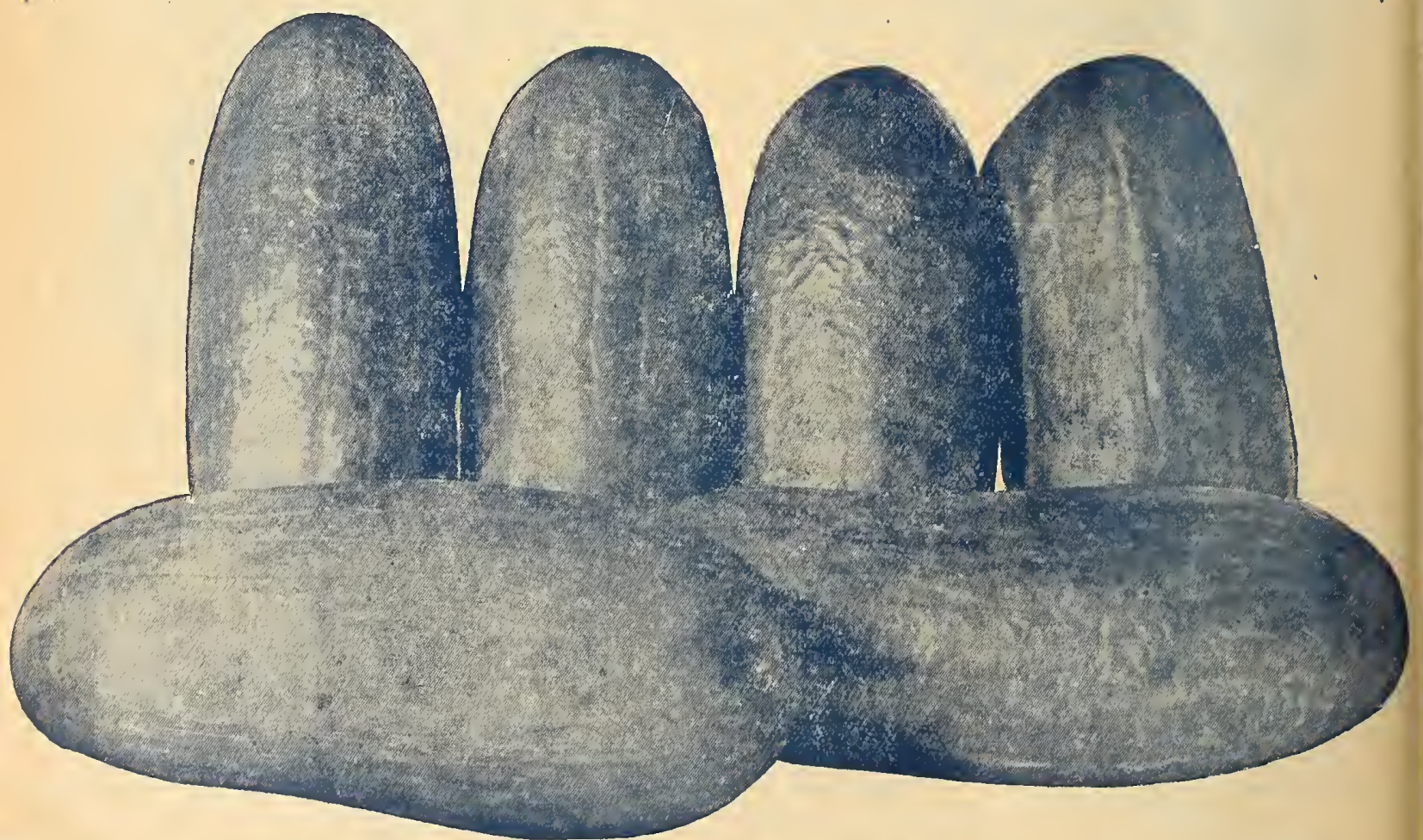




\section{WATERMELONS}

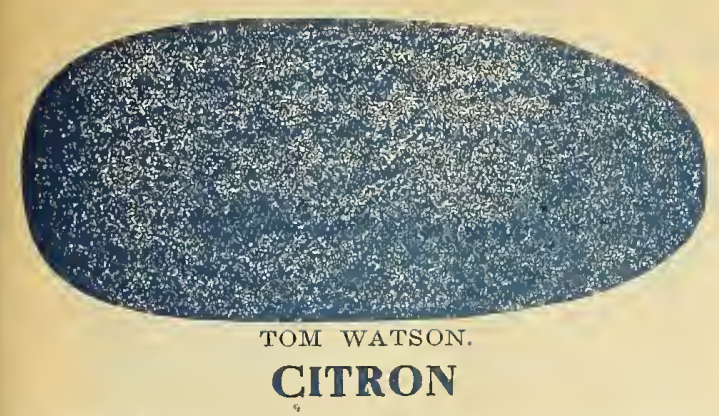

Green seeded. Pkt., 5c; oz., 10c; 1/4 1b., 15c; 1b., Red seeded. Pkt., 5c; oz., 10c; $1 / 4$ lb., 15c; 1b., $60 \mathrm{c}$.

\section{PHINNEY'S EARLY.}

This is another very early melon, earlier than the preceding; extensively cultivated in the North. Pkt., 5c; oz., 10c; 1/4 lb., 15c; lb., 60c.

MCIVER'S SUGAR.

Flkt., $5 \mathrm{c}$; oz., 10c; $1 \mathrm{~b}, 60 \mathrm{c}$.

\section{MONTE CHRISTO.}

Plit., 5c; oz., 10c; 1/4 lb., 15c; 1b., 50c. TRIUMPH.

Pkt., 5c; oz., 10c; $1 / 41 \mathrm{~b} ., 15 \mathrm{c} ; 1 \mathrm{~b} ., 50 \mathrm{c}$. DIXIE.

Pkt., 5c; oz., 10c; $1 / 41 \mathrm{~b} ., 15 \mathrm{c} ; 1 \mathrm{~b} ., 50 \mathrm{c}$. DUKE JONES.

Pkt., 5c; oz., 10c; $1 / 4$ 1b., 15c; 1b., $50 \mathrm{c}$ CAROLINA BRADFORD.

Pkt., $5 \mathrm{c}$; oz., $10 \mathrm{c} ; 1 / 4 \mathrm{~b} ., 15 \mathrm{c}$; $1 \mathrm{~b} ., 50 \mathrm{c}$. LIGHT ICING.

Pkt., 5c; oz., 10c; $1 / 4$ lb., $15 \mathrm{c} ; 1 \mathrm{~b} ., 50 \mathrm{c}$.

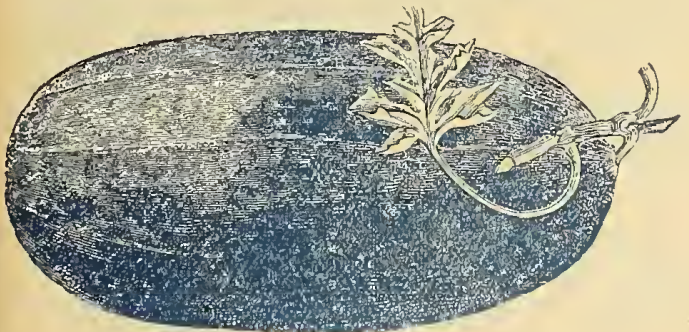

\section{KLECKLFY'S SWEET}

Sweetest Watermelon in the world; large, oblong shape. Skin dark green; rind very thin and brittle; fully ripe melon will always split ahead of the knife. Flesh bright scarlet, sugary and melting in
the highest degree. Heart is broad and solid. This melon is not a good shipper, but is the finest table variety and for home market. We have the true genuine stock, which is very hard to obtain. Plkt..

\section{GFORGIA RATTLESNAKE.}

Excellent market variety; large, oblong; rind dark mottled and striped; a well-known shipping melon. Plkt., 5c; Oz., $10 \mathrm{c} ; 1 / 4 \mathrm{~b}$., $20 \mathrm{c}$; $1 \mathrm{~b} ., 50 \mathrm{c}$.

\section{HALBERT HONEY.}

Skin dark green, flesh crimson; very sweet. Fine for use in the North. Pkt., 5c; oz., 10c; $1 / 4$ 1b., 20c; lb., $50 \mathrm{c}$.

\section{ICEBERG.}

Similar in shape and size to Kolb Gem, but darker in color. Pkt., 5c; oz., 10c; 1/4 1b., $20 \mathrm{c}$; 1b., $50 \mathrm{c}$.

Black Boulder (or Black Diamond.-Pkt., 5c; oz., $10 \mathrm{c} ; 1$ lb., $60 \mathrm{c}$. postpaid.

Wonderful Sugax-Plit., 5c; oz., 10c; 1 lb., $60 \mathrm{c}$, postpaid.

Peerless (or Icecream).-Pkt., 5c; oz., 10c; 1 lb., $60 \mathrm{c}$, postpaid.

Dark Icing.-Plkt., 5c; oz., 10c; 1 lb., 00c, postpaid.

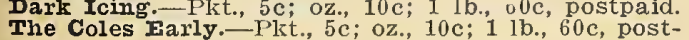
The Coles Early.-Plit., 5c; oz., 10c; 1 lb., 60c, post-

Mrountain Sweet.-Pkt., 5c; oz., 10c; 1 lb., 60c, postpaid. Ford Hook Early.-Pkt., 5c; oz., 10c; 1 lb., 60c, pospaid.

\section{TOM WATSON WATERMIELONS.}

No melon ever offered commands so high a price as the Genuine Tom Watson in the leading markets of the North. It finds a ready sale at from $\$ 10$ to $\$ 25$ per car more than other varieties; while less attractive kinds sit around on the tracks unsold.

We make a specialty of growing this melon for seed purposes and have a true strain of the Original TOM WATSON

The melons from which we take our seed weigh from twenty to forty pounds or more.

The true type of this melon seed is buff, or a very light brown. A great many seed houses are sending out white seeds for the true strain of Tom Watson This shows a degeneration st the melon and will not give you the results desired. Plant the true strain. We have it. Price, pkg., 5c; oz the true strain. We have
$10 \mathrm{c} ; 1 / 4$ lb., $20 \mathrm{c} ; 1 \mathrm{~b} .60 \mathrm{c.}$

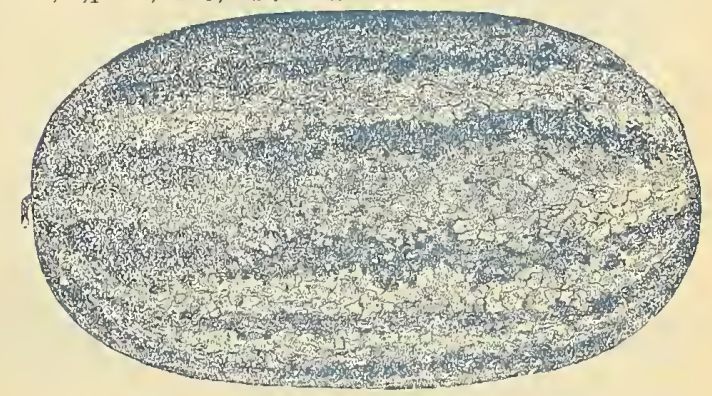

ALABAMA SWEET.

A large dark-skinned melon, flesh red. One of the first to come into the market, being early, and of strong growth and will bear longer than any other melon. It is a light seeded melon and first-class for shipping. Good size, though not ungainly. Largely raised in Texas, where it brings extra. prices. Pkt., 5c; oz., 10c; 1/4 lb., 20c; $1 / 2$ lb., $35 \mathrm{c}$; prices., $60 \mathrm{c}$, postpaid. KOLB GEM.

More largely grown in the South than any other melon; as a shipping variety has no superior: rind dark green mottled with lighter shades; nearly round; quality superb. Pkt., 5c; oz., 10c; $1 / 41 \mathrm{~b}$., $20 \mathrm{c}$; lb., 50c. FLORIDA FAVORITE.

Highly prized for its delicious flavor; oblong in shape and grows to a very large size; rind dark green with stripes of lighter green; ten days earlier than Kolb Gem. Pkt., 5c; oz., 10c; 1/4 1b., 20c; b., 50c. JORDAN'S GRAY MONARCH,

Pkt., 5c; ob., 10c; 1/4 Ib., $20 \mathrm{c} ; 1 \mathrm{~b} ., 50 \mathrm{c}$.

KENTUCKY WONDER.

Pkt., 5c; ob., 10c; $1 / 4$ 1b., 20c; lb., $50 \mathrm{c}$.

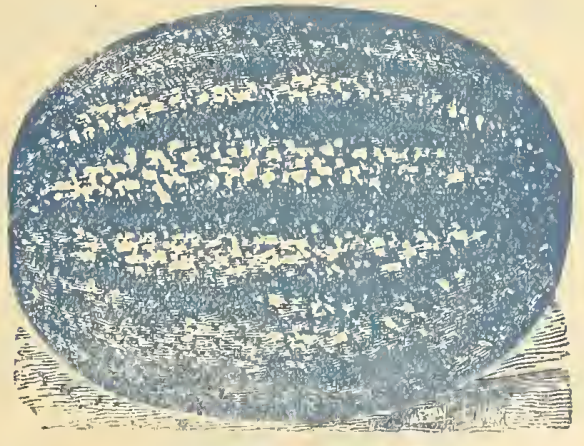

HARRIS EARLIEST.

It is superior to other early sorts. This melon will bring greater profits to the market gardener, because of its extreme earliness and size enables you to be first in the marliet and get the top prices.
Pkt., 5c; oz., 10c; $1 / 4$ b., 20c; 1b., 60c.

\section{SWEETHEART.}

Globular in shape; skin very bright, mottled green; flesh bright red, firm and heavy, but exceed-
ingly sweet. Pkt., 5c; oz., 10c; $1 / 4$ lb., 15c; 1b., $60 \mathrm{c}$.

\section{GOLDEN HEART}

A fine melon of rich sweet yellow flesh. Pkt., 5c; oz., $10 \mathrm{c}$; 1b., 75c. 


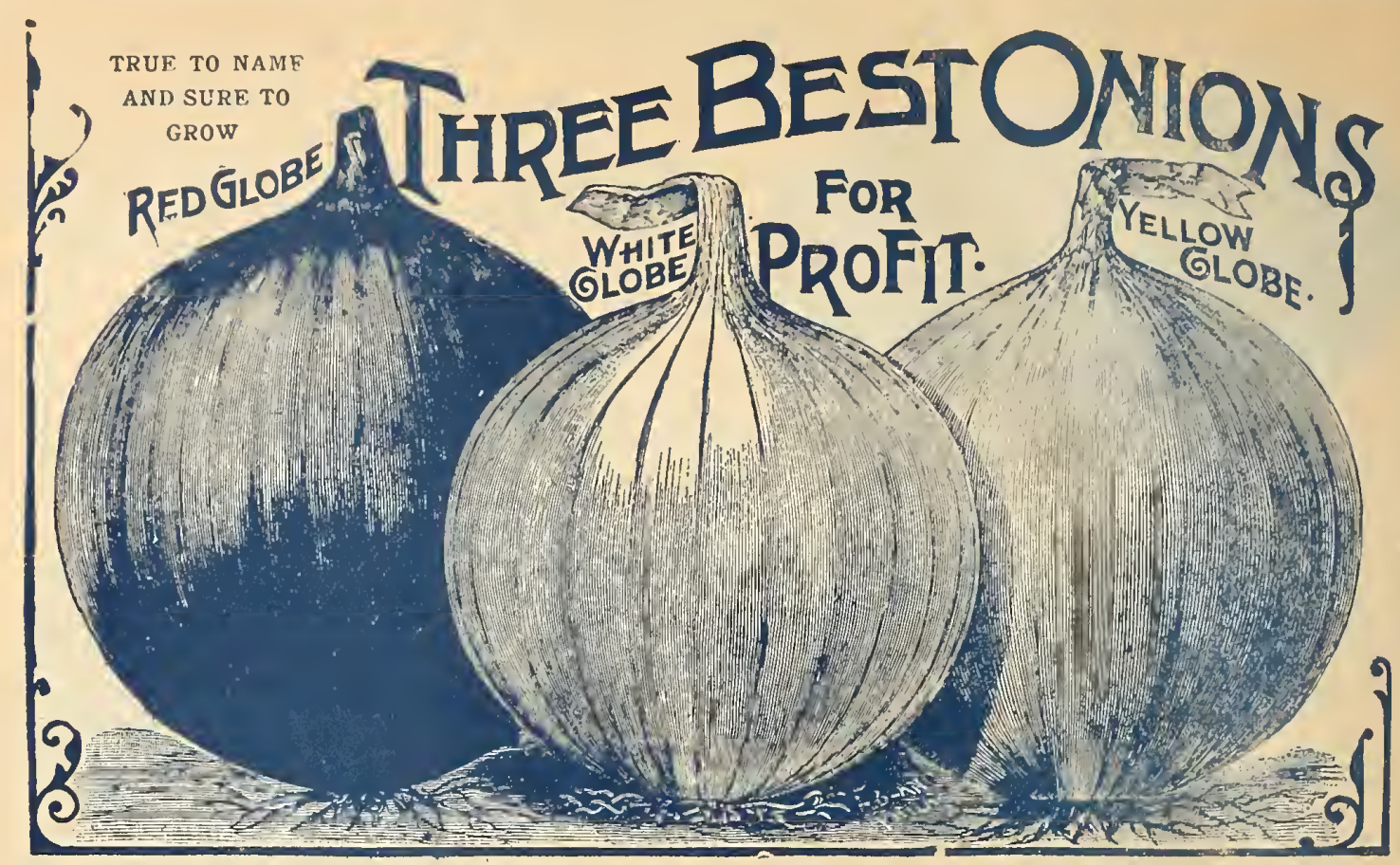

\section{NORTHERN GROWN ONION SEED OF SUPERIOR QUALITY}

SOUTHPORT YELLOW GLOBE.

A large, perfectly shaped Globe onion and an excellent onion for keeping throughout the winter A very heavy cropper, handsome in appearance and a good dark yellow color. Pkt., $5 \mathrm{c} ;$ oz., $15 \mathrm{c} ; 1 / 4 \mathrm{lb}$.,
$40 \mathrm{c} ; 1 \mathrm{~b} ., \$ 1.50$.

\section{YELLOW GLOBE DANVERS.}

This fine onion is of large size. An early and abundant cropper. Bulbs very thick, flat or slightly convex bottoms, full oval top with small neck and
rich brownish yellow skin. Pkt, $5 \mathrm{c} ;$ oz., $15 \mathrm{c}$; $1 / 4 \mathrm{lb}$., $40 \mathrm{c} ; 1 \mathrm{~b} ., \$ 1.50$.

\section{SOUTHPORT RED GLOBE.}

This is a fine keeper. Large size and considered one of the best of the red onions. Flesh is fine grained, very mild and tender. Pkt., $5 \mathrm{c}$; oz.. $20 \mathrm{c}$; grained, very mild a

\section{SOUTHPORT WHITE GLOBE.}

This glows to a very large size and is a perfectly globe-shaped onion. Color is a clear pure white. This variety is used by the Chicago market gardeners for bunching. Pkt., 5c; oz., 20c; $1 / 4$ lb., $60 \mathrm{c} ; 1 \mathrm{~b} ., \$ 2.00$

\section{PRIZETAKER}

(irows to an immense size and for fall marketing is unexcelled. Although of such great size, it is very hardy and a fair winter kecper, as it ripen up liard and firm; very fine grained, and of mild, delicate flavor. The outside skin is rich yellow while the flesh is white. Pkt., 5c; oz., 15c; 1/4 lb., $40 \mathrm{c}$; $1 \mathrm{~b}, \$ 150$

\section{BERMUDA RED.}

A very early pale red onion, grown extensively in the Bermudas and southern part of the United States for early shipping to Northern markets. Pkt. $5 \mathrm{c}$; Oz., 20c; $1 / 4$ lb., $60 \mathrm{c}$; $1 \mathrm{~b} ., \$ 2.00$.

\section{BERMUDA WHITE.}

or otherwise same as red. Pkt., 5c; oz., 20c; $1 / 4$ lb., 60c; $1 \mathrm{~b} ., \$ 2.00$.

\section{LARGE RED WETHERSFIELD.}

We have a very fine and select strain of this sort. Color is deep purplish red, flesh white moderately grained and very firm. Yields an enormous amount per acre, and is one of the best winter keeping onions. Pkt., 5c; oz., 15c; 1/4 lb., 40c; lb., $\$ 1.25$.

\section{EXTRA EARLY FLAT RED.}

This varipty matures from ten days to two weeks earlier than the Red Wethersfield. The color is a deep rich red, fine grain and close. Pkt., 5c oz., 15c; $1 / 4$ lb., $40 \mathrm{c}$; lb., $\$ 1.50$.

\section{AUSTRALIAN BROWN ONION.}

Is of medium size, wonderfully hard and solid and most attractive for market, both as to form and appcarance. The color of the skin is a clear amber prown. Pkt., 5c; oz., 15c; $1 / 4$ lb., $40 \mathrm{c} ; 1 \mathrm{~b} ., \$ 1.50$.

\section{WHITE PORTUGAL.}

American Silver Skin. This is the best sort to sow-for onion sets or for pickling. When sown hickly for either it makes a small, round. hard bulb. Pkt., 5c; oz., 15c; 1/4 1b., 60c; 1b., $\$ 2.00$.

\section{PHILADELPHIA SILVER SKIN.}

Very desirable for family use. Flavor mild and pleasant. Plit., 5c; oz., $15 \mathrm{c}$; $1 / 1$ lb., 60c; lb., $\$ 2.00$.

\section{WHITE BARLETTA.}

When matured the tops die down, leaving beautiful and perfect little bulbs. The color is pure white, flavor mild and delicate, perfectly adapted for pickling and table use. Pkt., $5 \mathrm{c} ;$ oz., $15 \mathrm{c} ; 1 / \mathrm{s} \mathrm{lb}$., $60 \mathrm{c}$ : lb. $\$ 2.00$.

CRYSTAL WHITE WAX.

This variety is popular at the South where the transplanting method of culture is practiced. A large, beautiful, silvery white skinned variety, of ity. Pkt, 5c; oz., 25c; 1/4 lb., $75 \mathrm{c}$; lb., $\$ 2.75$.
We have some fancy Onion Sets this season and chave you money on them.

Fancy Red Globe Sets, per 1b., 20c; per bu., $\$ 3.00$ Fancy White Globe Sets, per 1b., $20 \mathrm{c}$; per bu., $\$ 3.00$ $\$ 2.50$.

Fancy Multipliers Sets, White, per 1b., 20c; per bu., $\$ 5.00$.

Fancy Top Sets (winter), per lb., 15c; per bu. $\$ 1.50$.
Don't Delay in Ordering Onion Sets or Seed IT IS SCARCE. 


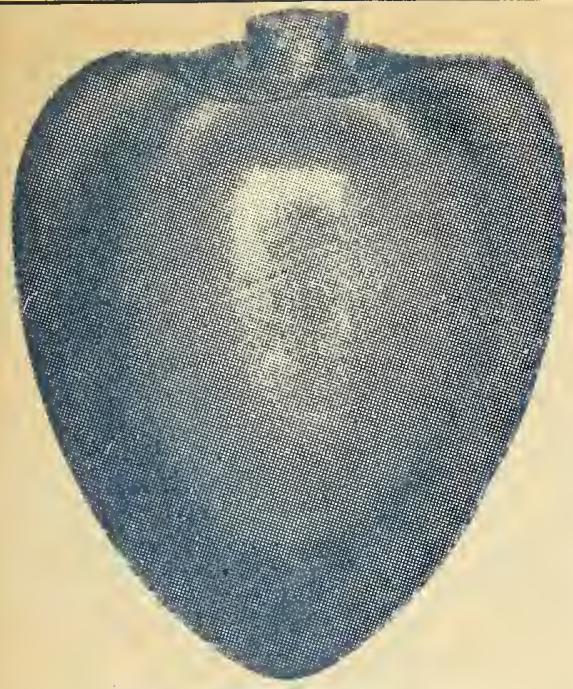

NEW PERFECTION PEPPER. Half of Original Size.

\section{OKRA OR GUMBO}

The young seed pods of this Southern plant are used for the well known and delicious "Gumbo" soups, alone or with chicken. WHITE VELVET.

Produces pods larger than any other. Plkh., 5c; $1 / 4$ lb., 20c lb., $75 \mathrm{c}$

DWARF GREFN.

Grows "low but stocky and is very productive. Pkt., 5c; $1 / 4 \mathrm{lb}$. $20 \mathrm{c} ; 1 \mathrm{~b} ., 75 \mathrm{c}$.

\section{PEPPERS}

\section{PERFECTION.}

of the Pimento type, sweet and large, deep green and when ripe of deep scarlet. Meat two or three times thicker than other varieties. Outyields all others. Pkt., 5c; oz., 35c; 1/4 1b., $\$ 1.50$ Ib., $\$ 5.00$.

\section{LARGE BELI OR BULL NOSE.}

A very large sort of inverted bell shape, suitable for filling or for a mixed pickle Flesh thick, hard and less pungent than most other sorts. Pkt., 5c; oz., $20 \mathrm{c} ; 1 / 1$ 1b., $75 \mathrm{c}$; 1b., $\$ 2.50$.

\section{SWEET MOUNTAIN.}

Plants are very vigorous and productive, growing upright, with moderately large leaves. Fruit very large, long, often 8 inches or more in length by 2 inches in diameter. Plkt. $5 \mathrm{c} ; \mathrm{z} .15 \mathrm{c}, 1 / 1 \mathrm{~b}$ $50 \mathrm{c} ; 1 \mathrm{~b} ., \$ 1.75$.

\section{RUBY KING}

An improved American sort, reaching the largest size, yet retaining the symmetrical shape of the smaller sorts. Plit, 5c: oz. $20 \mathrm{c} ; 1 / 4$ 1b., $75 \mathrm{c}$; 1b., $\$ 2.50$.

\section{CHINESE GIANT PEPPER.}

Writhout doubt one of the very best and largest Mango Peppers ever introduced. Its mammoth size, splendid shape, beautiful, rich, glossy-red flesh and mild flavor, all lead us to speak of it in words of commendation. Pkt., 5c; oz., 25c; 1/4 lb., $\$ 1.00 ; 1 \mathrm{~b} ., \$ 3.50$.

\section{MAMMOTH GOLDEN QUEEN.}

One of the largest handsomest and most productive varieties: color bright golden yellow; large as Ruby King; flavor mild and

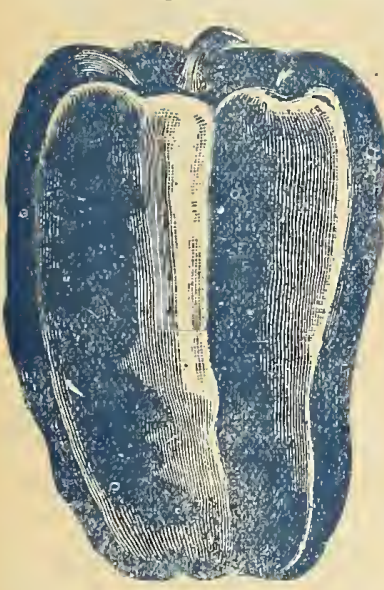

NEW MAMMOTH pleasant Pkt. $5 \mathrm{c} ; 0 \mathrm{z}, 15 \mathrm{c}$; $1 / 4$ 1b. $50 \mathrm{c}$ : pleasant. $\$ 1.75$.

\section{SWEET SPANISH MONSTROUS.}

A very large variety and mild flavored. Pkt., 5c; oz., $15 \mathrm{c} ; 1 / 4$ 1b., $50 \mathrm{c} ; 1 \mathrm{~b}$.

\section{LONG RED CAYENNE.}

A long, slim, pointed pod, and when ripe, of a bright red color. Fxtremely strong and pungent. Pkt., 5c; oz., $20 \mathrm{c}$; $1 / 1$ lb. $75 \mathrm{c} ; 1 \mathrm{~b} ., \$ 2.50$.

\section{RED CHILI.}

Used in the manufacture of pepper sauce. Plit., 5c; Oz., 20c; 1/4 1b., $75 \mathrm{c}$; lb., $\$ 2.50$.

\section{RED CLUSTER.}

A new type of Chili, with upright bright red fruits. Pkt., $5 \mathrm{c}$; oz., $20 \mathrm{c}$; $1 / 4$ lb., $75 \mathrm{c} ; 1 \mathrm{~b} ., \quad \$ 2.50$

\section{CELESTIAL.}

A Chinese variety bearing roundish upright pods. Plit., 5c; oz., 20c; $1 / 4 \mathrm{lb}$. $75 \mathrm{c}$ : ib., $\$ 2.50$.

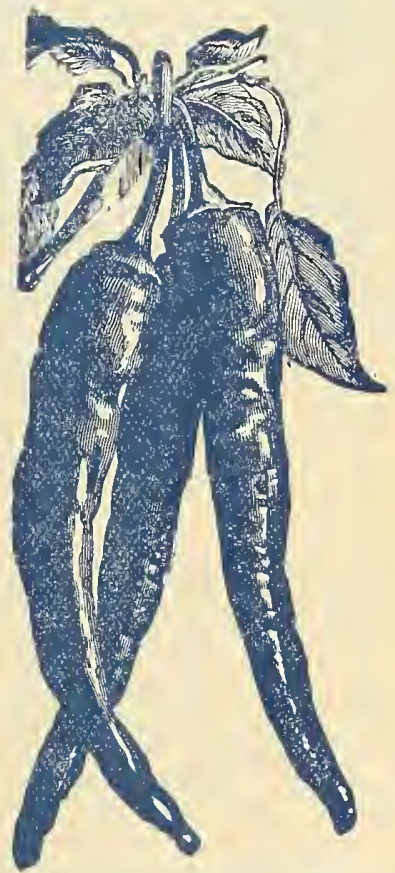

LONG RED CAYENNE.

\section{PARSNIPS.}

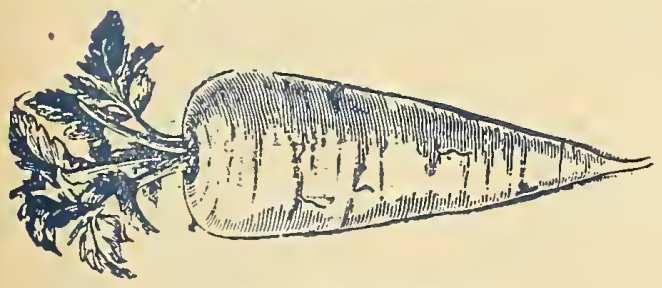

HOLLOW CROWN.

Roots long, smooth, tender, sugary and of most excellent flavor. Pkt., 5c; $1 / 4$ lb., $15 \mathrm{c} ; 1 \mathrm{~b} ., 50 \mathrm{c}$

\section{GUERNSEY.}

Roots white, very tender, with a smooth, clean skin. Plkt., 5c; 1/4 lb., $15 \mathrm{c} ; 1 \mathrm{~b} ., 50 \mathrm{c}$.

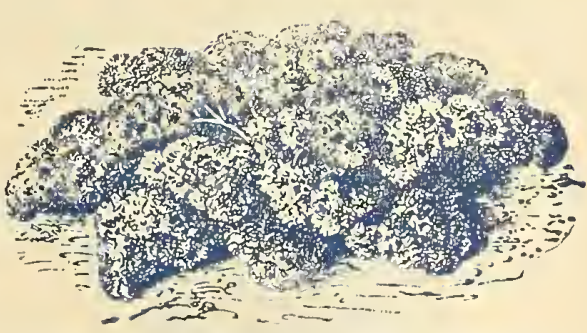

CHAMPION MOSS CURLED PARSLEY.

CHAMPION MOSS CURLED.

A vely fine curled variety. One of the handsomest for garnishing purposes. Pkt., $5 \mathrm{c}$; oz., $10 \mathrm{c} ; 1 / 4 \mathrm{lb}$. $25 \mathrm{c} ; 1 \mathrm{lb} ., 75 \mathrm{c}$

\section{DOUBLE CURLED.}

The standard sort for outdoor culture, Pkt., 5c: oz., $10 \mathrm{c} ; 1 / 4$ lb., $25 \mathrm{c} ; 1 \mathrm{~b} ., 75 \mathrm{c}$ 


\section{PEAS OF ALL KINDS}

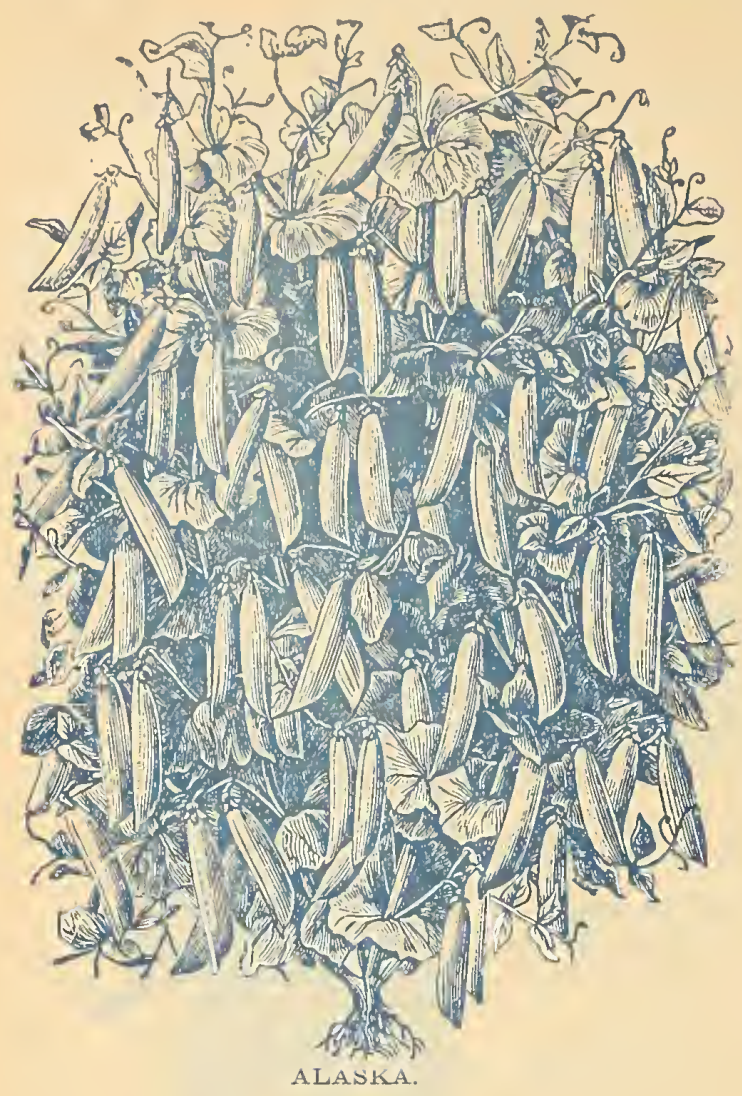

ALASKA.

Well known and extensively used. Very early and when carefully grown, uniform in ripening. Vine is strong and vigorous, 2 to $21 / 2$ feet high, pods $21 / 4$ to $23 / 4$ inches long. Is ready for picking 50 days from $20 \mathrm{c} ; 2 \mathrm{lbs}$., $35 \mathrm{c}$, postpaid. $1 / \mathrm{s}$ bu., $\$ 1.50$; bu., $\$ 5.25$.

\section{GEMS, PREMIUM.}

Stron gand vigorous, producing vines from 18 to 4 inches in height. Pods are almost straight $21 / 2$ to $23 / 4$ inches long. Ready to pick 61 days from Per lb., $20 \mathrm{c} ; 2$ lbs., $35 \mathrm{c}$, postpaid. $1 / 1 / 4$ bu., $\$ 1.50$; bu., $\$ 5.50$.

\section{GEMS, MCLEAN'S LITTLE.}

Strong and vlgorous in growth, producing vines rom 18 to 24 inches in height. Pods are almost straight, $2 \frac{1 / 2}{2}$ to $23 / 4$ inches long. Ready to pick 61 medium in size Per lbee $20 \mathrm{c}$. 2 lbs., $35 \mathrm{c}$, postpaid. $1 / 4$ bu., $\$ 1.75$; bu., $\$ 6.00$.

\section{AMERICAN WONDER.}

Vigorous, produetive vines, from 9 to 12 inches high. On account of its dwarf habit of growth it is very desirable for private garden use. Pods $21 / 2$ inches long. Fit for cooking 55 days from planting. Seed is wrinkled. green, medium in size and square at ends. Per 1b., 20c; 2 lbs., 35c, postpaid. 1/4 bu.,

FIRST AND BEST.

Early, productive and hardy with a strong, vigorous vine, which is light in color and uniform in growth, $21 / 2$ to 3 feet in height and bearing straight pods 21 to 23 inches long. Is fit for table use 5 : pods $21 / 2$ ta 20 inches white in color. Per ib., 20e; 2 lbs., $35 \mathrm{c}$, postpaid. $1 / 4$ bu., $\$ 1.50$; bu., $\$ 5.25$.

\section{NOT'S EXCELSIOR.}

Resembling Gems in hablt, but more dwarf and uniform in growth, height 12 to 17 inches. Pods $21 / 2$ inches long. Fit for picking 56 days from plantsquare at ends. Per lb., 20e; 2 lbs., 35, postpaic $1 / 4$ bu. $\$ 1.75 ;$ bu. $\$ 6.00$.

\section{LEONARD'S POTLATCII.}

Strong, vigorous vines of even growth, 20 to 24 inches in lreight, with luxuriant dark foliage, bearing porls rredium green in color $3 \frac{1 / 2}{2}$ to 4 inches in length. No varicty known will produce more pods,

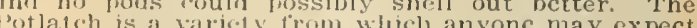
kreat things. Fit for talble usc 61 days from planting. seed gremll, Wrinkled, larke in size. Per lb.,

\section{GRADUS.}

A large, wrinklerl, early pea with a pod nearly as large as Telephone, filled with large peas, tender and of good qualilty and flavor. Very quick to germinate and mature with lise eally sorts. Seed must lo planted after all danger of early frost has passed. 11erght of vine 26) to 30 inches: pods 4 to $4 \frac{1}{2}$ inches in length. Seed wrinkled and of xxcellent quality. Fer 1ls., 20c: 2 lbs., 35c, postpaid. $1 / 4$ bu., \$1.75;

\section{STRATEGEM.}

vigorous, hardy and luxuriant vine, bearing arcre pods containing pees of cxccllent quality. heavy cropper. Vines 20 inches. Pods $3^{1 / 2}$ inches long. Fit for table use 56 days from planting. Seed very large, green, wrinkled. Per 1b., $20 \mathrm{c} ; 2$ lbs.. $35 \mathrm{c}$, postpaid. $1 / 4$ bu., $\$ 1.75$; per bu., $\$ 6.50$.

\section{HORSFORD'S MARKET GARDEN.}

Strongly resembling Premium Gen in habit of growth but about one-third taller. Vines growing 26 to 30 inches high. Pods about $2 \frac{1}{2}$ inches long. Fit fol picking 68 days from planting. Seed green, lb., $20 \mathrm{c} ; 2$ lbs., $35 \mathrm{c}$, postpaid. $1 / 4$ bu., $\$ 1.75$; per bu., $\$ 6.00$.

\section{PRIDE OF THE MARKET.}

of fine growth and general appearance, both vine and pod, and closely resembles the Strategem except that the vine is not quite so long and the pods are deeper green in color. The vine is 20 inches high, foliage dark green color. Pods are $31 / 2$ inches long, broad and dark in color. Fit for table use 61 days from planting. Seed blue, slightly dented, large. Per ib., 20c; 2 lbs., 35c, postpaid. Per $1 / 4$ bu., $\$ 1.75$

\section{CHAMPION OF ENGLAND.}

Strong and vigorous in growth, 42 to 50 inches in height. Pods $2 \frac{1}{2}$ to 3 inches long. Ready to pick 73 days from planting. Seed large, green, very much wriykled. Per lb, $20 \mathrm{c}$

\section{EVERBEARING.}

Vigorous and branching in habit of growth. Height 26 to 3 feet. Pods $23 / 4$ to 3 inches long. I'it to pick 70 days from planting. Seed green, wrinkled, large in size. Per lb., $20 \mathrm{c} ; 2$ lbs., $35 \mathrm{c}$, postpaid.
$1 / 4$ bu., $\$ 1.75$; per bu., $\$ 6.00$.

\section{TELEPHONE.}

Vines and leaves large and coarse. Height 40 to 50 inches, pods $41 \%$ inches long. Fit to pick 65 days from planting. Seed large, green, wrinkled. Per lb., $20 \mathrm{c}$; 2 lbs., $35 \mathrm{c}$, postpaid. $1 / 4$ bu., $\$ 1.75$; per bu.. $\$ 6.00$.

\section{DWARF GRAY SUGAR.}

The old variety of the edible-podded sort, and is used in no 0 ther way Grows about 2 feet high and is remarkable for its earliness. Pods are broad, flat and crooked and contain 5 to 6 peas. Seed is brown and wrinkled. Per lb., 20c; 2 lbs., 35c, postpaid.

\section{WHITE MARROWFAT.}

Vines hardy, strong, vigorous and bearing broad thick leathery pods near the top of the vine. Height 45 to 50 inches, foliage light green in color, pods 3 inches long. Ready to pick 69 days from planting. Sed large, smooth, white. Per lb., 20c; 2 lbs., 35c, postpaid. $1 / 4$ bu., $\$ 1.00$; per bu., $\$ 4.00$.

\section{BLACK EYED MARROWFAT.}

Strong and vigorous vines bearing pods near the top of the vine. Height 50 to 60 inches, light color foliage, pods 3 inches long. Ready to pick 69 days from planting. Seed large, smooth, white with a black eye. Per lb., $20 \mathrm{c}$; 2 ibs., $35 \mathrm{c}$, postpaid. $1 / 4 \mathrm{bu}$., $\$ 1.00$; per bu., $\$ 4.00$. 


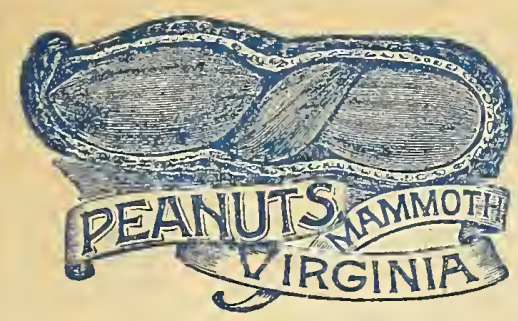

\section{PEANUTS}

Everyone Wants a Few for Winter.

Peanuts can be raised with but little expense, and are an exceedingly productive and paying crop. They are planted in much the same manier as potatoes, and require but little care beyond hilling up the young plants.

\section{SPANISH.}

This variety is smaller and sweeter than the common, or Virginia. Plants grow upright and strong, and are easily harvested.

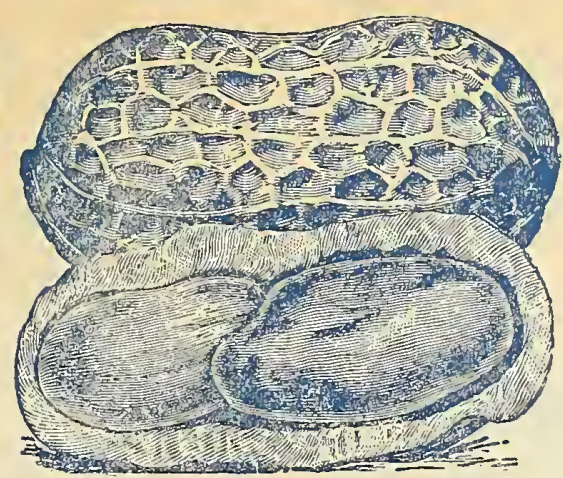

VHITE OR JUMBO.

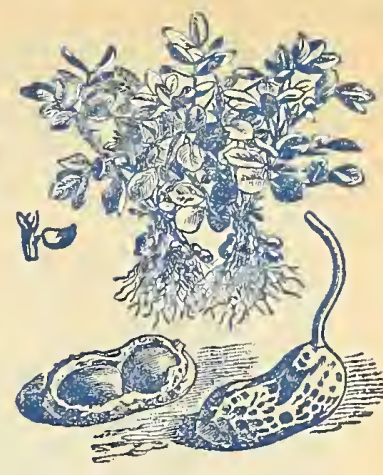

SPANISH.

VIRGINIA.

This is the common peanut grown in the South. WHITE, OF JUMBO PEANUTS.

Raised mostly for roasting; are not quite as hardy as the Spanish, but nuts are larger. Lb., $15 \mathrm{c}$ 2 lbs., $25 \mathrm{c}$, postpaid. Special prices on larger lots.

\section{PUMPKINS}

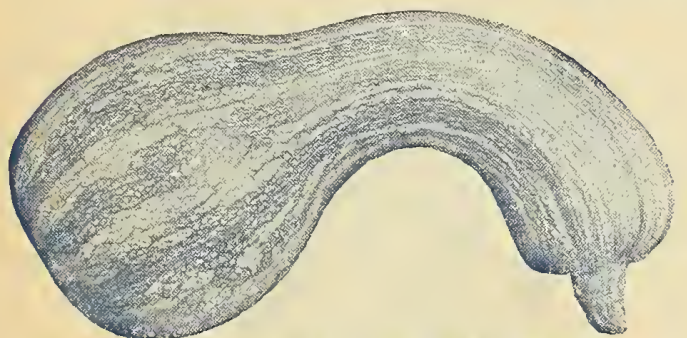

CASHAW STRIPED CROOKED NECK.

With mottled green bands, rich yellow meat, tender and sweet, equal to sweet potatoes when baked and nothing better for pies. Oz., $10 \mathrm{c} ; 1 / 4 \mathrm{db}, 20 \mathrm{c}$; ib., $60 \mathrm{c}$, postpaid.

\section{THANESGIVING PIE PUMPEINS.}

The finest and sweetest of all pumplins. I have been offering this variety for several years, and have found not one to equal it

They are not large, but just the proper size for easy handling and their quality is unsurpassed. If you like pumpkin pies, just plant some of this and you will be more than pleased. They are of an orange yellow and the flesh is fine grained. Pkt., 5c; 0z., 10c; $1 / 4$ lb., 20c.; lb., 60c, postpaid.

The old favorite pumpkin. Pkr., 5c; oz., 10c; $1 / 4$ lb., 20c; 1b., 60c, postpaid. WINTER IUXURX.

Very productive, fine grained, a golden russet

color and excellent keeper. Pkr., 5c; oz., 10c; 1/4 1b., $20 \mathrm{c} ; 1 / 21 \mathrm{~b} ., 55 \mathrm{c}$, postpaid.

Extensively used throughout New England and New York State for field culture, is generally planted in with corn. Pkr., 5c; oz., 10c; 1/4 lb., 15c; planted in with

KING OF THE MAMMO'THS.

This is also called the Jumbo, True Pot Iron, Mammoth Yellow. It is the largest pumpkin grown. averaging from 100 to 200 pounds. Flesh fine grained and has an orange-yellow skin. Pkt, $5 \mathrm{c}$. oz. grained and has an orange-yellow sk

\section{Kentucky Field Old Favorite Variety}

Oz., 10c; 1/2 1b., 20c; 1b., 40c. JAPANESE PIE.

Flesh thick, fine grained and sweet. Seed cavity small in one end, while the large neck is solid meat. Pkt., 5c; oz., 10c; 1/4 lb., 30c; lb., 50c, postpald. COMIMON FIELD.

The well known Conn. variety. Fine for stock feeding. Pkt., $5 \mathrm{c}$; oz., $10 \mathrm{c}$; $1 / 4$ lb., $15 \mathrm{c} ; 1 / 2 \mathrm{lb} .25 \mathrm{c}$; lb., $40 \mathrm{c}$, postpaid.

TENNESSEE SWEET POTATO.

Medium size and creamy white color: fine for cooking. Pkt., $5 \mathrm{c}$; oz, $10 \mathrm{c} ; 1 / \frac{1}{1 \mathrm{~b}} ., 25 \mathrm{c} ; 1 / 2 \mathrm{lb} ., 30 \mathrm{c}$ : lb., $50 \mathrm{c}$, postpaid.

MAMMOTH YELLOW POTIRON.

A very large, flat round, variety, much resembling King of the Mammoths in shape, size and color. Plet. $5 \mathrm{c} ; 0 \mathrm{z}, 10 \mathrm{c} ; 1 / 4$ lb., $15 \mathrm{c}$; 1b., $40 \mathrm{c}$, postpaid.

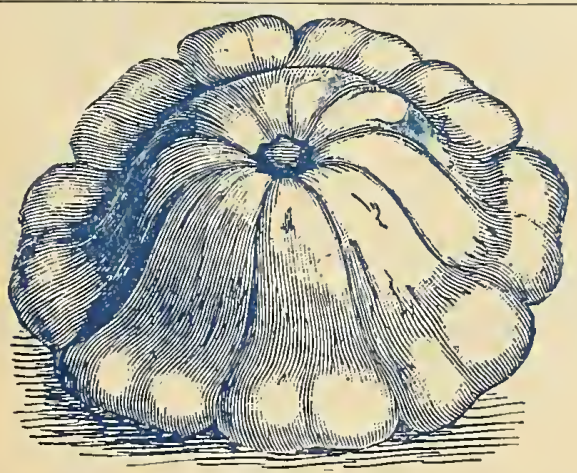

SUMMER SQUASH.

Pkt. Oz. 1/4 lb. $1 \mathrm{~b}$

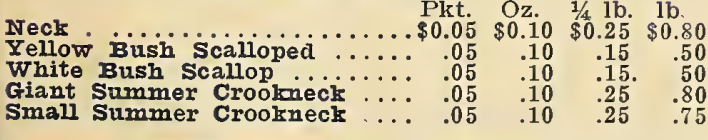

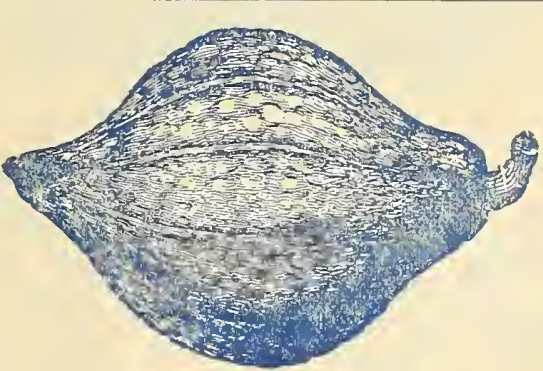

WINTER SQUASH.
Pkt. Oz, 1/4 lb, lb.

Improved Fubbard ........ \$0.05 \$0.10 \$0.25 \$0.80

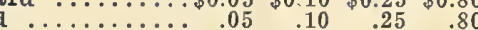
Golden

Improved IIarblehead............... 05 .05

NTammoth Chilli......... $.05 \quad .10 \quad .20 \quad .75$

Sibley............... $.05 \quad .10 \quad .20 \quad .75$ 


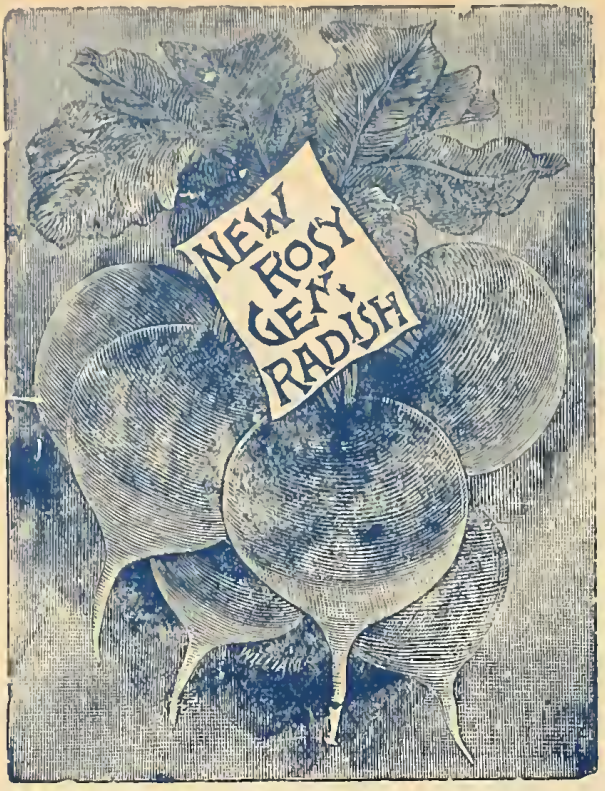

ROSEY GEM, EXTRA EARLY.

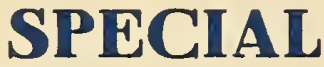

\section{Genuine French Grown Early Scarlet White-Tip Turnip Radish Seed, Per lb. Post Paid, $4 \mathrm{H} C$ Refunded.}

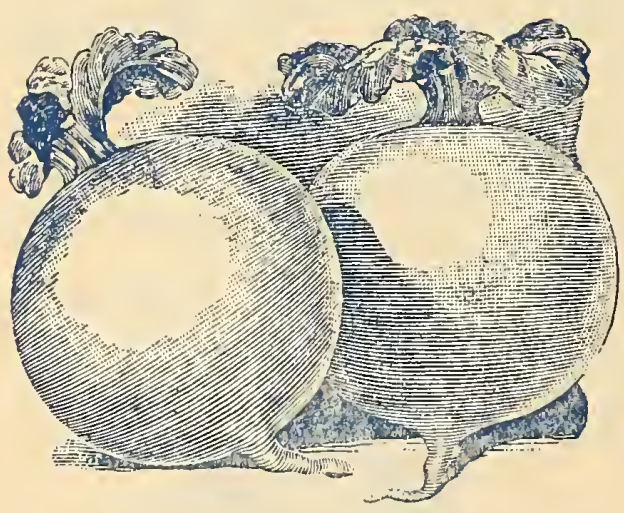

TURNIPS.

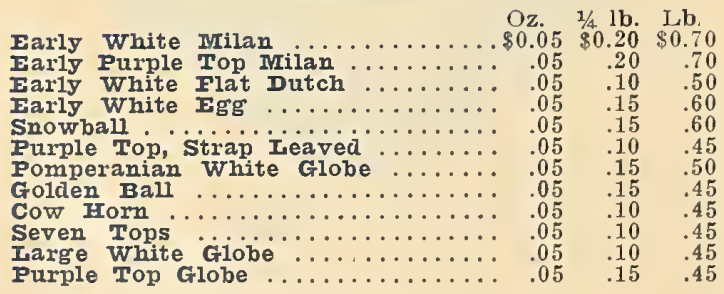

TOBACCO.

\section{IMPORTED RADISH SEED.}

Oz. $1 / 4 \mathrm{lb} . \mathrm{Lb}$.

Rosey Gem, extra early, round red,

white tip ................. \$0.05 $\$ 0.15 \$ 0.45$ Scarlet Turnip, extra early, round

red, white tip .................. .05 $.15 \quad .45$

Woods' Early Frame, extra early,

long scarlet type ............. .05 $.15 \quad 45$

Non-Plus-Ultra, early forcing round

red. . ................... $05-15-45$

Early Dark Red Turnip, forcing... $\quad .05 \quad .15 \quad .45$

Scarlet Globe, very dark red.....

Early White Turnip, pure white. $\quad 05-15 \quad 45$

White Olive Shape, short tops..... $\quad .05 \quad .15 \quad .45$

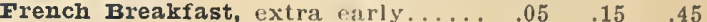

long Bright Scarlet, white tip.... $\quad .05 \quad .15 \quad .45$

Chartier, red, pink and white.....

Icicle, pure white, extra early..... $\quad .05 \quad .15 \quad .45$

Lady Finger, white, extra early... $\quad .05 \quad .15 \quad .45$

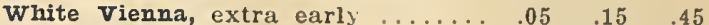

White Strassburg, very fine......

\section{WINTER VARIETIES.}

Oz. $\quad 1 / 6 \mathrm{lb} . \quad$ Lb.

Round Ieaved .............\$0.05 \$0.20 \$0.65

Bloomdale Savod Leaved $\ldots \ldots \ldots \ldots .05 \quad .20 \quad .65$

Iong Standing ................... .05 $.20 \quad .65$

$\begin{array}{lllll}\text { Prickly Winter } \ldots \ldots \ldots \ldots \ldots \ldots \ldots & .05 & .20 & .65\end{array}$

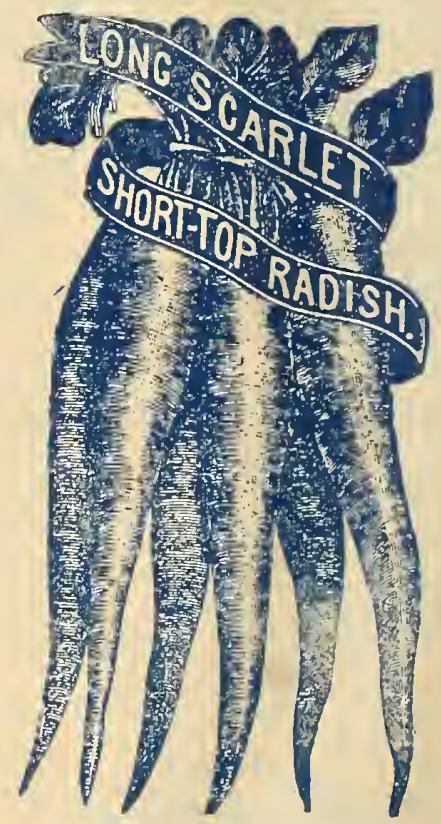

SPINACH.

Oz. 1/4 lb. Lb

Round Ieaved ...............\$0.05 \$0.20 \$0.65 Bloomdale Savoy Leaved $\ldots \ldots \ldots \ldots, .05 \quad .20 \quad .65$

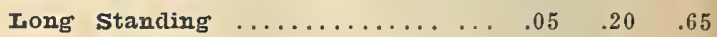
Prickly winter $\ldots \ldots \ldots \ldots \ldots \ldots \ldots, .05 \quad .20 \quad .65$

\section{SAGE.}

Oz. $1 / 4 \mathrm{lb}, \mathrm{Lb}$.

Holt's Mammoth

$\$ 0.10 \quad \$ 0.25 \quad \$ 0.75$

SALSIFY. 


\section{Hayes' Mammoth Ponderosa The Largest of Tomatoes}

We have no hesitancy in saying this is the largest Tomato now grown. It is a handsome red variety, very productive, ripens in July and continues bearing till frosts. Pkt., $5 \mathrm{c} ; 0 \mathrm{z}$., $20 \mathrm{c} ; 1 / 41 \mathrm{~b} ., 75 \mathrm{c} ; 11 \mathrm{~b} ., \$ 3.00$, postpaid.

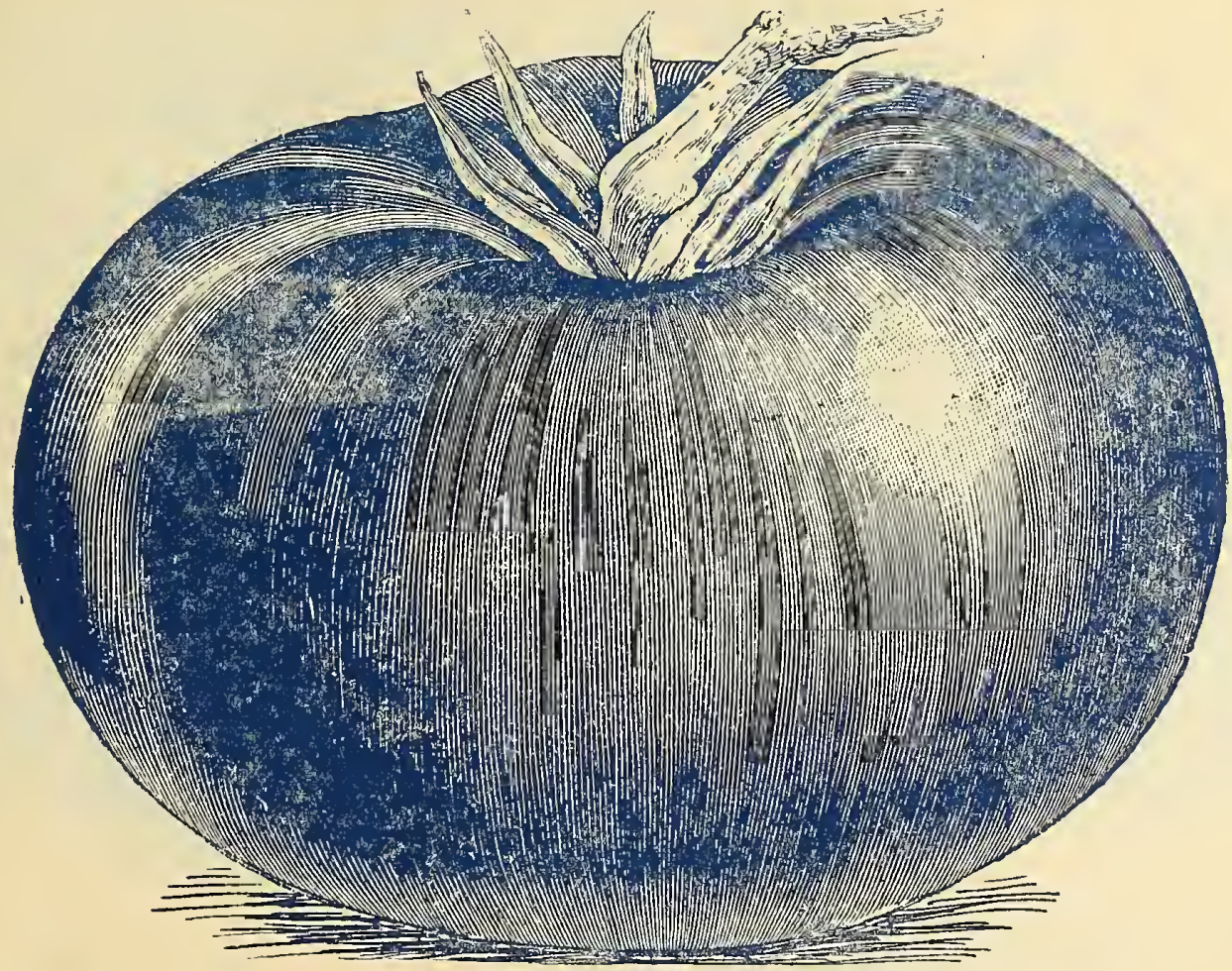

HAYES' MAMMOTH PONDEROSA.

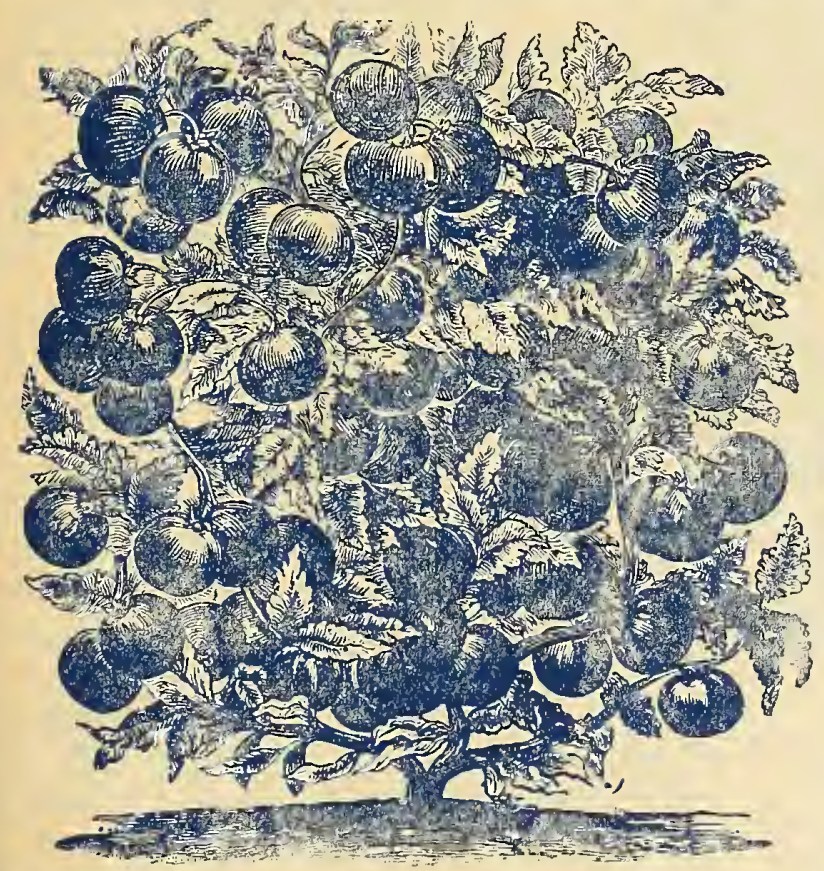

KANSAS STANDARD TOMATO.

One of the best Tree Tomatoes grown. Pkt., 5c; oz., $20 \mathrm{c} ; 1 / 41 \mathrm{~b}$., $75 \mathrm{c} ; 1$ lb., $\$ 2.50$.

\section{TOMATOES OF FAVORITE VARIETIES}

\section{DWARF STONE.}

New. As early and nearly double the size of Dwarf Champion, much more productive. Pkt., $5 \mathrm{c} ;$ oz., $20 \mathrm{c} ; 1 / \mathrm{1} / \mathrm{b}$., $75 \mathrm{c} ; 1 \mathrm{~b}$., $\$ 2.00$.

\section{DWARF CHAMPION.}

Distinct in foliage and habits of growth, being compact and upright; fruit smooth, early purplish red. Pkt., 50c; oz., 20c; 1/4 ib., 60c; $1 \mathrm{~b}$.,
$\$ 2.00$.

\section{CHALK'S JEWEL.}

New. Very early, productive; smooth, round and of superior qualilty. Pkt., 5c; oz., 20c; $1 / 41 \mathrm{~b}$., $60 \mathrm{c} ; 1 \mathrm{~b}$., $\$ 2.00$.

Reneral favorite with canners. Vine vigorou productive. Fruit round, very large, very der: red in color and astonishingly heavy. Pkt., $5 \mathrm{c} ;$ oz., $15 \mathrm{c} ; 1 / 41 \mathrm{~b} ., 50 \mathrm{c} ; 1 \mathrm{~b}, \$ 1.75$.

\section{MATCHLESS.} Very large, smooth, solid and fine flavored;
cardinal red. Pkt., 5c; oz., 15c; $1 / 4$ lb., 50c; 1b., $\$ 1.75$.

\section{BEAUTY} Livingston's. Large, smooth, pinkish red;
thick flesh. Plkt., 5c; oz., 15c; $1 / 2$ lb., 50c; $1 \mathrm{~b}$., \$1.75. RED ROCK.

Fine large red variety for canners and truckers. Pkt., 5c; oz., 15c; 1/4 lb., 50c; 1b., $\$ 1.75$. JUNE PINK.

New. Very early, of medium size, round, smooth and very solid, color pink. Pkt., 5c; oz. $15 \mathrm{c} ; 1 / 41 \mathrm{~b} ., 50 \mathrm{c} ; 1 \mathrm{~b} ., \$ 1.75$

\section{GOLDEN QUEEN}

Yellow, ripens early, is large sized, smooth and solid; excellent quality. Pkt., 5c; oz.. 15c $1 / 4$ 1b., 50c; $1 \mathrm{~b}$., $\$ 1.75$. 


\section{Tomatoes}

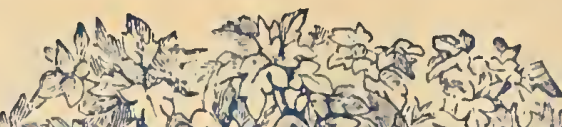

SPARKS EARLIANA

No. 10 Extra Early

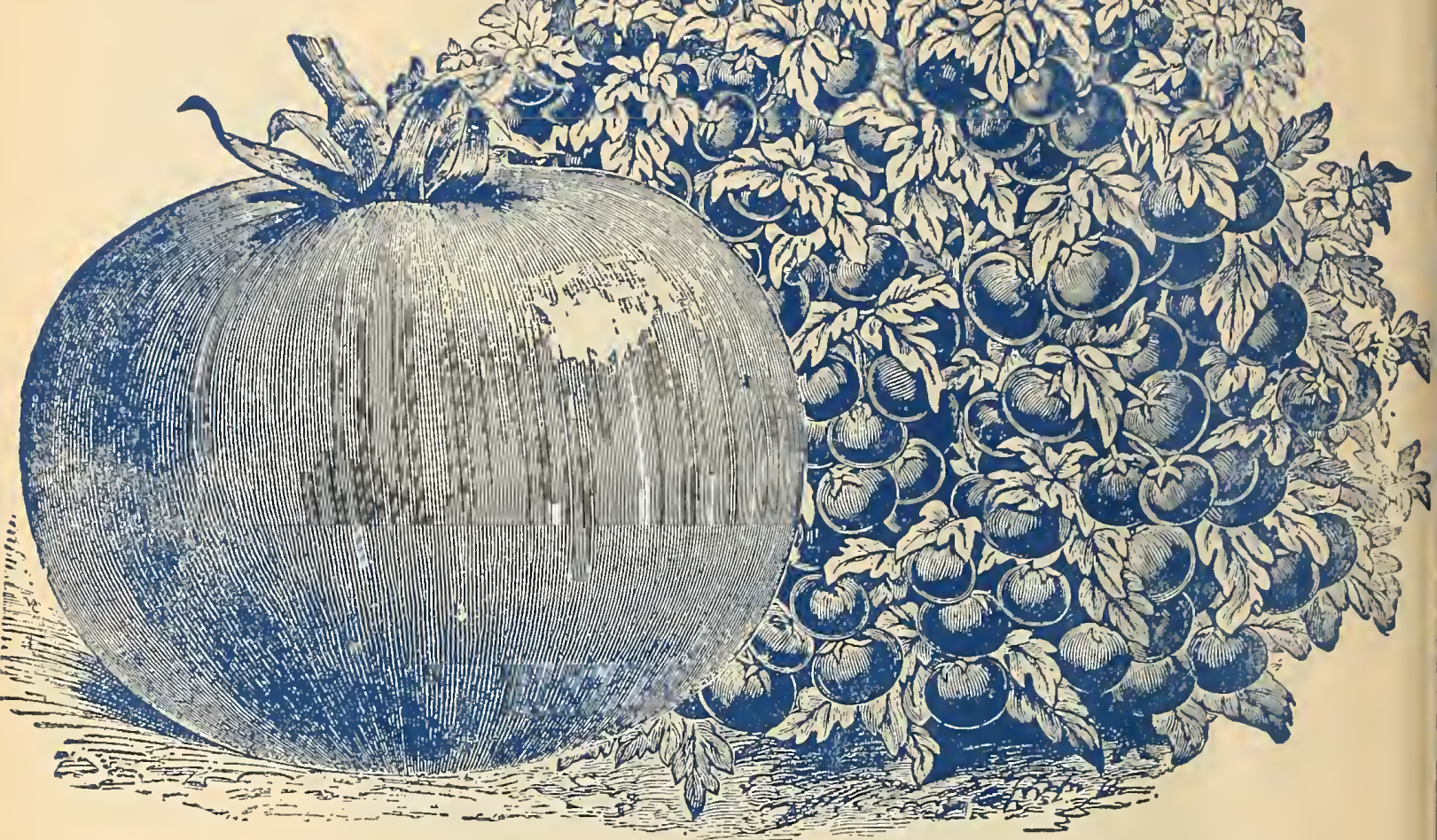

This variety is truly an Early wonder and stands without a rival in the early field. It is the money maker for the market gardener. Our seed of this Tomato is the Genuine true to name and produces Iarge, Smooth Tomatoes. Grown for us in New Jersey, and is known as Spark's Earliana, No. 10. Per pkt., 10c; $1 / 4$ Ib., 75c; 1 Ib., $\$ 2.50$, postpald.

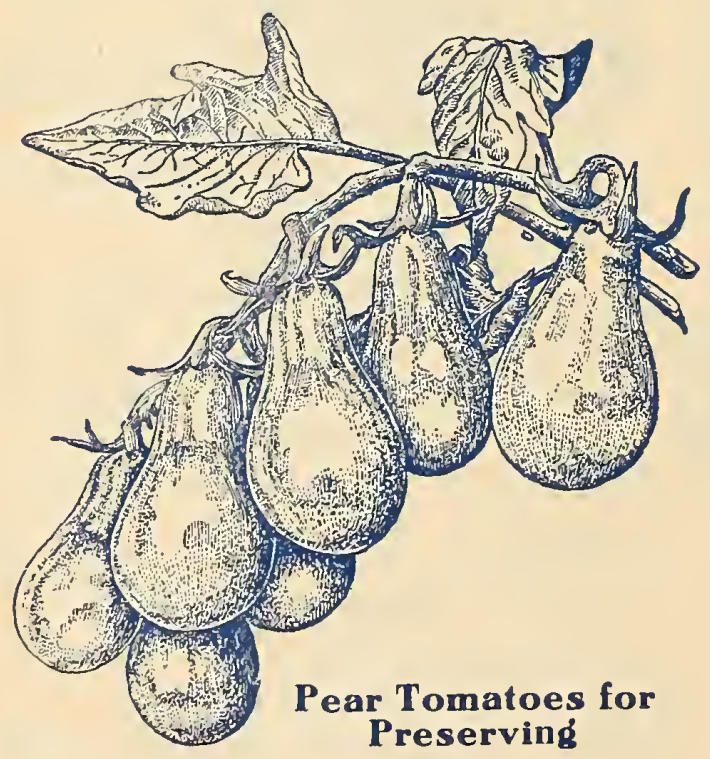

\section{SMALL FRUITED TOMATOES}
These are very delicious for preserving. The vines are immensely productive.

\section{RED PEAR-SHAPED.}
This is a leading favorite for preserves and also to make "tomato figs." The fruit is bright. of true pear shape, and of rich distinct flavor. $\mathrm{Oz}$., $15 \mathrm{c} ; 1 / 4 \mathrm{~b}$., $60 \mathrm{c} ; 1 \mathrm{~b}$., $\$ 2.00$.

\section{YELLOW PEAR.}
Similar to the Yellow Plum but the fruits have a slim neck or distinct pear shape. Oz., $15 \mathrm{c} ; 1 / 4 \mathrm{lb}$., $60 \mathrm{c} ; 1 \mathrm{~b} ., \$ 2.00$.

\section{YELLOW CHERRY.}
The small yellow fruits, borne in clusters average half an inch in diameter. Per pkt., $5 \mathrm{c}$; oz. $15 \mathrm{c}$ $1 / 4$ ib $500^{\circ}$ ib, 175 .

\section{RED CHERRY}

Little fruits of a bright scarlet color. Per pkt., $5 \mathrm{c}$; Oz., 15c; $1 / 4$ 1b., $50 \mathrm{c}$; $1 \mathrm{~b} ., \$ 1.75$.

STRAWBERRY, OR HUSK TOMATO.

Plants of low-spreading growth and immensely productive. The small yellow fruits are each enclosed in a husk. Of very sweet flavor, highly esteemed for preserving or making pies. They are also excellent to eat raw as fruit. Oz., $15 \mathrm{c} ; 1 / 41 \mathrm{~b}$., $50 \mathrm{c} ; 1 \mathrm{~b} ., \$ 2.00$.

Our Tomato seed is grown for us by the most reliable growers in the world; true to name and sure to grow. Iet us prove it to you this year. 




\section{Bonny Best Tomato}

For a really good extra early tomato, this new prolific variety is a wonder and the market gardeners or shippers who plant it are bound to get top prices of the earliest market. It's a wonder for extra earlincss, smoothness and heavy bearing; immenscly prolific, combined with vigorous growing qualities. Begins to "set" fruit from the first blooms, and as the foliage is rather light and open it lets the sun in to color and ripen the fruit quickly. Our illustration from a photograph shows about one-third its size and its extremely heavy bearing qualities. Begins with the earliest and keeps right along bearing. Fruits are from $2 \frac{1}{2}$ to 3 inches in diameter. Its color is an intense glowing scarlet, and ripens evenly. A splendid shipper and of very fine eating quality for home garden use. Its emoothness of skin and regularity are excepticnal for an extra early variety. If you are a truck grower you cannot afford to miss plainting it; if you are a home gardener you need it for earliest use. We have seen as many as 34 good sized, smooth, ripe tomatoes on a single plant at one time. Immensely proIfic and beyond question the most desirable extla early tomato offered for sale. It represents years of closest and most careful work in seed sclection and plant breeding. Plit., 10c; $1 / 2$ oz., 20c; oz., 35c; 1/4 lb., \$1.00; 1b., \$3.50, postpaid.

\section{John Baer}

\section{Tomato}

One of the earliest and best Tomatoes now produced. This Tomato is well adapted to main crop planting. It matures so quickly that it ranks first in the market gardener's field for early marliet purposes. The form is perfect, uniform, large and attractive. The flesh is very firm. A robust grower, with short joints setting its clusters closer together than most varieties of early tomatoes. Our illustration shows one branch of clusters. which hang profusely over the vines. They are a brilliant deep red color, no core'.almost free from seed and very fine flavored. Fruit ripens evenly, and is a good shipper. Our seed is produced by one of the largest seed growers in the world, and is true to name and type. Price, pkt., 5c; oz., 35c; 1/4 1b., $\$ 1.25$; lb., $\$ 5.00$.

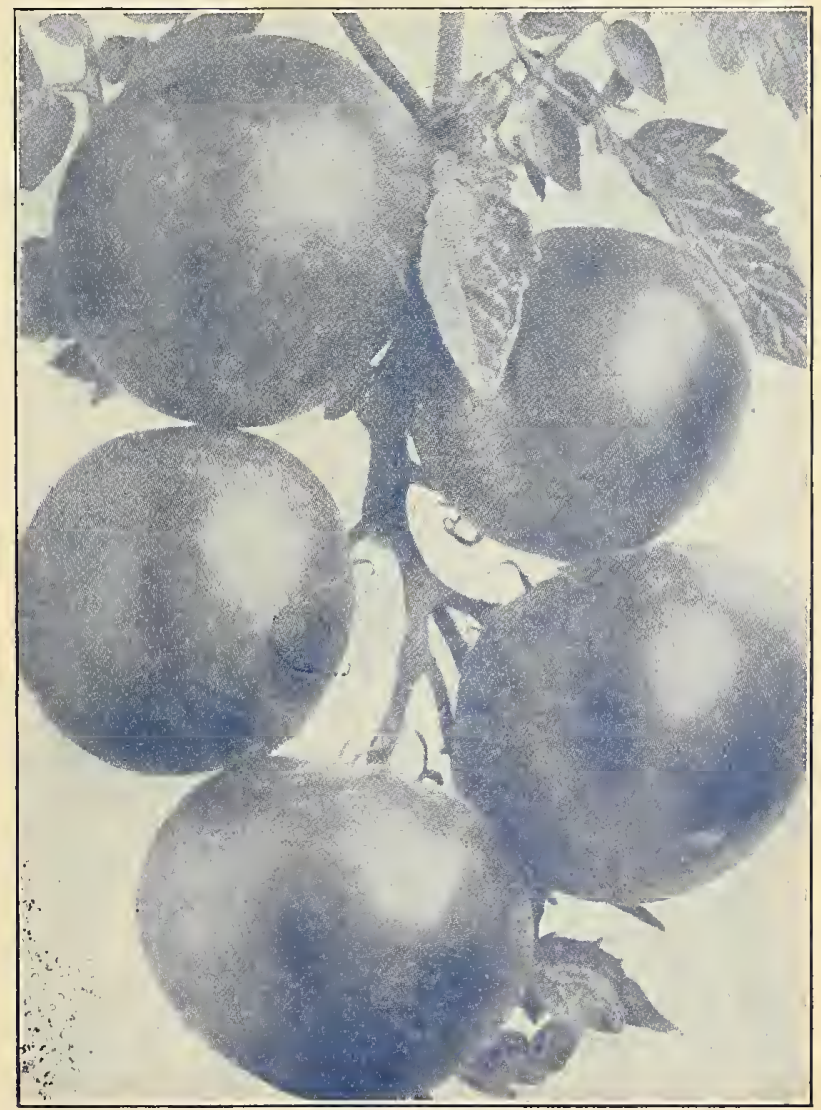




\section{Poultry Department}

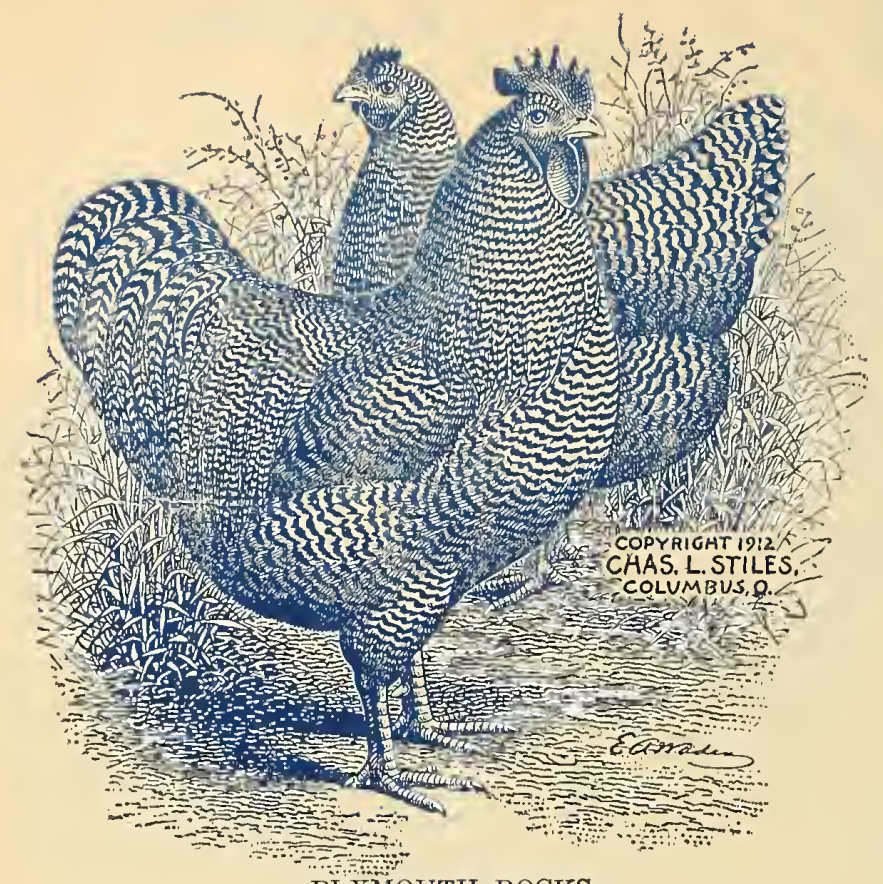

PLYMOUTH ROCKS.
We wish to say that we have many customers who are Breeders of High Class FANCY POULTRY. and we are offering you some of the Best Bargains in Eggs for Early Hatching. We also offer you the Stock of these varleties herein quoted. If in the market for anything in Poultry and Eggs, write us. Our stock that we have listed are from PRIZE WINNING BIRDS. Our stock will be shipped direct from the breeders. We guarantee $12 \mathrm{eggs}$ out of 15 to Ilatch, or will replace the setting at half price. We offer you as follows. Let us know what you want.

BARRED PLYMOUTH ROCKS.

This variety is a general favorite among all breeders.

\section{WHITE ROCKS.}

The grandest pure white variety now bred. BUFF ROCKS.

Now becoming one of the greatest favorites.

\section{PARTRIDGE ROCKS.}

This is a splendid new colored variety of fine qualities.

Prices: 15 eggs, from prize winning pens, $\$ 2.50$ per setting; price on the BIRDS a matter of correspondence as to what you want- $\$ 2.00$ to $\$ 5.00$ each.

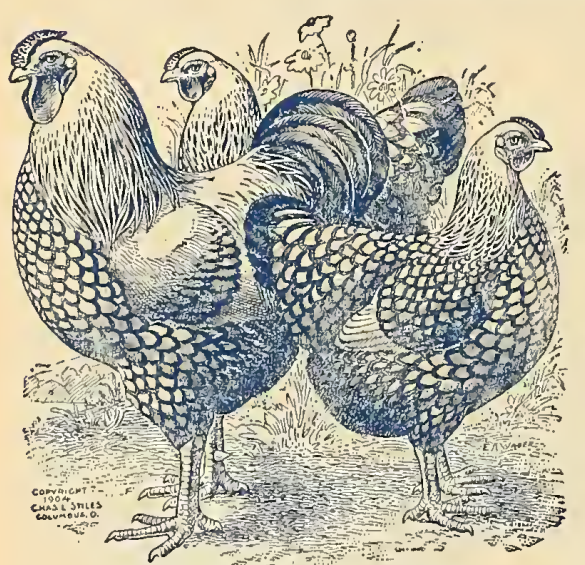

SILVER WYANDOTTES.

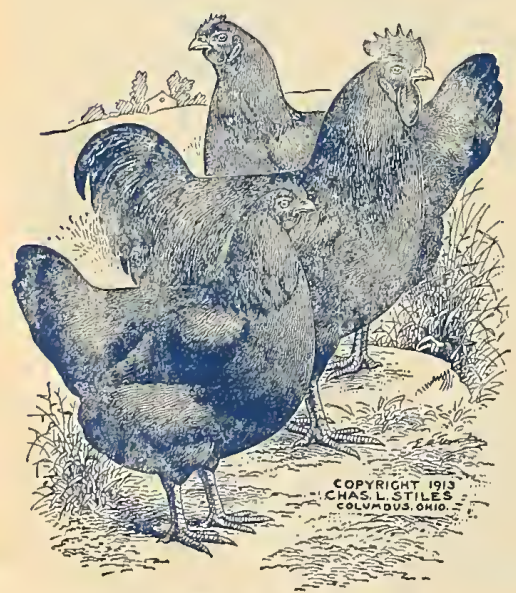

RHODE ISLANND REDS.

\section{WYANDOTTES.}

The Wyandotte Family is gen'srally recognized as among the best American breeds.

White Wyandottes, a most beautiful pure white bird, strong and vigorous.

Partridge Wyandottes of fine plumage and color, good layers and early maturing.

Silver Spangled Wyandottes, the most popular birds of this breed.

Golden Wyandottes, the beauties of them all.

Price of 15 eggs, $\$ 2.50$; special prices on larger lots. Prices of birds from $\$ 2.00$ u p to $\$ 5.00$.

\section{RHODE ISLAND REDS.}

Single and Rose Comb. Eggs per setting of. $15, \$ 2.50$.

\section{BLACK LANGSHANS.}

Eggs per setting of $15, \$ 2.50$.

\section{IIGHT BRAHMAS.}

Eggs per setting of $15, \$ 2.50$. BUFF COCHINS.

Eggs per setting of $15, \$ 2.50$.

BUFF ORPINGTONS.

Eggs per setting of $15, \$ 2.50$. WHITE ORPINGTONS.

Eggs per setting of $15, \$ 2.50$.

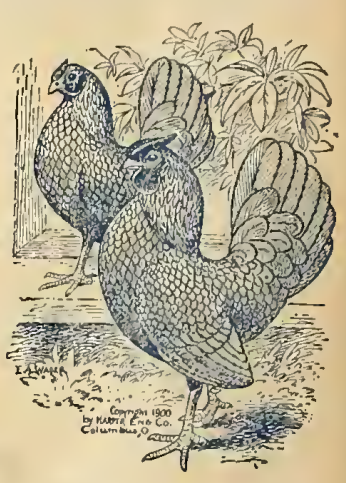

GOLDEN SEBRIGH'T.

\section{BANTAMS}

Buff Cochin.

Black Cochir.

White Cochin.

Partridge Cochin.

Black Japanese.

White Polish.

Red Pyle Game.

Brown Red Came.

Birchen Game.

Rose Comb Black.

White Japanese.

Black Tailed Japanese.

Eggs per setting of 15 , $\$ 2.50$. 


\section{Ornamental Poultry}

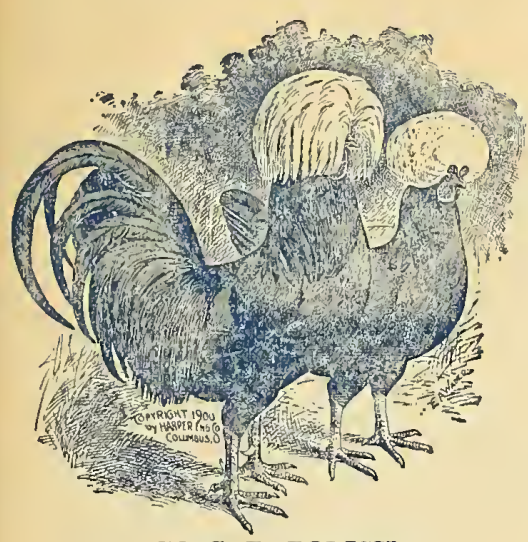

W. C. B. POLISH.

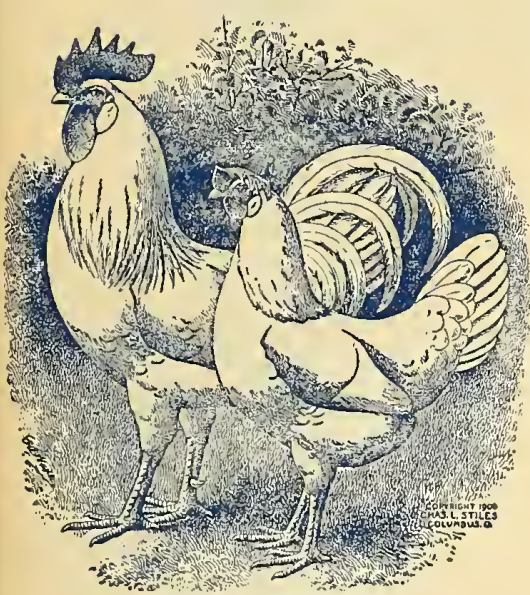

WHITE LEGHORN

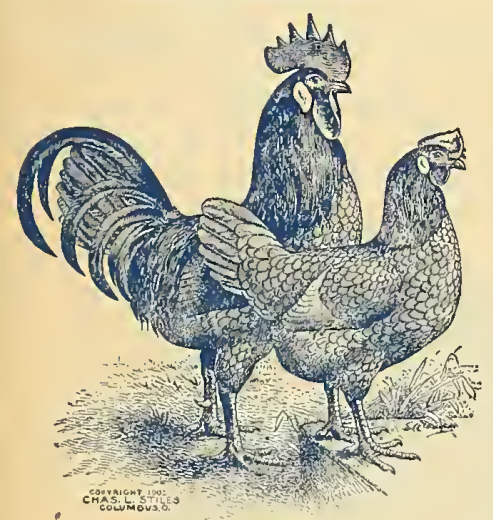

BROWN LEGHORN.

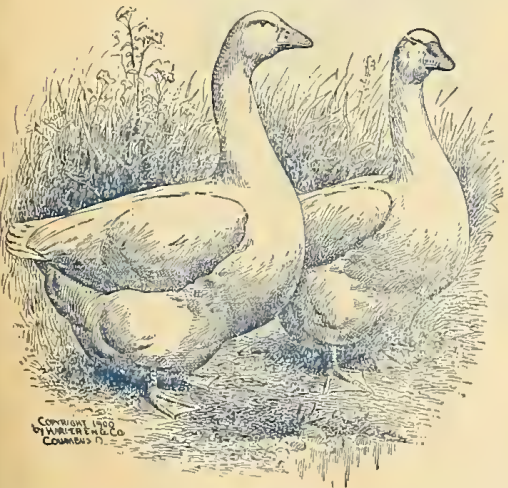

WHITE EMDEN.

\section{WHITE CRESTED BLACK POLISH.}

This is my own breeding and birds can be seen at our place of business. Eggs per setting of $15, \$ 3.00$. Birds from $\$ 3.00$ to $\$ 10.00$ each.

White Polish, Bearded White Polish, Golden Polish, Bearded Golden Polish. Silver Polish, Laced Polish, Golden and Silver Spangled Polish. Eggs per setting of $15, \$ 3.00$.

\section{HOUDANS.}

Bearded. Eggs per $15, \$ 3.00$. JAPANESE SILKIES.

White. Eggs per 15, $\$ 3.00$.

\section{LEGHORNS.}

S. C. Brown Leghorns. Eggs per setting of $15, \$ 2.50$.

R. C. Brown Leghorns. Eggs per setting of $15, \$ 2.50$

S. C. White Leghorns. Eggs per setting of $15 . \$ 2.50$.

R. C. White Leghorns. Eggs S. C. Buff Teghorns. Eggs per setting of $15, \$ 2.50$.

R. C. Buff Leghorns. Eggs per setting of $15, \$ 2.50$.

\section{BLUE ANDALUSIANS.}

Eggs per setting of $15, \$ 2.50$.

MOTTLED ANCONAS.

Rose Comb and Single Comb. Eggs per setting of $15, \$ 2.50$.

\section{WHITE FACED BLACK SPANISH.}

Eggs per setting of $15, \$ 2.50$. SILVER SPANGLED HAMBURGS.

Eggs per setting of $15, \$ 2.50$

\section{GOLDEN SPANGLED} HAMBURGS.

Eggs per setting of $15, \$ 2.50$. MINORCAS, BLACK.

Eggs per setting of $15, \$ 2.50$

\section{GAMES.}

Dark Cornish, Black Breasted, Red Game, Golden Duck Wing and Red Pile. Eggs per setting of $15, \$ 2.50$

\section{DUCKS.}

Price on Duck Eggs are $\$ 2.50$ for 11 eggs. We guarantee a hatch of three-fourths or will make second setting half price. We kquote white Pekin Rouen. White Call, Bast India, Colored and White Muscovy. Buff Crested, White and Fawn Runner.

\section{GEESE}

Seven eggs make a setting. We guarantee 5 or will replace the setting at half price. Toulouse Geese Emden Geese. Eggs per setting $\$ 2.50$.

PEARL GUINEAS.

Eggs per 15, \$1.75. White, $\$ 2.50$.

The prices of the above birds a matter of correspondence. Let me know your wants. We guarantee every bird we send out or you can return it at our expense.
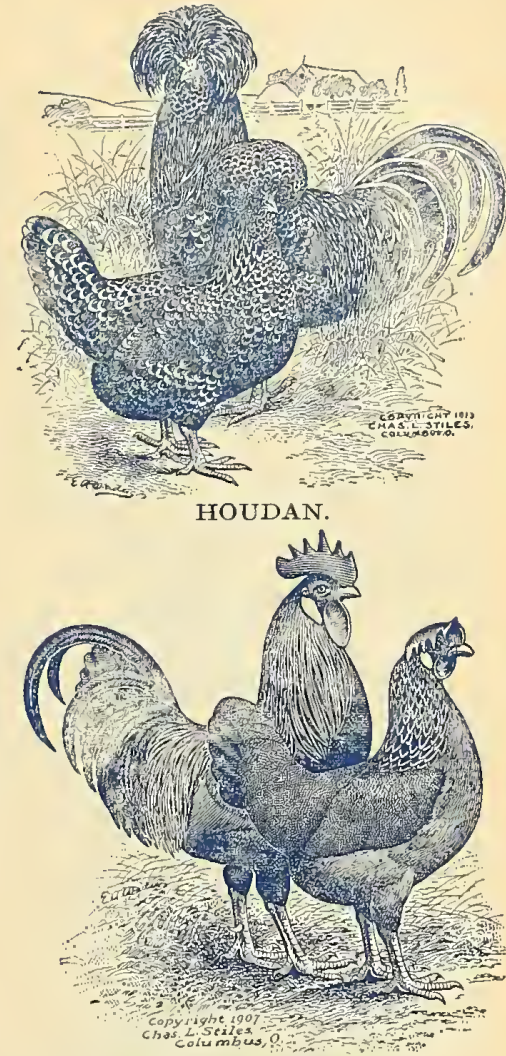

BLUE ANDALUSIAN.

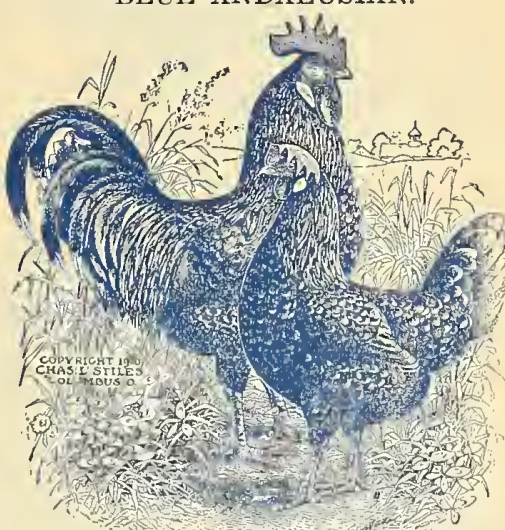

MOTTLED CONCORD.

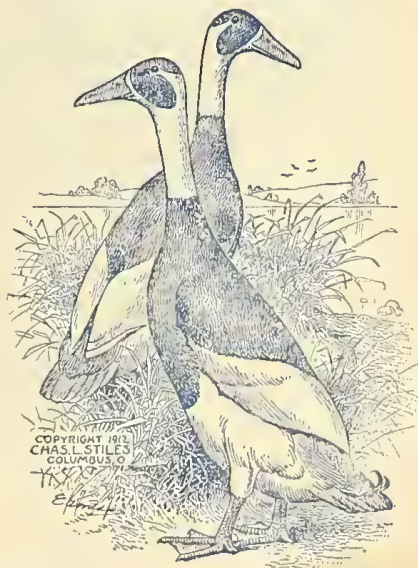




\section{Flower Seeds of Highest Quality}

5 LARGE PACKAGES FOR 10 CENTS

Guaranteed 10 Grow or Money Refunded.

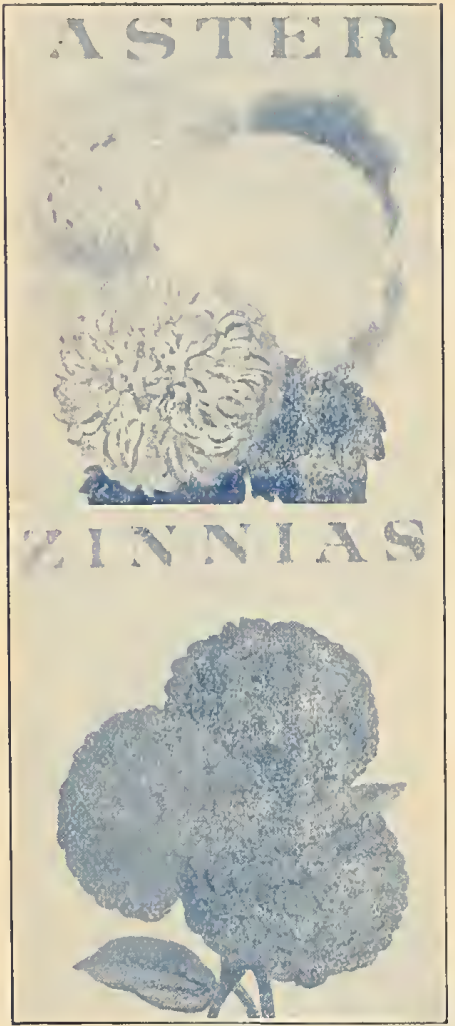

GAILLARDIA.

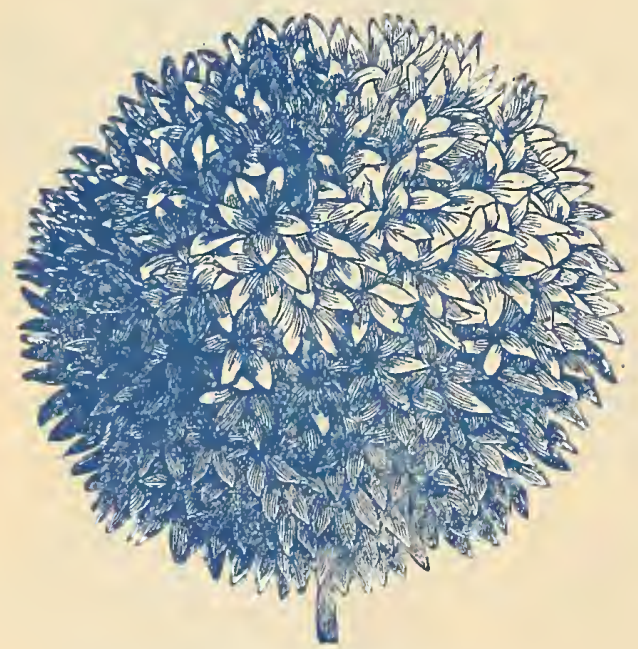

GAILLARDIA.

Mixed. HOLLYHOCK.

Mixed. DOLICHOS (HYACINTH BEAN).

Mixed. DOUBLE DAISY.

Mixed. DIANTHUS (OR PINKS).

Mixed. DIGITALIS (FOX GLOVE).

Mixed.
ALL FLOWER SEEDS 2 Pkts. 5 cents 5 Pkts. 10 cents

$5 \mathrm{c} ; 3$ for $10 \mathrm{c}$. AGERATUM (FLOSS FLOWER)

Pink, White, Blue and Mixed ALXSSUM, SWEET.

White

AMARANTHUS.

Variagated foliage

ANTIRRHINUM (SNAP DRAGON)

White, Scarlet, etc.

Mixed, BALLOON VINE.

BELLIS PERENNIS (DOUBLE DAISY).

CANART BIRD FLOWER.

Yellow.

CASTOR BEANS (RICINUS).

Large, Purple and Bronze Foliage. CALLIOPSIS.

CALENDULA.

CANDY TUFF (IBERIS).

Mixed. Mixed

CLEMO (SPIDER PLANT). COLUMBINE.

Mixed. CARNATION

Marguerite. COBAEA. COBAEA.

Mixed. CHR YSANTHEMUM.

Mixed. CANA SEED.

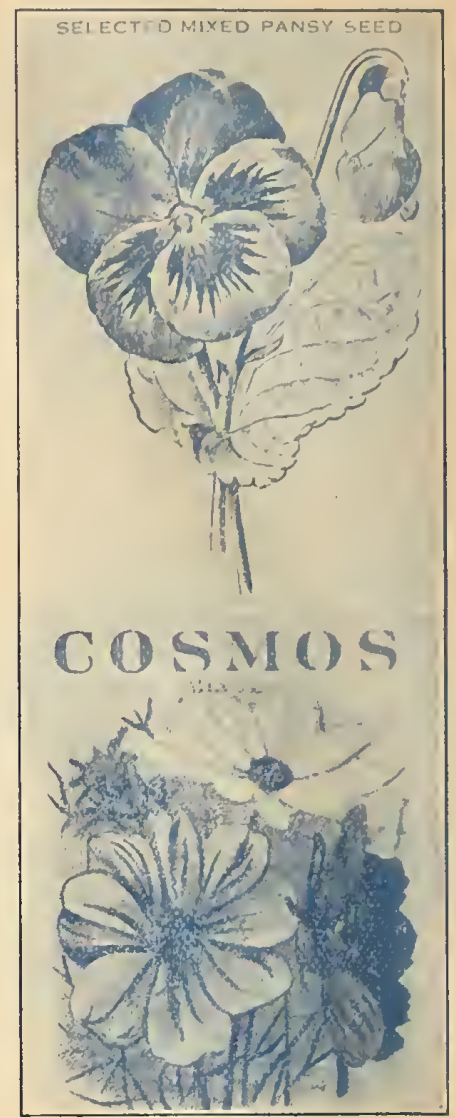

Mixed.

ESCHSCHOLTZIA (CALIFORNIA POPPY). Mixed.

FORGET-ME-NOT.

Mixed.

FOUR O'CLOCK (MARVEL OF PERU). Mired.

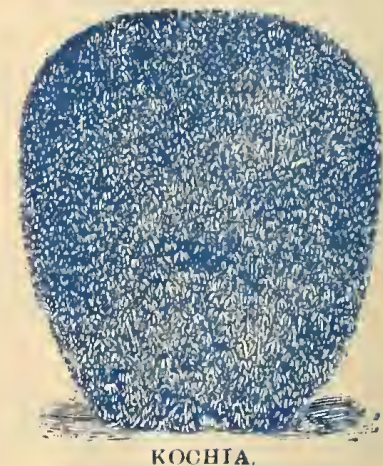

BURNING BUSH OR KOCHIA.

Mixed.

Mixed.

Mixed.

Mixed.

Mixed.

Mixed.
LARKSPUR (DELPHINUM).

LOBELIA.

LOVE-IN-THE-MIST.

MIGNONETTE.

MORNING GLORY (LARGE). 


\section{Flower Seeds=-.Continued}

PRICE ON All FloWer SEED, 2 Pkts. 5 cts., 5 Plits. 10 cts.

MARIGOLD.

Mixed.

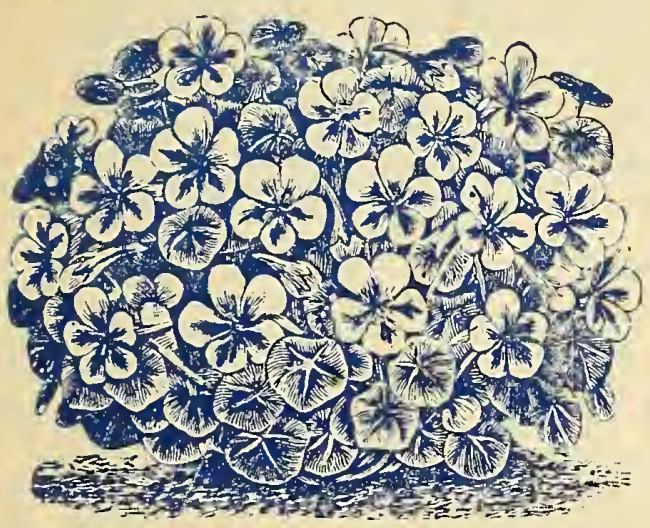

NASTURTIUMS.

Common Mixed. Fancy

\section{POPPIES.}

We have all kinds and colors.

Single and Double.

PETUNIAS.

Burbanks.

$$
\text { RAINBOW CORN. }
$$

MINIATURE SUNFLOWER.

\section{PYRETHRUM.}

Mixed.

SAIVIA (FLOWERING SAGE).

MAMMOTH RUSSIAN SUNFLOWER.

SCABIOSA (MORNING BRIDE).

Tall and Dwarf.

SWEET WILLIAMS.

Single and Double.

Mixed.

Mixed.

Mixed.

STOCKS

VERBENA.

WALLFLOWER.

WILD CUCUMBER.

Mixed, all kinds. ZINNIAS.

Shrubs and Bulbs in quantities at reduced prices. wite us.

\section{PORTULACR. (Moss)}

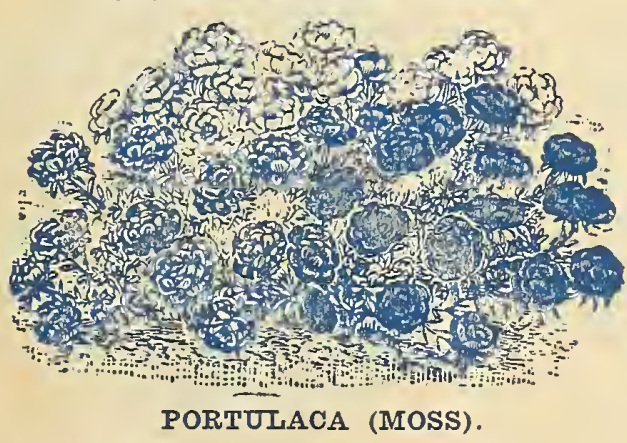

Single Mixed.
Double Mixed.

\section{S W E E T P E A S}

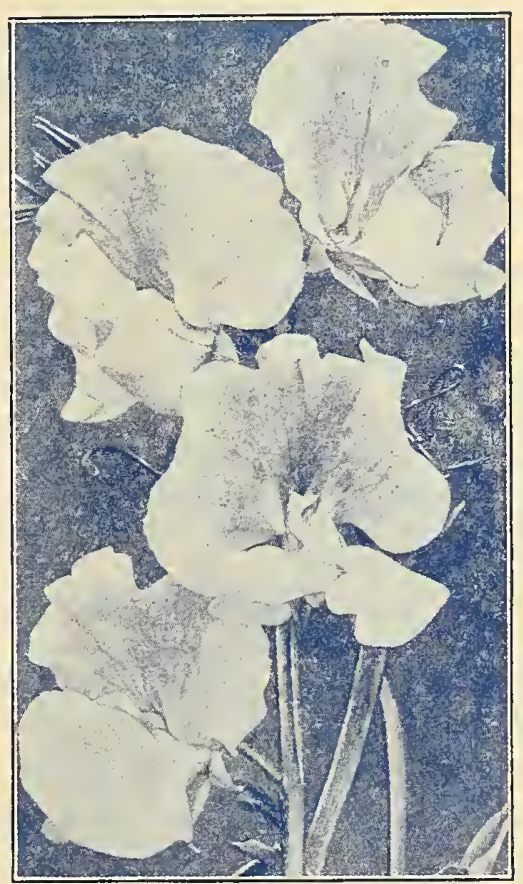

Sweet Peas. In our collection we can give you many colors and varities. Mixed varieties, 2 pkts. $5 \mathrm{c}$; 5 pkts., $10 \mathrm{c}$; per oz., $10 \mathrm{c}$; per lb., postpaid, $75 \mathrm{c}$.

\section{GRADNIFLORA TYPES.}

Blanch Ferry (pink and white), Evelyn Byatt (fine orange salmon), Janet Scott (fine pink), Lottie Eckford (white suffused lavender), Prince of Wales (bright rose), Queen Alexander (bright scarlet), Sadie Burpee (large pure white). Price per oz., $15 \mathrm{c}$; per $1 \mathrm{~b}$., $\$ 1.00$, postpaid.

\section{PHLOX.}

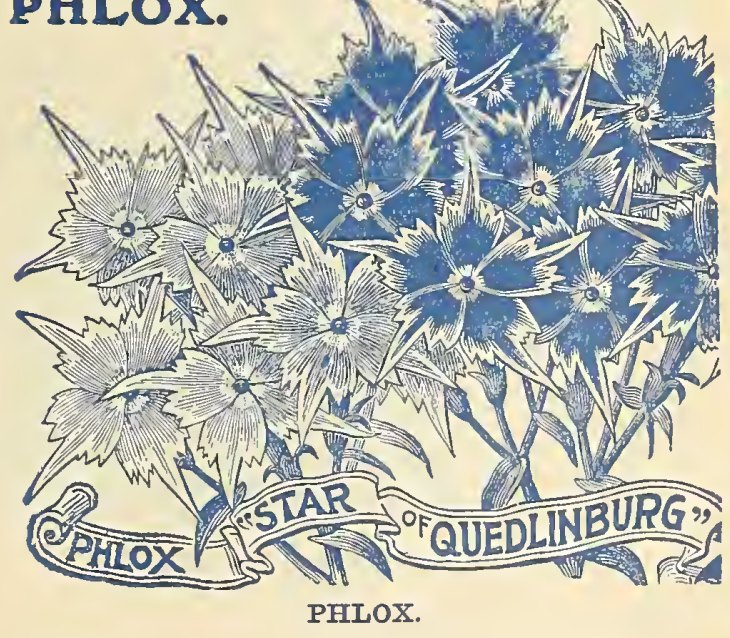

Mixed. 


\section{Flowers, Bulbs and Shrubs}

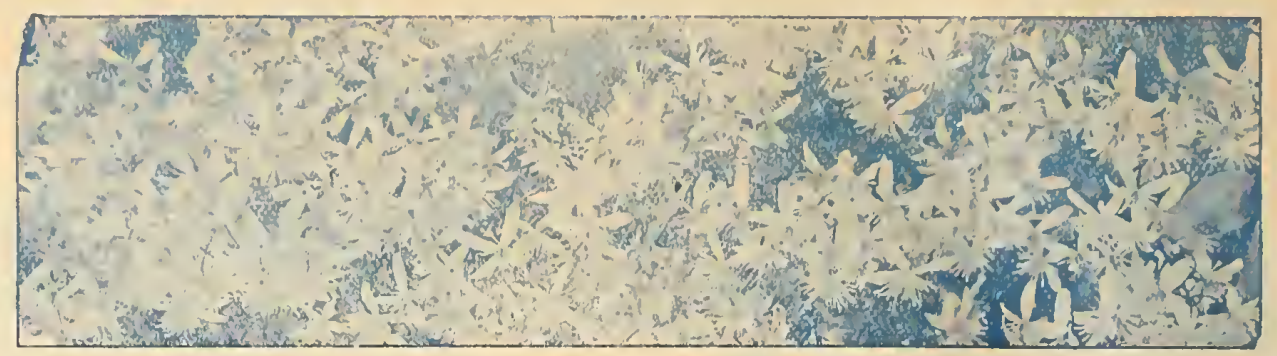

\section{CLEMATIS PANIGULATA}

Duchess of Edinburg. One of the best double whites, of vigorous habit, very free of bloom and deliciously fragrant.

Fenryil. A vigorous grower and a free bloomer, producing its large, pure white flowers constantly during summer and early autumn.

Jackmanil. The flowers are large, intense rich velvety violet-purple and are produced in such masses as to form a cloud of bloom. Well-known and very popular.

Madame Baron Veillard. Of recent introduction and quite like its parent, the popular Jackmanii, in habit and makeup, except that its flowers are a lively. satiny lavender-pink; entirely distinct from any other variety and charming in effect.

Madame Edonard Andre. Also of the Jackmanil type and is the nearest approach to a bright red that has yet appeared. The flowers are very large.

Ramona. Lavender-blue, flowers large, often nine inches across. Most beautiful of its color known. Price $15 \mathrm{c}$ each or three for $35 \mathrm{c}$.

\section{CINNAMON VINE.}

A charming climber with heart-shaped leaves and cinnamon scented flowers, making a perfect bower of beauty. It thrives anywhere, and when once planted will grow for years. They are grown from roots or tubers, and will grow in any locality. for 5c; per doz., $30 \mathrm{c}$, postpaid.

\section{MADERIA VINE (CLIMBING MIGNONETTE).}

A tuberous-rooted, rapid-growing climber which quickly covers a large space. Nothing better to train around the windows of a dwelling or to screen a porch or veranda. Fleshy, heartshaped leaves and pendant stems of fragrant flowers. 2 for $5 \mathrm{c}$ doz., $30 \mathrm{c}$, postpaid.

\section{TUBEROSE.}

Probably the most popular of all the summer-blooming bulbs on account of its fragrant, beautiful flowers. 5c each. 3 for 10c; doz., 50c, postpaid.

\section{SHRUBS.}

Snow Ball. Common ......................each $20 \mathrm{c}$

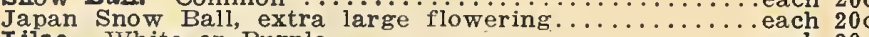

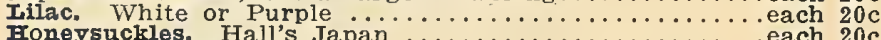
Foneysuckles. Hall's Japan $\ldots \ldots \ldots \ldots \ldots \ldots \ldots \ldots \ldots$ each $20 \mathrm{c}$

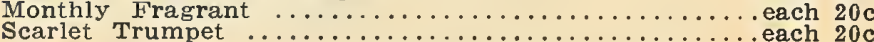

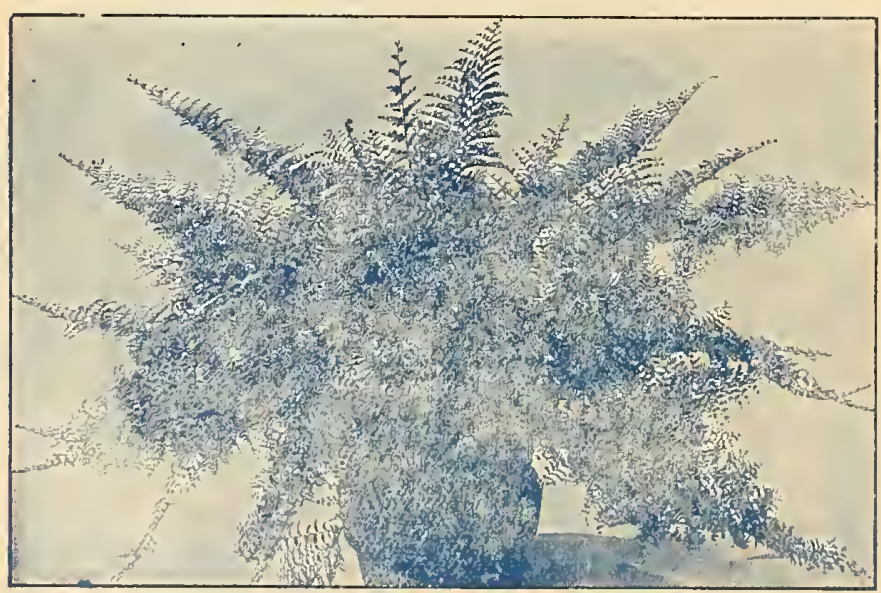

OSTRICH PLUME FERN.

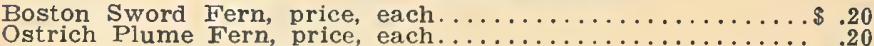

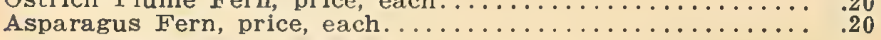
Three for $50 \mathrm{c}$, postpaid.

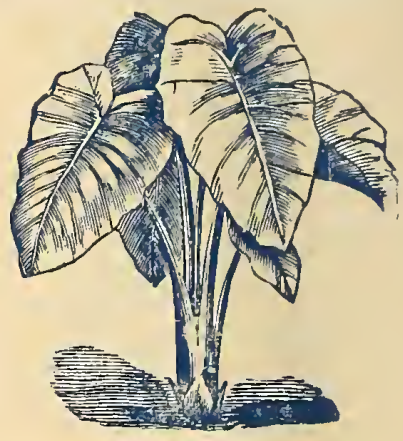

CALADTUM.

Or Elephant Ear. Selected. Medium size, 5c each; large size, 10c each; selected 15c each, postpaid.

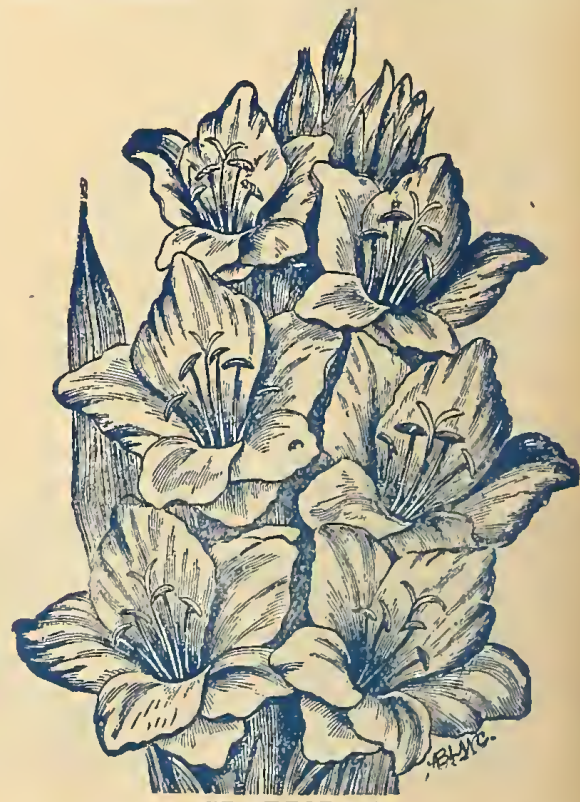

GLADIOLAS.

American Pink and Lavender, Augusta Pure White, Francis King Scarlet and Crimson Bletahs Bulbs. 5c each; 1 doz. $50 \mathrm{c}$, postpaid. 


\section{B U L B S}

CANNAS AND DAHI.IAS.

We are large growers of those Bulbs and have a large quantity of the most valuable sorts, and you will find that our prices are the lowest QUOTED BY ANY SEED HOUSE. PRICE, PER SINGLE BULB, 10c; 3 for $25 \mathrm{c}$; 6 for $35 \mathrm{c}$, and one dozen nicely packed in box, postpaid. $60 \mathrm{c}$. Make your own selection, any varieties you want. Varieties and descriptions as follows:

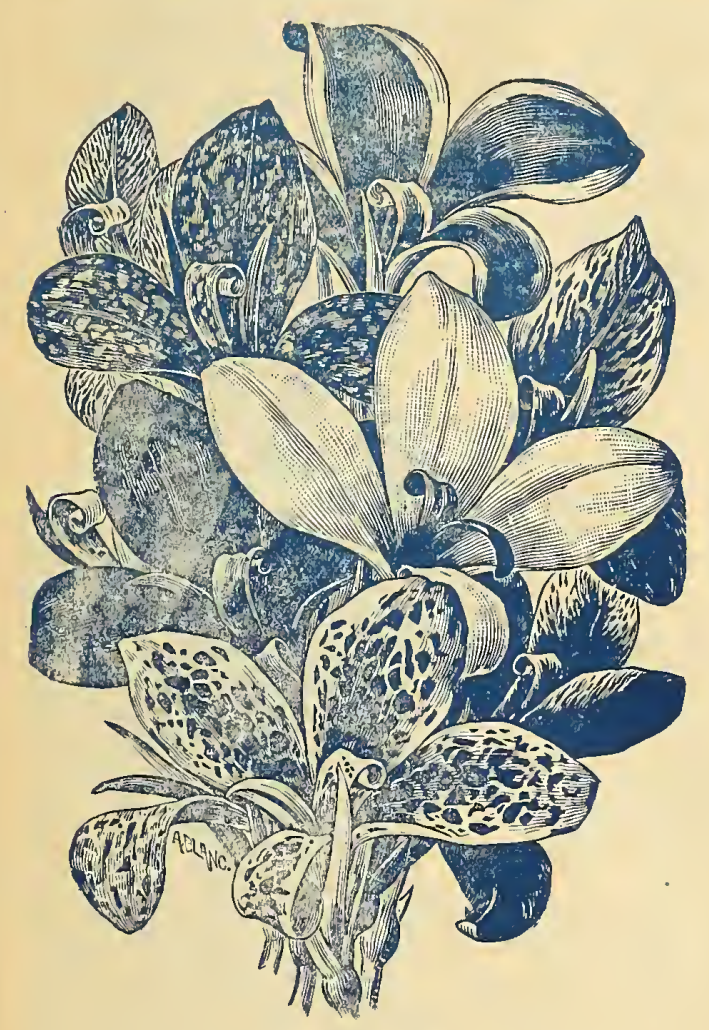

IOUISIANA.

Height 6 feet, orchid flowering vivid scarlet, green foliage.

\section{ITALIA.}

Height 4 feet, golden orange, scarlet and red, green foliage.

\section{HALEY COMET.}

New. Height 3 feet, scarlet flowers, with yellow thoat, green foliage.
WYOMING.

Height 6 feet, rich orange flowers, bronge foliage. INDIANA.

Height 6 feet, large orange flowers, green foliage. GUSTAVE GUMPER.

Height 4 feet, large yellow flowers, green foliage. NIAGARA.

Height 3 feet, crimson, with yellow border, green foliage.

\section{PENNSYLVANIA.}

Height 5 feet, scarlet, large flowering green foliage.

\section{GLADIOFLORA.}

Height 4 feet, red with yellow shading green

\section{KING HUMBERT.}

Height 4 feet, orange-scarlet with red markings, bronze foliage.

RICHARD WAI.LACE.

Height feet, canary yellow, green foliage. JEAN TISSOT.

Height 3 feet, brilliant vermillion, orange shading, green foliage.

ge pink, green foliage.

\section{AUSTRIA.}

Height 6 feet, canary yellow, red spotted, green foliage.

\section{BLACK PRINCE.}

Height 5 feet, flowers of intense deep velvet maroon, green foliage.

\section{DR. ROBERT FUNK.}

Height 4 feet, bright scarlet flowers in large cluster, green folilage.

\section{VENUS}

New. Height 4 feet, gray rosy pink, yellow border, green foliage.

\section{MONT BLANC.}

Height 3 feet, almost pure white, green foliage. FLORENCE VAUGHN.

Height $4 \frac{1}{2}$ feet, yellow dotted with red, green foliage.

\section{BURBANK.}

Height 5 feet, clear yellow, green foliage. MRS. KATE GRAY.

Scarlet and yellow, 6 feet, green foliage.

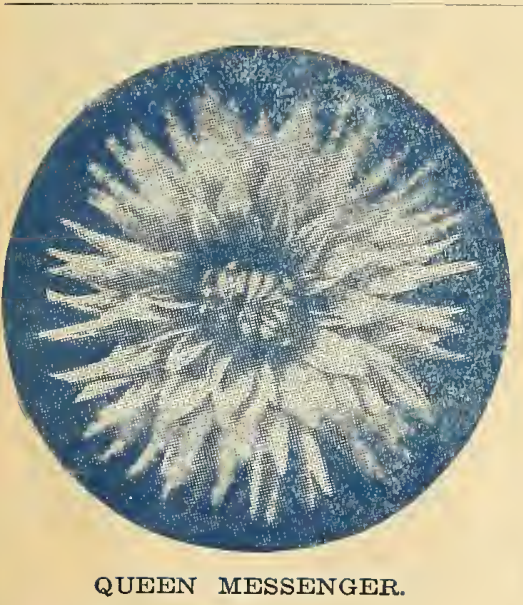

\section{DA H L I A S}

Make your own selection of this GRAND COLLECTION. 1 bulb. $10 \mathrm{c}$; 3 for $25 \mathrm{c} ; 6$ for $40 \mathrm{c}$; 12 for $70 \mathrm{c}$, all postpaid.

\section{AREBELLA (SHOW).}

Large, perfect flower. Lemon shading to primrose at tips. QUEEN MESSENGER (SHOW DAHLIA).

Large clear pink, quilled petals, large flowering.

\section{IYNDHURST.}

One of the best. Bright scarlet; perfect flowers with long stems, borne well above the foliage.

\section{JEANNE CHARMET.}

A new decorative variety of exquisite form and color. Flowers are very large and stems exceptionally long. Color a shading pink lilac, each petal edged with white. Very fine. 


\section{Dahlias-.--Continued}

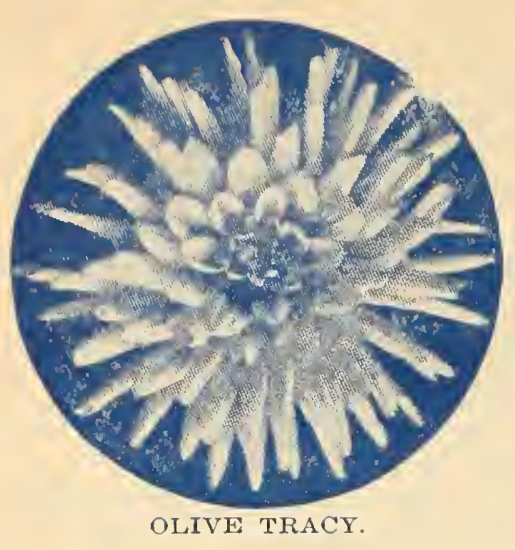

\section{CORONA (THE CARNATION DAHLIA).}

A miniature dccorative form, fully double and of nurest white. Its wonderful freedom of bloom, purc color and chaste form places it at once at the head of the list as a florist's flower. $A t$ a little distance it would bc pronounced a carnation, which it resembles both in size and form.

\section{JACK ROSE (DECORATIVE).}

Very large flat flower; full to the center. Brilliant crimson. A derful lasting qualities. Desirable for exhibition purposes.

\section{OLIVE TRACY (CACTUS).}

Clear canary yellow, a delicate color, produced on long stems, making it a valuable variety for cutting. A very attractive flower.

\section{COUNTESS OF LONSDALE (CACTUS).}

A peculiar but pleasing blending of salmon-pink and amber, early, and one of the very best, blooms freely under all conditions.

SOUVENIR-DE GUSTAVE-DOZAON (DECORATIVE).

Mammoth flowering, yellow, shading to red center.

\section{PRINCESS JULIAN (PEONY FLOWERED).}

Pure white, large flowering, very fine.

\section{SYLVIA.}

Flowers from 4 to 6 inches in diameter; of fine form and full to the center. White shaded to soft pink on the outer petals. Early and free-blooming.

\section{W. BRUTON (DECORATIVE).}

Pure yellow, very large and fine flowering.

UNCLE TOM, OR KNIGHT (CACTUS).

Dark maroon, almost black, fine flowering.

PROF, MANSFIELD (DECORATIVE).

Yellow, bronze, red shaciing, large flowering. COUNTRY GIRL (CACTUS).

Base of petals golden yellow suffused with salmon rose, a bright and pleasant combination of color, difficult to describe. Flowers very large and perfect in form.

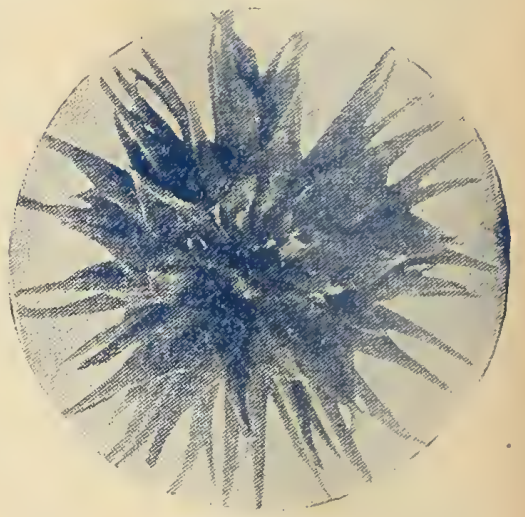

UNCLE TOM.

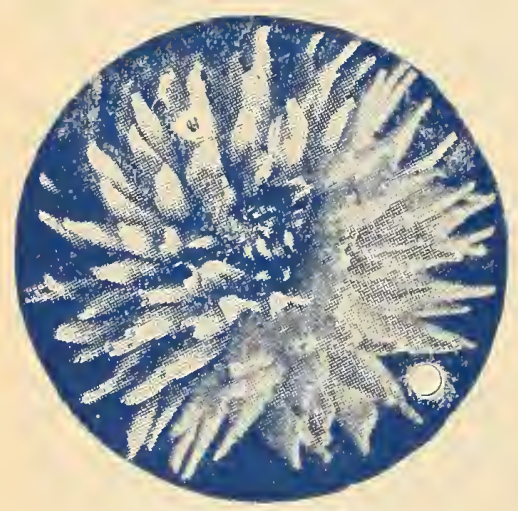

COUNTRY GIRL.

FLORAL PARK JEWEL. color

Rich purple red, tipped and striped with white. Sometimes solid A. D. LIVONI.

Beautiful clear pink, quilled petals. The best pin kshow variety. A splendid cut flower. (Show). VUETONIA.

A fine show variety with quilled petals and handsomely formed flowers. Tall grower. Canary yellow. (Show).

\section{DELICE (DECORATIVE).}

This Dahlia attained a world-wide popularity in the last year. In color it is a beautiful shade of rosy pink, suffused with lavender-pink. The flowers are medium size, of perfect form, and are produced in profusion on long stems well above the foliage. This variety should appeal to every lover of flowers on account of its delicate color.

\section{GAIETY.}

A superb new decorative, vivid scarlet, heavily marked with pure white. It is a variety far above the average of the fancy type. It proved an excellent cut flower varicty during the past season. Steme are long and flowers the produced freely.

TWENTIETH CENTURY.

Very large rosy-crimson, with white tips and white disc around the yellow center.

CALIFORNIA (SHOW).

Bright golden yellow, very double free blooming.

ALLRIGHT (CACTUS).

A fiery red, very early free blooming.

PINK CENTURY (SINGLE).

Beautiful single pint.

COQUETT (SHOW).

Red and white, double fine flowering.

JAMAICA (SHOW).

Deep rich purple quilled petals, very fine.

PROGRESS (SHOW).

Clear, soft rosy lake, beautifully penciled and spotted crimson. MISS MINNIE McCULLOUGH.

Soft yellow, overlaid with bronze. Valuable for use under artificial light. One of the best varieties for cut flowers.

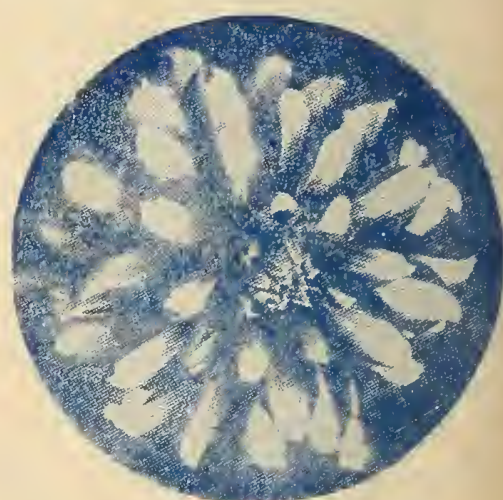

GAIETY (DECORATIVE). 


\section{GRASS AND FIELD SEEDS}

All our Seeds are of extra heary quality, re-cleaned, and prices are, including packages, subject to mar. ket change. Samples and spoclal price on application.

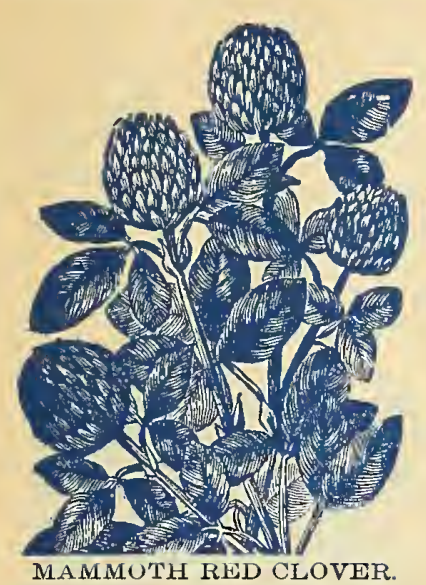

MAMMUTH RED CLOVER.

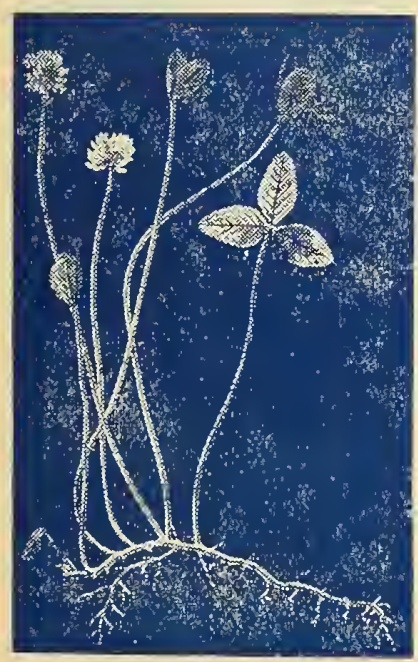

WHITE CLOVER.

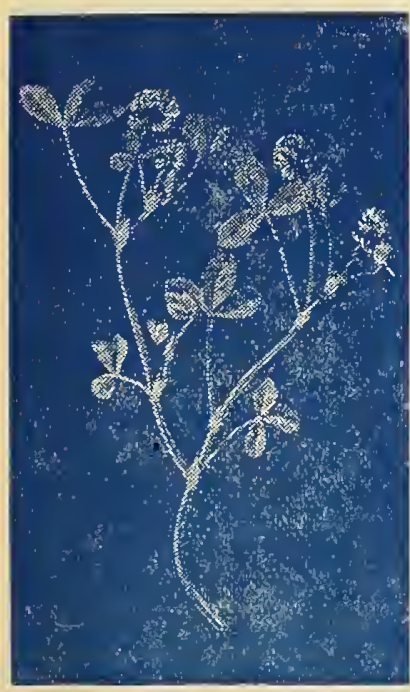

ALSIKE CLOVER.

\section{ALFALFA.}

Extra Fancy, per bu., $\$ 9.60$; per 100 lbs., $\$ 15.00$.

Fancy, per bu., $\$ 9.00$; per 100 lbs., $\$ 14.50$. Choice, per bu., $\$ 7.00$; per 100 lbs., $\$ 11.00$

\section{RED CLOVER.}

Extra Fancy, per bu., $\$ 12.00$; per 100 lbs.. $\$ 19.50$.

Fancy, per bu., \$11.50; per 100 lbs., \$18.75. Choice, per bu., $\$ 9.60$; per 100 lbs., $\$ 15.50$.

\section{MAMMOTH RED CLOVER.}

Extra Fancy, per bu., $\$ 12.00$; per 100 lbs., $\$ 19.50$.

Choice, per bu., $\$ 11.50$; per 100 lbs., $\$ 18.75$

Choice, per bu., $\$ 10.00$; per $100 \mathrm{lbs}$., $\$ 16.50$.

\section{WHITE CLOVER (DUTCH).}

For Pastures or Lawn Purposes.

Extra Fancy, per 1 b., $45 \mathrm{c}$; per bu., $\$ 24.00$. Fancy, per lb., 40c; per bu., $\$ 21.00$.

SWEET CLOVER (BOKHARA), WHITE BLOOM.

Fancy Hulled, per bu., $\$ 9.50$; per 100 lbs., $\$ 16.00$.

Fancy Unhulled, per 1b., 10c.

Fancy Yellow Bloom, per lb., 14c.

\section{ALSIKE CLOVER.}

Extra Fancy, per 1b., 20c.

Fancy, per 1b., 19c.

\section{CRIMSON CLOVER.}

Fancy, per lb., 16c.

\section{GRASS SEEDS.}

Kentucky Blue Grass.

Extra Fancy, per lb., 20c; per bu., \$2.50. Choice, per lb., 18c; per bu., \$2.25.

\section{English Blue Grass.}

Fancy, per 1b., 12c; per 100 1bs., $\$ 10.00$.

\section{Orchard Grass.}

Fancy, per 1b., 20c; per 100 lbs., $\$ 18.50$.

Bromus Inermis (or Hungarian Brome Grass.

Fancy, per lb., 15c; per 100 lbs., $\$ 13.50$. Red Top.

Fancy, per 1b., 15c; per 100 lbs., $\$ 13.50$. TIMOTHY.

Extra Fancy, per bu., \$3.10; per $100 \mathrm{lbs}$., $\$ 7.00$.

Fancy, per bu., $\$ 3.00$; per 100 lbs., $\$ 6.75$.

Choice, per bu., $\$ 2.70$; per 100 lbs., $\$ 6.00$.

\section{MILLET.}

Fancy Large German, per bu., \$2.00; per 100 lbs., $\$ 3.75$.

Choice Large German, per bu., \$1.75; per 100 lbs., $\$ 3.25$.

Fancy Common, per bu., \$2.00; per $100 \mathrm{lbs}$., $\$ 3.75$.

Choice Common, per bu., \$1.75; per $100 \mathrm{lbs}$., $\$ 3.25$.

Fancy Siberian, per bu., $\$ 1.50$; per 100 lbs., $\$ 3.00$.

\section{SUDAN GRASS.}

We have an excellent quality and it will please you in results. If you have never tried this grass, by all means do so this season.
Fancy seed, per lb., $40 \mathrm{c}$; per 100 lbs., $\$ 35.00$.

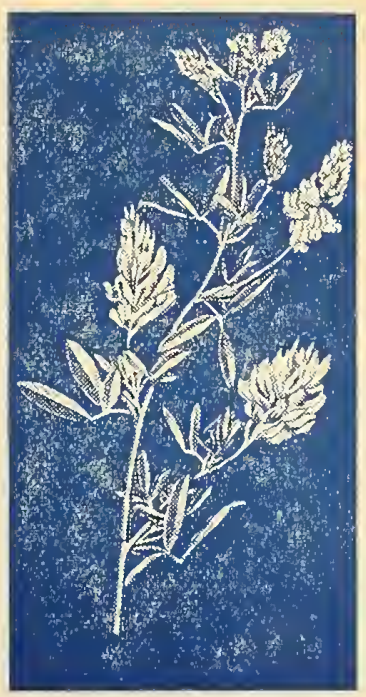

ALFALFA.

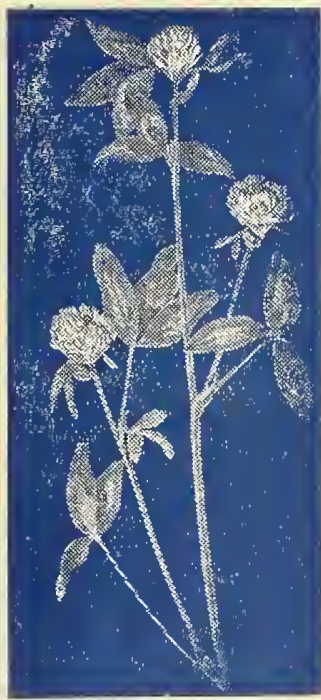

RED CLOVER.

The Rittenhouse SEEDERS

$\$ 1.25$ to $\$ 1.75$ each

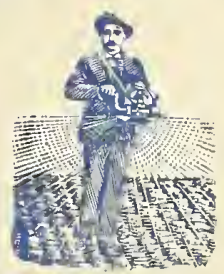

The Rittenhouse Seeder is famous for its saving qualities time, work and seed. 


\section{Field Seeds--.-Continued}

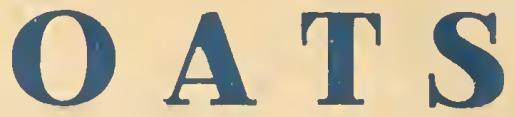

We offer you several varieties of SEED OATS, and make you prices on RE-CLEANED Select and Graded Stock. Do not think that you can buy common oats on the market and get selected Oats, for seed purposes.

GENUINE RED TEXAS, Selected, per bu.. 85c; 25 bu. lots, $80 \mathrm{c}$.

RED TEXAS OATS, Kansas grown, per bu., $75 \mathrm{c} ; 25$ bu. lots, $70 \mathrm{c}$.

Nebraska White Oats, Nebraska grown, per bu., $80 \mathrm{c} ; 25$ bu. lots, $75 \mathrm{c}$.

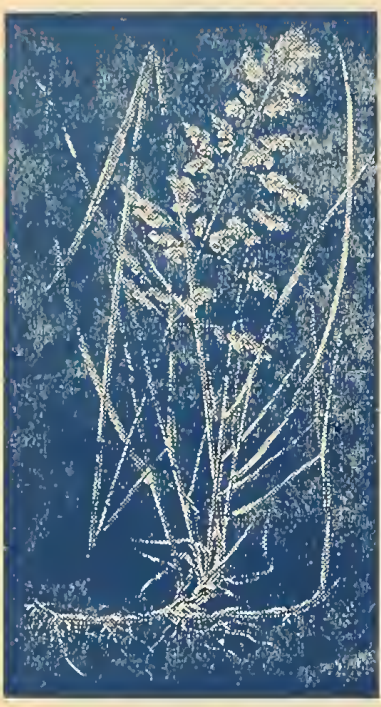

KENTUCKY BLUE GRASS.

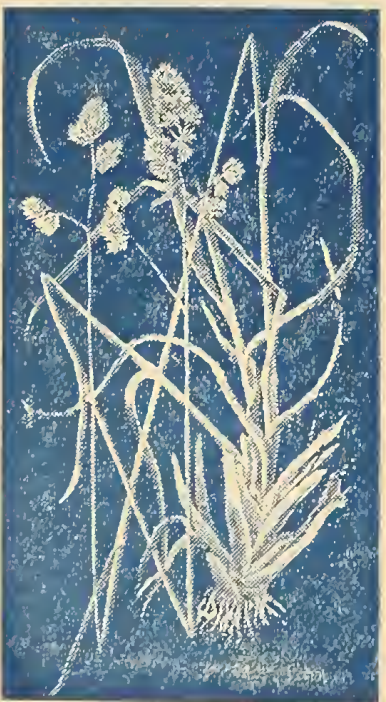

ORCHARD GRASS.
SPELTZ.

Fancy, per bu., $\$ 1.60$.

\section{EMMER}

Fancy, per bu., $\$ 1.60$.

CASTOR BEANS.

Per 1b., 10c.

DWARF ESSEX RAPE.

Per lb., $10 \mathrm{c}$; per 100 lbs., $\$ 8.00$.

\section{TEOSINTE}

Fancy Georgian, per lb., $60 \mathrm{c}$.

PEANUTS.

Jumbo, per 1b., 8c; postpaid 18c. Spanish, per lb., 8c; postpaid $18 \mathrm{c}$ Carolina, per 1b., 8c; postpaid 18c.

\section{SAND VETCH.}

Fancy, per lb., 20c; per 100 lbs., $\$ 18.00$

\section{SPRING VETCH.}

Fancy, per lb., 18c; per 100 lbs., $\$ 14.00$.

\section{PENCELARIA.}

Billion Dollar Grass, per 1b. 12c; per bu. $\$ 7.00$.

\section{RYE.}

Fancy, per bu., \$1.50.

\section{BUCKWHEAT}

Japanese Fancy, per bu., $\$ 2.00$.

Silver Hull, Fancy, per bu., $\$ 2.00$. FETERITA.

Fancy, per 100 lbs., $\$ 5.50$.

\section{JERUSALEM CORN.}

Fancy, per 100 lbs., $\$ 5.50$.

\section{BROWN DOURRHA.}

Fancy, per 100 lbs., $\$ 5.50$

MILO MAIZE (YELLOW).

Fancy, per 100 lbs., $\$ 3.50$

MILO MAIZE (WHITE).

Fancy White, per 100 lbs, $\$ 4.00$.
TIMOTHY
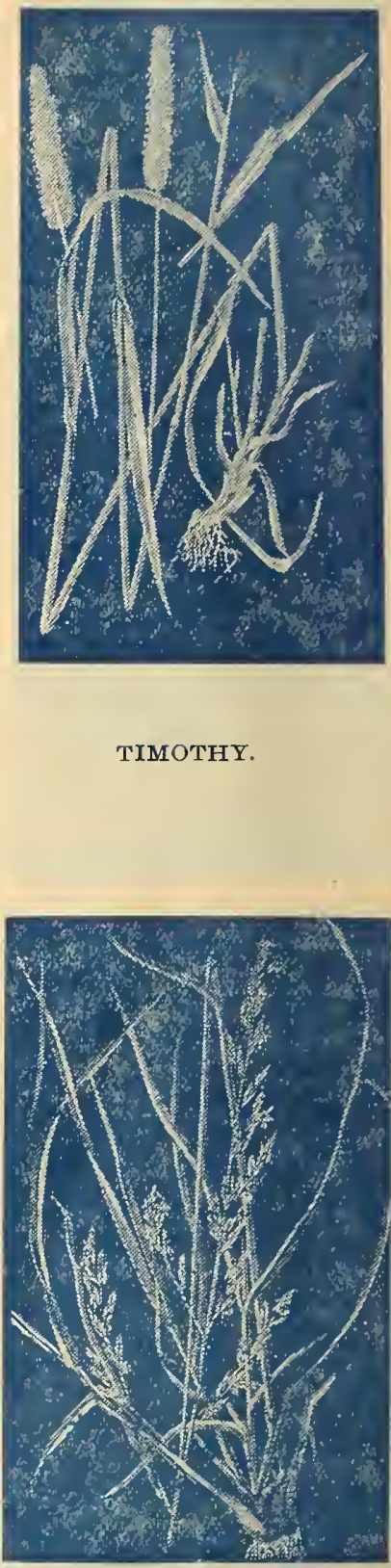

ENGLISH BLUE GRASS. (Meadow Fescue.) 


\section{Field Seeds=-=Continued}

\section{BROOM CORN.}

California Golden, per 100 lbs., $\$ 4.50$.

Olklahoma Dwarf, per 100 lbs., $\$ 4.50$.

Evergreen, per 100 lbs., $\$ 4.50$.

Japanese Dwarf, per 100 lbs., $\$ 4.50$.

FLAX SEED.

Fancy, per 1b., 8c; per 100 lbs., $\$ 7.00$

\section{BARLEYS.}

Six Rowed, per bu., $\$ 1.40$.

White Hulless, per bu., $\$ 2.50$.

Champion Beardless, per bu., $\$ 1.65$.

\section{WHEAT.}

Write for Prices.

Marconi, Fancy, per bu., .....

Red Russian, Fancy, per bu., .....

Turkey Red, Fancy, per bu., .....

Harvest Queen, per bu., .....

Fultz, Fancy, per bu., ....
HEIMP.

Fancy, per 1b., 10c; per 100 lbs., $\$ 9.00$

SUNFLOWER SEEDS.

Fancy, per 1b., 10c; per 100 lbs., $\$ 6.00$

\section{COW PEAS.}

Fancy New Era, per bu., \$3.25.

Fancy Whipporwill, per bu., \$3.25.

Fancy Clays, per bu., $\$ 3.25$.

Fancy Black Eyed, per bu., $\$ 4.00$.

Fancy Black, per bu., $\$ 4.00$.

Fancy Red Riper, per bu., $\$ 4.00$

Fancy, per 1b., postpaid, $15 \mathrm{c}$.

\section{We Buy Second Hand Sacks and Bags}

\section{And Pay As Follows:}

Sacks free from holes, sugar sacks, 3c.

Sacks with small holes, 1c to 2c each, owing to $\mathrm{c}$. lition.

Sacks holding 2 bu. or larger up to bran sacks (jute), free from holes, $5 \mathrm{c}$; with small holes, $2 \mathrm{c}$ to $3 \mathrm{c}$ each, owing to condition.

Oil meal sacks from $2 \mathrm{c}$ to $5 \mathrm{c}$ each, owing to condition.

White cotton bran sacks, $3 c$ each.

Good second-hand cotton grain bags, $10 \mathrm{c}$ to $15 \mathrm{c}$ each.

We will take all you have. Send them in by freight and we will remit full value for them soon as received.

\section{Poultry Supplies and Fertilizers}

Fine Poultry Bone, per 100 lbs........... $\$ 3.00$

Coarse Poultry Bone, per 100 lbs........... 3.00

Ground Dried Blood, per 100 lbs........... 4.00

Mica Grit Pigeon, per 100 lbs.............. .85

Mica Grit Chicken, per 100 lbs............. .85

Mica Grit Hen, per 100 lbs.............. .85

Crys-co Chick Grit, per 100 lbs............. .75

Crys-co Hen Grit, per 100 lbs................. .75

Fine Charcoal, per $100 \mathrm{lbs} . \ldots \ldots \ldots \ldots \ldots \ldots .2 .50$

Coarse Charcoal, per $100 \mathrm{lbs} . \ldots \ldots \ldots \ldots \ldots .2 .50$

Ground Clam Shells, per 100 1bs..............65

Ground Oyster Shells, per 100 lbs........... .80

Coarse Meat Scraps, per 100 lbs........... 4.00

Pulverized Sheep Manure, per 100 lbs......... 1.65

Fine Ground Beef Bone Fertilizer, per $100 \mathrm{lbs} . .22 .00$

Swift's Truck Fertilizer, per 100 lbs........ 2.00
LEE'S FYLO-CURO

Protects stock from flies, mosquitos and all insects. Quart, $35 \mathrm{c} ; 1 / 2$ gallon, $60 \mathrm{c}$; gallon, $\$ 1.00$.

\section{LEE'S LICE KILLER}

It never fails. Just spray the roosts and nests and all lice and mites will disappear. No handling of fowls, no dusting, dipping or greasing. Is all over in the average poultry house in 10 minutes. Quart can, 35c; 1/2 gallon, 60c; gallon, $\$ 1.00$. One gallon by express, prepaid, $\$ 1.25$.

Louse powder, per $1 / 4$ lb. pkg., $25 \mathrm{c}$.

Lee's Germazone, per 4 oz. bottle, $25 \mathrm{c}$. 


\section{Hayes Seed House Order Sheet}

\section{TOPEKA, KANSAS, U. S. A.}

Date

Name Write your name plain and distinct.

Amount Enclosed

P. O. order...\$

Postoffice

R. F. D.

Express order \$

State

Cash - \$

Name of Railroad

Draft

State whether by Mail, Express or Freight.

Stamps

$\$$

Send this Order by

NAME OF SEEDS WANTED

PRICE

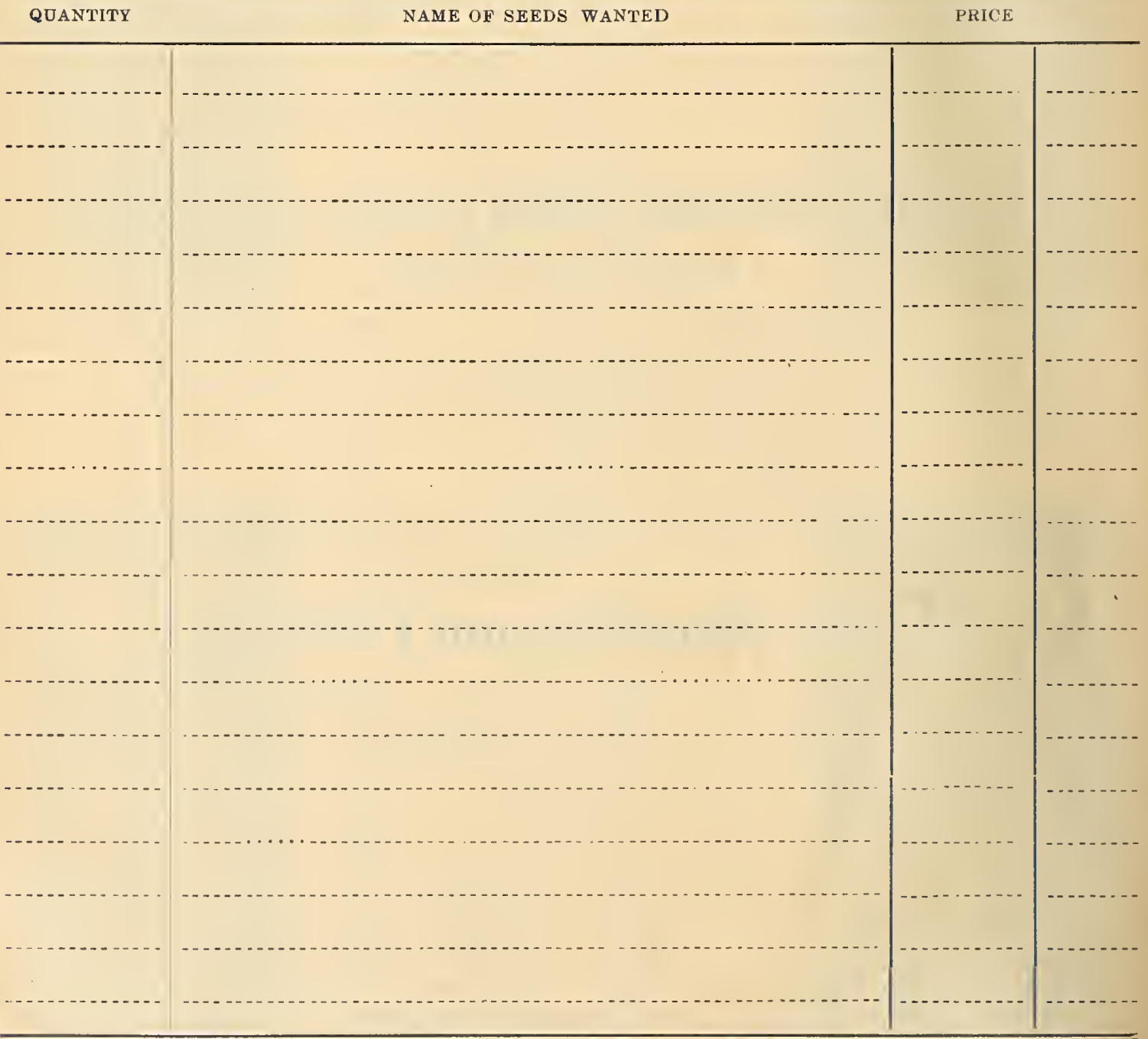




\section{PLANET JR. GARDEN TOOLS.}

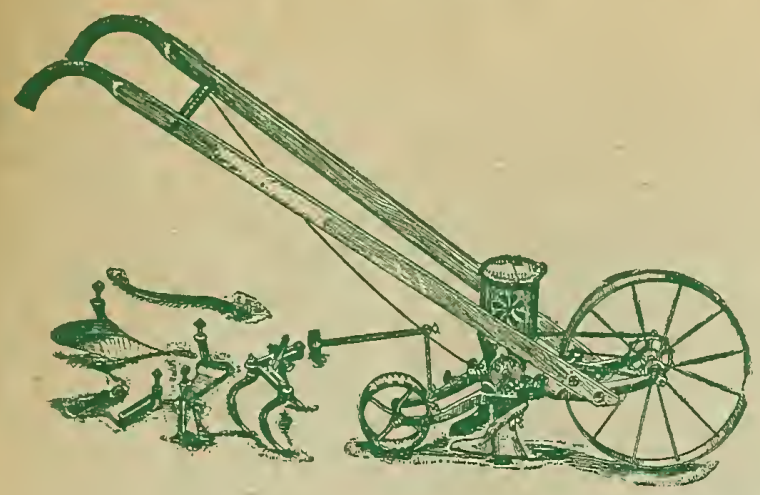

\section{The Kant Klog Sprayer.}

Hand Cultivators and Seeders have become a garden necessity. One man with a hand cultivator can do the work of six and do it easier. All are good, but some are goore adaptable for all purposes.

Space will not permit a detailed description of all the garden tools we offer, but a short reference to each will suffice to let you know what we have. and if interested. please write for spe please write for spetailed description of what you want.

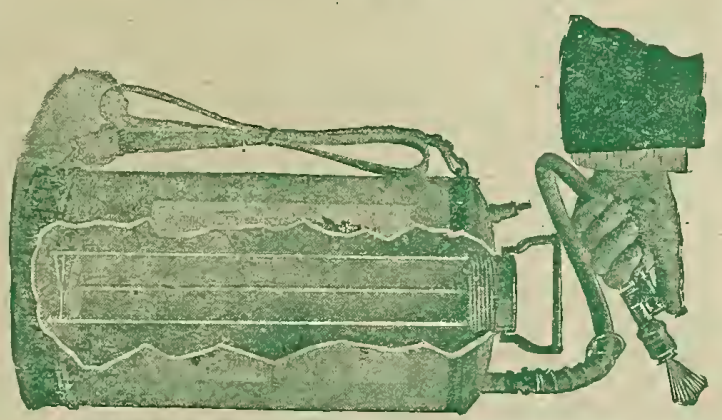

SPRAYERS

Sprays Trees, all kinds of Small Truits and Garclen Vegetables, Disinfectants, Whitewash and many other uses. Price, each, $\$ 5.00$.

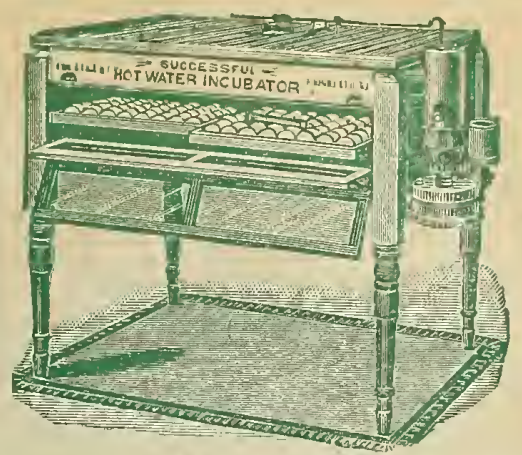

Send for our catalogue on Buckeye Incubators and Brooders.

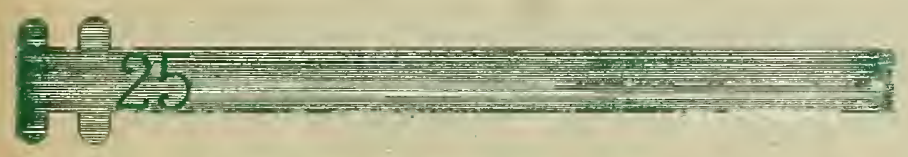

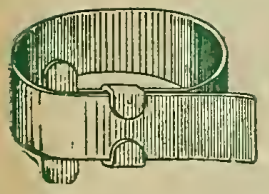

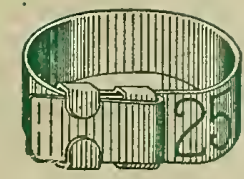

\section{ATOMIZER.}

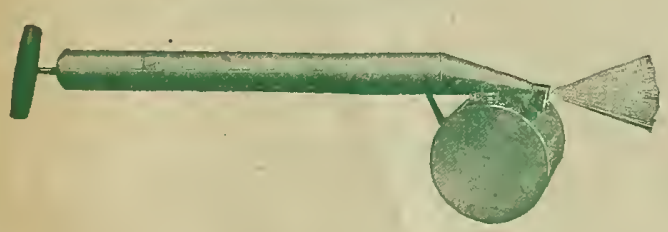

Price, capacity one quart, postpaid........\$ $\$ 0.40$

Price, capacity one pint, postpaid............35

Has tin pump barrel one and three-quarter inches in diameter. Heavy plunger rod. Screw cap filler. Does not tip over when set down.

Liquid tanlss of tin, galvanized.
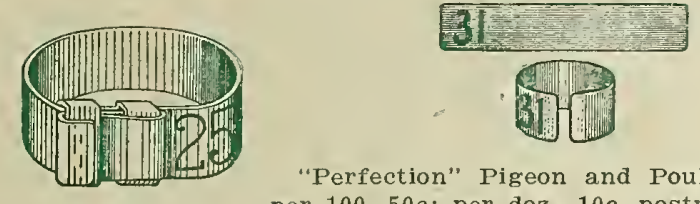

"Perfection" Pigeon and Poultry Bands, per 100, 50c; per doz., $10 \mathrm{c}$, postpaid.

\section{CONKEY'S POULTRY REMIEDIES.}

Fach Article Must Satisfy You or You Recelve Your Money Bacl.

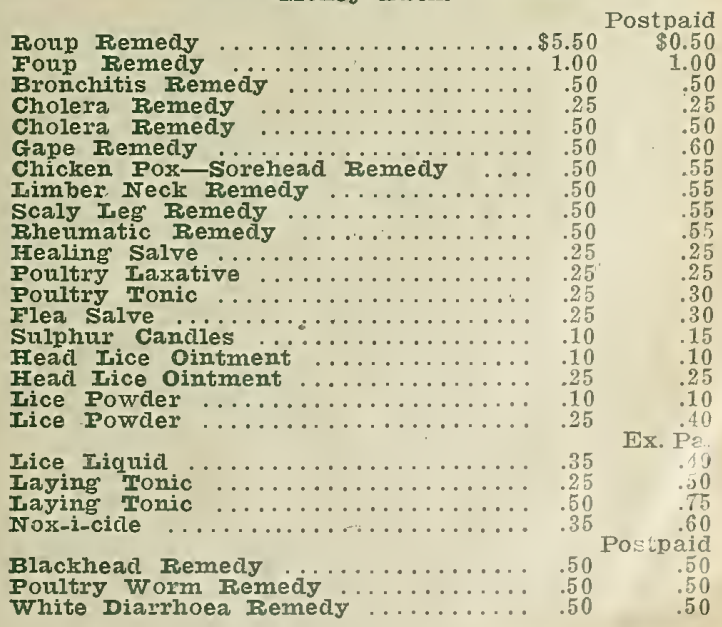


ᄋ

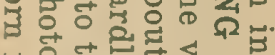

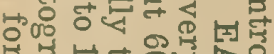

भौ

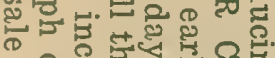

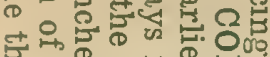

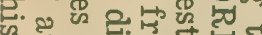
n (1)

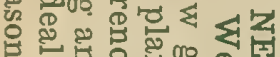

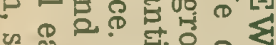
थ

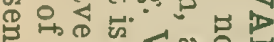

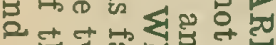

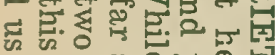

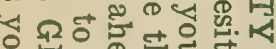

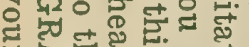

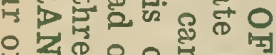

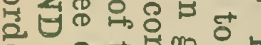

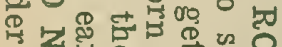

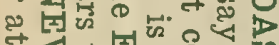
से

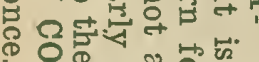
ton

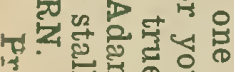

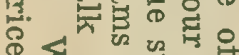
'ठ स्व

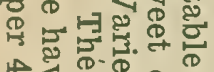

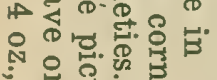
1 它 융

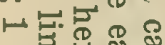

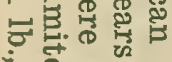
ง苋告

잉

․ㅛ용

它总的号

to क्ष

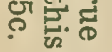

in 욜 'క ․․․

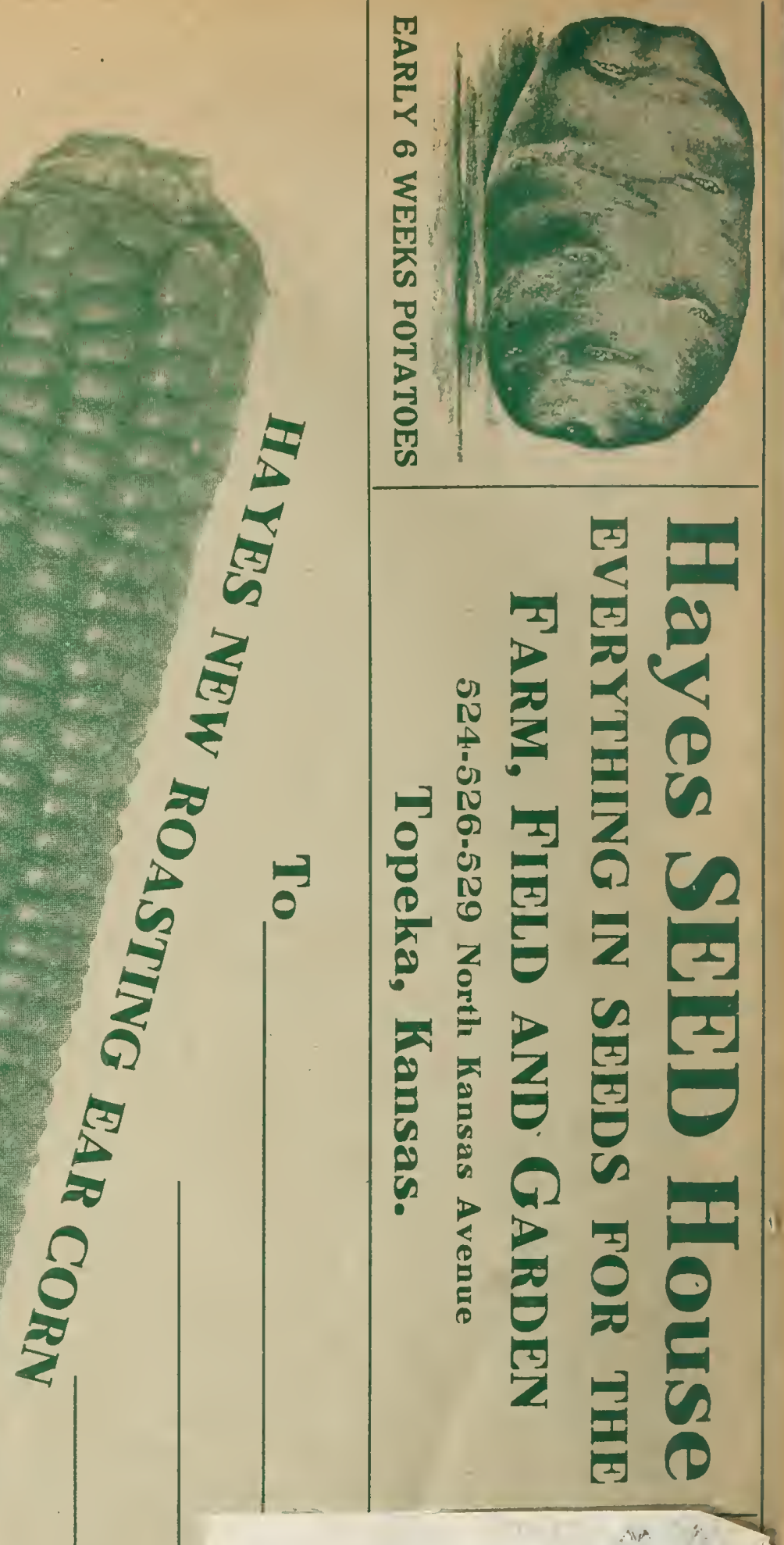

$208 z-8$

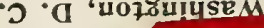

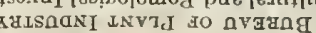

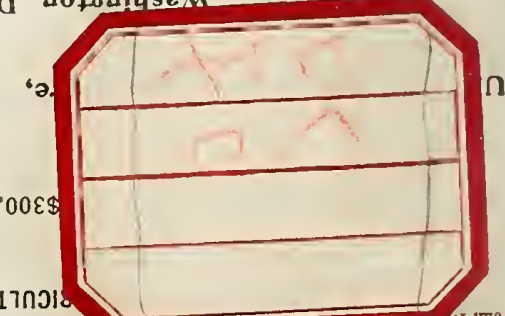

